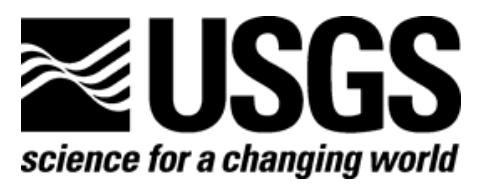

\title{
Selenium Concentrations in Middle Pennsylvanian Coal-Bearing Strata in the Central Appalachian Basin
}

By Sandra G. Neuzil, Frank T. Dulong, C. Blaine Cecil, Nick Fedorko, John J. Renton, and D. K. Bhumbla

Open-File Report 2007-1090 


\section{U.S. Department of the Interior DIRK KEMPTHORNE, Secretary}

\section{U.S. Geological Survey \\ Mark D. Myers, Director}

U.S. Geological Survey, Reston, Virginia 2007

Revised and reprinted: 2007

For product and ordering information:

World Wide Web: http://www.usgs.gov/pubprod

Telephone: 1-888-ASK-USGS

For more information on the USGS - the Federal source for science about the Earth, its natural and living resources, natural hazards, and the environment:

World Wide Web: http://www.usgs.gov

Telephone: 1-888-ASK-USGS

Suggested citation:

Neuzil, S.G., Dulong, F.T., Cecil, C.B., Fedorko, N., Renton, J.J., and Bhumbla, D.K., 2007, Selenium concentrations in Middle Pennsylvanian coal-bearing strata in the central Appalachian basin: U.S. Geological Survey Open-File Report 2007-1090.

Any use of trade, product, or firm names is for descriptive purposes only and does not imply endorsement by the U.S. Government.

Although this report is in the public domain, permission must be secured from the individual copyright owners to reproduce any copyrighted material contained within this report. 


\section{Contents}

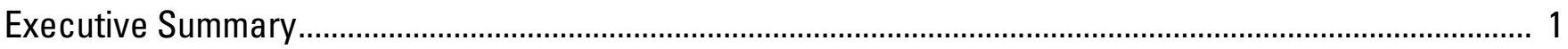

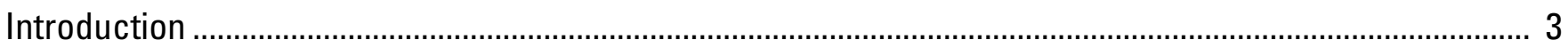

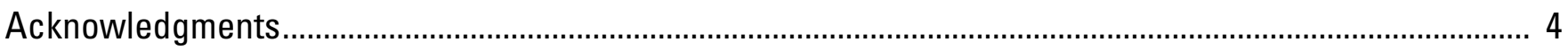

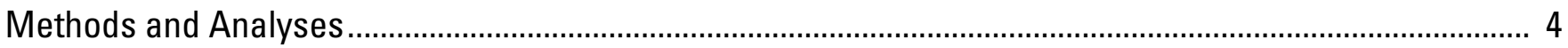

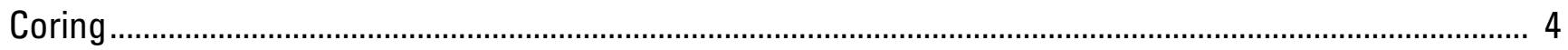

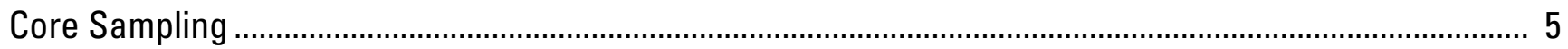

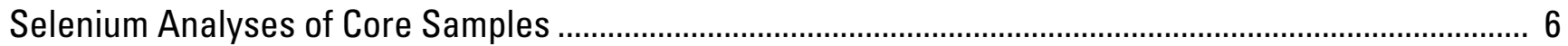

Analyses of Core Samples for Mineralogy and Major Element Oxides..................................................... 6

Analyses of Total Sulfur and Loss on Ignition in Coal-Bed Roof, Parting, and Floor Samples.................... 7

Leach Tests: Saturated Paste Extract (SPE) and Sequential Water Extraction (SWE) .............................. 7

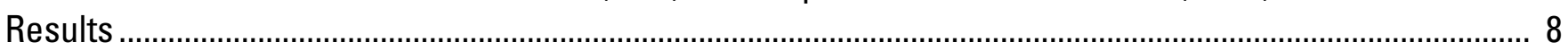

Estimates of Analytical Precision ............................................................................................................. 8

Core Comparisons: A Test for Spatial Variation in Selenium Concentrations in Middle Pennsylvanian

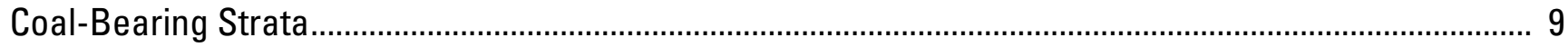

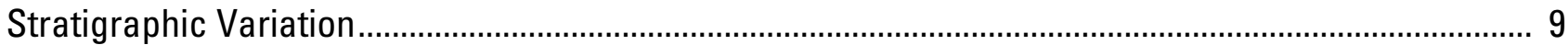

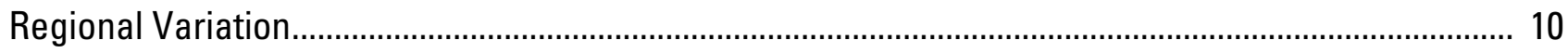

Frequency Distribution of Selenium Concentrations in Three Cores...................................................... 10

Selenium Concentrations and Dominant Lithologies (Rock Types).......................................................... 10

Selenium Concentrations in Roof, Parting, and Floor Samples............................................................ 11

Relation Between Selenium, Mineralogy, and Major Element Oxides Concentrations ........................... 11

Sulfur, Loss on Ignition, and Selenium in Roof, Parting, and Floor Samples .......................................... 12

Aqueous Extraction of Soluble Selenium ........................................................................................ 12

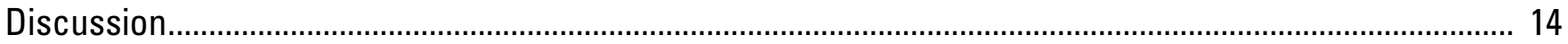

Selenium Concentration, Lithology, and Mineralogy …….................................................................. 14

Comparison of Se Concentrations in Roof, Parting, Floor, and Four Dominant Lithologies...................... 15

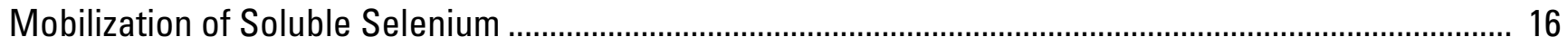

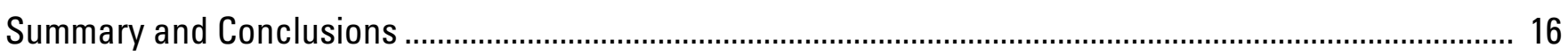

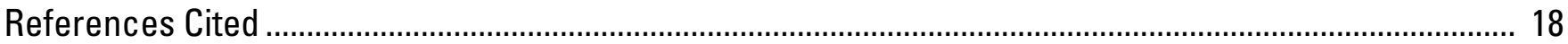

Appendix A1. Coal bed stratigraphy in core USGS 9

Appendix A2. Coal bed stratigraphy in core USGS 11

Appendix A3. Coal bed stratigraphy in core USGS 12

Appendix A4. Lithology terminology and abbreviations used by the West Virginia Geological and

Economic Survey for core description

Appendix A5. Geologists' description of core USGS 9

Appendix A6. Geologists' descriptions of core USGS 11

Appendix A7. Geologists' descriptions of core USGS 12

Appendix A8. Natural gamma ray, density, resistivity and caliper logs for core USGS 9

Appendix A9. Natural gamma ray, density, resistivity and caliper logs for core USGS 11

Appendix A10. Natural gamma ray, density, resistivity and caliper logs for core USGS 12

Appendix B1. Se analyses of USGS 9-LITH samples, 1-foot increment samples selected by lithology from core USGS 9 
Appendix B2. Se analyses of USGS 9-10-ft samples, 1-foot increment samples collected at 10-foot intervals from core USGS 9

Appendix B3. Se analyses of USGS 11-10-ft samples, 1-foot increment samples collected at 10-foot intervals from core USGS 11

Appendix B4. Se analyses of USGS 12-10-ft samples, 1-foot increment samples collected at 10-foot intervals from core USGS 12

Appendix B5. Major phase mineralogy X-ray diffraction (XRD) and major element oxide X-ray fluorescence (XRF) analyses of USGS 9-LITH samples, 1-foot increment samples selected by lithology from core USGS 9

Appendix B6. Major phase mineralogy X-ray diffraction (XRD) and major element oxide X-ray fluorescence (XRF) analyses of USGS 9-10-ft samples, 1-foot increment samples collected at 10foot intervals from core USGS 9

Appendix B7. Major phase mineralogy X-ray diffraction (XRD) and major element oxide X-ray fluorescence (XRF) analyses of USGS 11-10-ft samples, 1-foot increment samples collected at 10foot intervals from core USGS 11

Appendix B8. Major phase mineralogy X-ray diffraction (XRD) and major element oxide X-ray fluorescence (XRF) analyses of USGS 12-10-ft samples, 1-foot increment samples collected at 10foot intervals from core USGS 12

Appendix B9. Se concentration, thickness, ash, total sulfur, and loss on ignition data for roof, parting, and floor samples from core USGS 9

Appendix B10. Se concentration in saturated paste extract leachate (SPE) and rock from USGS 9-10-ft samples, 1-foot increment samples collected at 10-foot intervals from core USGS 9

Appendix B11. Se concentration in saturated paste extract leachates from rock (SPE-A), a second extraction (SPE-B), and Se concentration in rock from USGS 11-10-ft samples, 1-foot increment samples collected at 10-foot intervals from core USGS 11

Appendix B12. Se concentration in saturated paste extract leachate (SPE) and rock from USGS 12-10-ft samples, 1-foot increment samples collected at 10-foot intervals from core USGS 12

Appendix B13. Se concentration in sequential water extraction leachate (SWE) and rock from USGS 1110-ft samples, 1-foot increment samples collected at 10-foot intervals from core USGS 11 Appendix B14. Se concentration in replicate analyses of 12 rock samples coincident to both USGS 9LITH and USGS 9-10-ft

\section{Figures}

1. Map showing the location of three widely spaced cores (USGS 9, USGS 11, and USGS 12) in West Virginia, used in this study as part of a regional study of geochemical variation in the central Appalachian basin

2. Se concentration $(\mu \mathrm{g} / \mathrm{kg}$ ) versus depth $(\mathrm{ft})$ in core USGS 9-LITH samples, 1-foot increment samples selected by lithology

3. Se concentration $(\mu \mathrm{g} / \mathrm{kg}$ ) versus depth $(\mathrm{ft})$ in core USGS 9-10-ft samples, 1-foot increment samples collected at 10 -foot intervals

4. Se concentration $(\mu \mathrm{g} / \mathrm{kg})$ versus depth (ft) in core USGS 11-10-ft samples, 1-foot increment samples

collected at 10 -foot intervals

5. Se concentration $(\mu \mathrm{g} / \mathrm{kg})$ versus depth (ft) in core USGS 12-10-ft samples, 1-foot increment samples collected at 10 -foot intervals 
6. Mean Se concentration $(\mu \mathrm{g} / \mathrm{kg}) \pm 95$ percent confidence interval (Cl 95\%) for upper and lower stratigraphic intervals in each core

7. Frequency distribution of $S e$ concentration $(\mu \mathrm{g} / \mathrm{kg})$ for all rock samples collected at 10 -foot intervals from USGS 9-10-ft, USGS 11-10-ft, and USGS 12-10-ft.

8. Mean Se concentration $(\mu \mathrm{g} / \mathrm{kg}) \pm 95$ percent confidence interval $(\mathrm{Cl} 95 \%)$ for four dominant lithologies from USGS 9-LITH and roof, parting, and floor samples from core USGS 9.

9. Mean Se concentration $(\mu \mathrm{g} / \mathrm{kg}) \pm 95$ percent confidence interval (CI $95 \%)$ for four dominant lithologies from USGS 9-10-ft and roof, parting, and floor samples from core USGS $9 .$. 28

10. Mean Se concentration $(\mu \mathrm{g} / \mathrm{kg}) \pm 95$ percent confidence interval $(\mathrm{Cl} 95 \%)$ for four dominant lithologies from USGS 9-LITH and USGS 9-RPF (combined roof, parting, and floor samples from core USGS 9)

11. Mean Se concentration $(\mu \mathrm{g} / \mathrm{kg}) \pm 95$ percent confidence interval $(\mathrm{Cl} 95 \%)$ for four dominant lithologies from USGS 9-10-ft and USGS 9-RPF (combined roof, parting, and floor samples from core USGS 9).

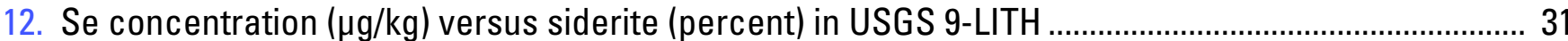

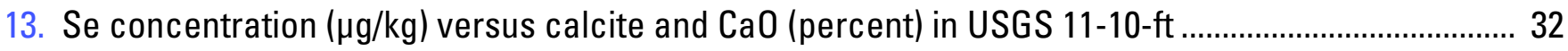

14. Se concentration $(\mu \mathrm{g} / \mathrm{kg})$ versus chlorite, kaolinite, illite, calcite, and $\mathrm{K}_{2} \mathrm{O}$ (percent) in USGS 12-10-ft 33

15. Se concentration $(\mu \mathrm{g} / \mathrm{kg}$ ) versus total sulfur (percent, dry basis) in roof, parting, and floor samples from USGS 9

16. Se concentration $(\mu \mathrm{g} / \mathrm{kg}$ ) versus loss on ignition (percent, dry basis) in roof, parting, and floor samples from USGS 9

17. Se concentration $(\mu \mathrm{g} / \mathrm{L})$ in saturated paste extract $(\mathrm{SPE})$ versus Se concentration $(\mu \mathrm{g} / \mathrm{kg})$ in rock samples from USGS 9-10-ft.

18. Se concentration $(\mu \mathrm{g} / \mathrm{L})$ in saturated paste extract (SPE-A) versus Se concentration $(\mu \mathrm{g} / \mathrm{kg})$ in rock samples from USGS 11-10-ft

19. Se concentration $(\mu \mathrm{g} / \mathrm{L})$ in saturated paste extract $(\mathrm{SPE})$ versus Se concentration $(\mu \mathrm{g} / \mathrm{kg})$ in rock samples from USGS 12-10-ft

20. Se concentration $(\mu \mathrm{g} / \mathrm{L})$ in sequential water extraction first extract $(S W E-A)$ versus Se concentration $(\mu \mathrm{g} / \mathrm{kg})$ in rock samples from USGS $11-10-\mathrm{ft}$.

21. Se concentration $(\mu \mathrm{g} / \mathrm{L})$ in sequential water extraction first extract of rock sub-sample $A(S W E-A)$ versus Se concentration $(\mu \mathrm{g} / \mathrm{L})$ in sequential water extraction first extract of rock sub-sample B (SWE-B) for USGS 11-10-ft samples

22. Se concentration $(\mu \mathrm{g} / \mathrm{L})$ in saturated paste extract (SPE-A) versus Se concentration $(\mu \mathrm{g} / \mathrm{L})$ in sequential water extraction first extract (SWE-A) for duplicate sub-samples of rock from USGS $11-10-\mathrm{ft}$

23. Absolute Se ( $\mu \mathrm{g}$ Se in solution / $\mathrm{kg}$ of rock leached) in saturated paste extract (SPE-A) versus absolute Se ( $\mu \mathrm{g}$ Se in solution / $\mathrm{kg}$ of rock leached) in sequential water extraction first extract (SWE-A) for duplicate sub-samples of rock from USGS 11-10-ft.

24. Se concentration ( $\mu \mathrm{g} / \mathrm{L}$ ) in sequential water extractions (SWE-) for up to 7 sequential extractions of a rock sample, for samples from USGS 11-10-ft. 40

\section{Tables}

1. Trace element concentrations for 13 elements, including Se, reported in ASTM 3052 with National Institute of Standards and Technology (NIST) data for standard reference material (SRM) 270441 
2. Comparison of Se concentration in 12 samples coincident to both USGS 9-LITH and USGS 9-10-ft.... 42

3. Se concentrations in duplicate samples and replicate analyses of 12 samples coincident to both USGS

9-LITH and USGS 9-10-ft

4. A test for stratigraphic variation of Se concentration, comparing the upper stratigraphic interval to the lower stratigraphic interval in each core (USGS 9-LITH, USGS 9-10-ft, USGS 11-10-ft, and USGS

12-10- $\mathrm{ft}$ ), using univariate statistics and t-test comparisons 45

5. A test for regional variation of Se concentration in each stratigraphic interval (upper and lower) compared among cores, using univariate statistics and t-test comparisons

6. Frequency distribution and univariate statistics for Se concentration data in all samples collected at 10-foot intervals in USGS 9-10-ft, USGS 11-10-ft, and USGS 12-10-ft.

7. A test for lithologic variation of Se concentration in four dominant lithologies in USGS 9-LITH and USGS 9-10-ft samples, using univariate statistics and t-test comparison

8. A test for lithologic variation of Se concentration in roof, parting, and floor samples from USGS 9 , using univariate statistics and t-test comparison.

9. Se concentration in USGS 9-RPF (combined roof, parting and floor samples from USGS 9), univariate statistics

10. A test for lithologic variation in Se concentration between USGS 9-RPF, roof, parting, and floor samples and four dominant lithologies in USGS 9-LITH and USGS 9-10-ft samples, using univariate statistics and t-test comparisons

11. Comparison of Se concentrations (ppm) in various lithologies for published data and data reported in this study 56

\section{Conversion Factors}

\section{SI to Inch/Pound}

\begin{tabular}{lcl}
\hline \multicolumn{1}{c}{ Multiply } & By & \multicolumn{1}{c}{ To obtain } \\
\hline Volume & & \\
\hline Liter (L) & 33.82 & ounce, fluid (fl. oz) \\
Liter (L) & 2.113 & pint (pt) \\
Liter (L) & 1.057 & quart (qt) \\
Liter (L) & 0.2642 & gallon (gal) \\
Liter (L) & 61.02 & cubic inch $\left(\right.$ in $\left.^{3}\right)$ \\
\hline Mass & & \\
\hline Gram (g) & 0.03527 & ounce, avoirdupois (oz) \\
Kilogram (kg) & 2.205 & pound avoirdupois (lb) \\
\hline
\end{tabular}




\title{
Selenium Concentrations in Middle Pennsylvanian Coal-Bearing Strata in the Central Appalachian Basin
}

\author{
By Sandra G. Neuzil', Frank T. Dulong', C. Blaine Cecil', Nick Fedorko², John J. Renton ${ }^{3}$, and D. K. \\ Bhumbla $^{4}$
}

\section{Executive Summary}

This report provides the results of a reconnaissance-level investigation of selenium (Se) concentrations in Middle Pennsylvanian coal-bearing strata in the central Appalachian basin. Bryant and others (2002) reported enrichments of Se concentrations in streams draining areas disturbed by surface mining relative to Se concentrations in streams that drain undisturbed areas; the study was conducted without the benefit of data on Se concentrations in coal-bearing strata prior to anthropogenic disturbance. Thus, the present study was conducted to provide data on Se concentrations in coal-bearing strata prior to land disturbance. The principal objectives of this work are: 1) determine the stratigraphic and regional distribution of Se concentrations in coalbearing strata, 2) provide reconnaissance-level information on relations, if any, between Se concentrations and lithology (rock-type), and 3) develop a cursory evaluation of the leachability of Se from disturbed strata. The results reported herein are derived from analyses of samples obtained from three widely-spaced cores that were collected from undisturbed rock within a region that has been subjected to extensive land disturbance principally by either coal mining or, to a lesser extent, highway construction. The focus was on low-organic-content lithologies, not coal, within the coalbearing interval, as these lithologies most commonly make up the fill materials after coal mining or in road construction.

The results and interpretations of the present study are summarized as follows:

- The precision of the analytical method used in this study to determine Se concentrations in rock samples is consistent with the precision as reported by ASTM (The American Society for Testing and Materials, ASTM 3052, standard method for the determination of Se in rock samples, 95 percent confidence interval $(\mathrm{CI} 95 \%)=0.9 \mu \mathrm{g} / \mathrm{g}$ at the $1 \mu \mathrm{g} / \mathrm{g}$ ( 1 part per million, ppm) level of concentration). The precision of ASTM 3052 is likely to decrease as the concentration of Se decreases below $1 \mu \mathrm{g} / \mathrm{g}$.

- The average Se concentrations in coal-bearing strata in the central Appalachian basin are similar to the average Se concentrations reported for equivalent lithologies (Horn and Adams, 1966 and references therein). Therefore, the average Se concentrations in the various

\footnotetext{
${ }^{1}$ U.S. Geological Survey, Reston, Virginia

${ }^{2}$ West Virginia Geological and Economic Survey, Morgantown, West Virginia (retired 2006)

${ }^{3}$ West Virginia University, Morgantown, West Virginia

${ }^{4}$ Consultant, Morgantown, West Virginia
} 
lithologies investigated in the present study are not anomalous when compared to values reported in the literature.

- The mean Se concentrations in the higher stratigraphic interval (Stockton A coal bed, lower Allegheny Formation, down to the Chilton A coal bed, middle Kanawha Formation) are consistently higher than the mean Se concentrations in the lower stratigraphic interval (Chilton A coal bed down to the Fire Clay coal bed in the middle Kanawha Formation) in each of the three cores that were evaluated. The apparent stratigraphic trend in Se concentrations appears to mimic the stratigraphic trend of Se concentrations in coal beds reported by Neuzil and others (2005).

- There is no demonstrable regional variation (trend) in Se concentrations.

- With the possible exception of higher Se concentration in siltstone, the mean and range of selenium concentrations is similar among four dominant lithologies (claystone, shale, siltstone, and sandstone).

- Se concentrations are not consistently correlated with a specific mineral or major element.

- Se concentrations were determined in selected coal-bed roof, parting, and floor samples from one core. The mean values of Se concentrations for each of these three types of samples are statistically equal.

- Se concentrations in the selected roof, parting and floor samples are not statistically correlated with total sulfur concentrations (a proxy for the mineral pyrite, $\mathrm{FeS}_{2}$ ). Therefore, it is unlikely that a majority of the $\mathrm{Se}$ is associated with pyrite in these samples.

- Se concentrations in the selected roof, parting, and floor samples correlate with the loss on ignition analyses (a proxy for organic matter concentrations). The loss on ignition correlation suggests that most of the Se in roof, parting, and floor samples analyzed is organically bonded. Rates of organically bonded Se dissolution are likely to be slow and are probably controlled by relatively slow rates of chemical oxidation of the host organic matter.

- Cursory leaching studies indicate that Se concentrations in rock samples are not correlated with Se concentrations in water leachates derived from splits of the same rock samples. Therefore, total Se, as determined in whole-rock samples, may not be a reliable indicator of water soluble Se. Consequently, leach testing, rather than total Se concentrations in rock, may be a more useful predictor of potential stream contamination following land disturbance.

- Although the readily soluble fraction of the total Se in coal-bearing strata is unknown, the cursory study of sequential water leaching conducted in the present investigation indicates that readily soluble Se may be rapidly removed from rock debris following disturbance of strata.

On the basis of the present study, the average concentrations of Se in Middle Pennsylvanian coal-bearing strata in the central Appalachian basin are not anomalous when compared to published values for similar rock types. In addition, the average concentrations of Se indicate that if regional trends exist, such trends are below the detection limits of the methods used in this study. Also, there is no apparent association of Se with a specific mineral or a specific rock type (claystone, shale, siltstone, or sandstone) with the possible exception of Se enrichment in certain siltstone and coal-bed roof, parting, and floor samples. Leach testing methods, rather than analyses of total Se content of rocks, may provide the most accurate assessment of the potential for Se mobilization and stream contamination as a result of land disturbance. 


\section{Introduction}

The upper limit of total Se concentration in streams recommended by EPA in order to protect aquatic life is 5 micrograms per liter $(\mu \mathrm{g} / \mathrm{L}$, parts per billion, or ppb). Bryant and others (2002) reported that concentrations of Se in streams draining areas disturbed by surface mining of coal in the central Appalachian basin were higher (median $12 \mu \mathrm{g} / \mathrm{L}$ ) in comparison to streams draining undisturbed areas (median $1.5 \mu \mathrm{g} / \mathrm{L}$ ). However, a general lack of data on Se concentrations in coal-bearing strata precluded the attribution of Se concentrations in streams to specific rock types, stratigraphic intervals, or specific areas subjected to land disturbance. To address any potential correlations between bed rock geology, dissolution of Se following land disturbance, and subsequent increases in Se concentrations in streams, the U.S. Geological Survey (USGS), in cooperation with the West Virginia Geological and Economic Survey (WVGES) and West Virginia University (WVU), initiated a study to evaluate Se concentrations in coal-bearing strata (not including the coal beds) in the central Appalachian region.

In a companion study, Neuzil and others (2005) used data from the USGS National Coal Resources Data System to evaluate Se concentrations in Pennsylvanian-age coal beds in the Appalachian region. Their study indicates that Se concentrations in Middle Pennsylvanian age coal beds (the principal stratigraphic interval of mountain-top-mining at the time of their report) are somewhat enriched in Se (median 5 ppm Se, for 737 samples) relative to older and younger coal beds (median $3 \mathrm{ppm}$ Se, for 1486 samples). The overall conclusions of the study by Neuzil and others (2005) are consistent with earlier observations by Gluskoter and others (1977) that Se is enriched in coal beds relative to host strata and relative to the average abundance of Se in the earth's crust. The average Se concentration of upper continental crust is poorly constrained. However, Rudnick and Gao (2003) suggest a value of 0.09 ppm Se based on few data.

Although Se concentrations in coal beds world wide (Yudovich and Ketris, 2006), in the United States (Coleman and others, 1993), in eastern Kentucky (Eble and Hower, 1997), and in West Virginia (WVGES, 2002) are relatively well known, systematic studies of Se in strata associated with coal beds have been minimal. Therefore, the present study was designed to develop a preliminary understanding of Se concentrations in coal-bearing strata in the central Appalachian basin. This report focuses on Middle Pennsylvanian strata where anthropogenic activities such as surface mining and highway construction have either disturbed or may disturb large volumes of rock.

The present study was undertaken to begin developing a data base that can be used in the assessment of the effects of land disturbance on Se concentrations in surface streams, as suggested by Bryant and others (2002). The current study is a first-stage in the possible development of a comprehensive data base, and as such this report is preliminary in nature. Far more data will be required in order to conduct a comprehensive assessment of Se concentrations in Pennsylvanian age coal-bearing strata, comparable to the report by Neuzil and others (2005) on Se in coal beds. The objectives of the present study were to: 1) evaluate the spatial variation of Se, in coal-bearing strata in the central Appalachian basin, 2) make a preliminary comparison of Se concentrations in coal-bearing strata of the region relative to average concentrations of Se in sedimentary strata, as reported in the literature, and 3) investigate the mobilization of Se by water from disturbed coalbearing strata. For the purposes of this report, spatial variation refers to both stratigraphic variation and regional variation of Se concentrations in coal-bearing strata. Stratigraphic trends refer to any vertical trends in Se concentrations over hundreds of feet of coal-bearing strata. Regional variation 
relates to regional trends in Se concentrations over tens to hundreds of square miles. Three widely spaced cores that were designated as USGS 9, USGS 11, and USGS 12 were collected, sampled, and the samples analyzed, as part of this regional study (fig. 1). The principal coal-bed stratigraphic intervals identified in each of the three cores are shown in Appendices A1, A2, and A3. The second objective is intended to discern if Se in the coal-bearing strata of the central Appalachian region is in any way anomalous when compared to similar sedimentary rocks. The third objective is to investigate whether there is any simple analysis that can be used to help predict any potential for elevation of Se in streams as a result of land disturbance.

\section{Acknowledgments}

We thank Arch Coal, Inc. for providing valuable assistance in the field.

\section{Methods and Analyses}

\section{Coring}

The cores discussed in this report were part of a coring program that was developed to evaluate geologic controls on mine-drainage water quality, principally acid drainage. The total coring program consisted of eleven cores collected from both the northern- and southern-coal fields of West Virginia (fig. 1). One additional core was collected from Pennsylvanian strata in the Illinois basin. The cores were designated as USGS cores and they were numbered consecutively from one (1) through twelve (12) in the order that they were drilled. Preliminary results of the larger acid drainage study can be found in Dulong and others (2002). Cores included in this report are limited to those analyzed for Se (USGS 9, USGS 11, and USGS 12). The locations of the three cores were selected to provide a cursory evaluation of spatial variations (stratigraphic and regional) of Se in Middle Pennsylvanian coal-bearing strata in the central Appalachian basin (fig. 1). All three cores intercepted a stratigraphic interval in the Middle Pennsylvanian from the base of the Stockton A coal bed in the lower Allegheny Formation to the top of the Fire Clay coal bed in the middle Kanawha Formation. All coal beds intercepted in each core are listed in Appendices A1, A2, and A3.

Cores were obtained using standard coal exploratory wireline coring methods, producing a nominal 2 inch diameter core. Professional geologists from the WVGES logged all cores in the field as they were collected. Lithology terminology and abbreviations, as used by the WVGES for lithologic descriptions, are contained in Appendix A4. Core descriptions of USGS 9, USGS 11, and USGS 12 are contained in Appendices A5, A6, and A7. In addition, the three core holes were logged using standard coal-field geophysical logging that included density and natural gamma ray logs for USGS 9 (Appendix A8), USGS 11 (Appendix A9), and USGS 12 (Appendix A10). Comparison of geophysical logs with geological logs assured the accuracy of both core recovery and depth assignments to specific stratigraphic units such as coal beds.

Each core of coal-bearing strata was boxed by the geologist on site, and then sent to the WVGES core warehouse where they were sampled for Se analyses. Cores of coal beds, including partings within the coal beds, as well as six inches of strata above and below the coal (roof-rock and floor-rock respectively) were removed from the core at the coring site, placed in core boxes, and sent to the WVGES coal laboratory for standard coal analyses. Standard coal analyses by the WVGES generally include petrography, elemental analyses, forms of sulfur, and ash content. Coal 
analyses are not considered in this report because coal is removed as part of the mining process and should not, therefore, represent a significant source of Se in disturbed areas. Occasionally isolated blocks of coal in sandstone channel complexes and strata between coal beds may be encountered and included in fill material. In the present study the roof, parting, and floor samples from USGS 9 were analyzed for total sulfur, ash content, and Se content.

\section{Core Sampling}

Costs prohibited analysis of entire cores. Therefore, sets of samples were selected from the cores to assure the following: 1) representative samples of all lithologies were analyzed, 2) samples of lithologies were random, and 3) roof, parting, and floor lithologies were adequately sampled. Four different sampling protocols were used: 1) selection of one-foot increment samples on the basis of lithology (USGS 9), 2) collection of one-foot samples every ten feet (USGS 9, USGS 11, and USGS 12), 3) collection of samples of roof, parting, and floor associated with coal-beds (USGS 9), and 4) selection of one-foot and partial-foot thick samples close to coal beds (USGS 9). The four sampling protocols were used to collect samples from core USGS 9 whereas only the second sampling protocol was used to collect samples from cores USGS 11 and USGS 12. Samples for analyses were obtained by splitting the core lengthwise with a diamond rock saw and taking the appropriate depth increment.

The first sampling method, used exclusively on core USGS 9, was based on lithologies. One hundred (100) one-foot increment samples representing the four principal lithologies of the core (9 claystone and mudstone, 20 shale, 23 siltstone, and 48 sandstone) were selected. The lithologic description of USGS 9 (Appendix A5) indicates a total thickness of $105 \mathrm{ft}$ claystone and mudstone, $235 \mathrm{ft}$ shale, $235 \mathrm{ft}$ siltstone, and $1069 \mathrm{ft}$ sandstone, or a distribution of the four lithologies of approximately $6,14,14$, and 65 percent respectively. The samples selected for lithology are referred to as lithology samples, indicated as USGS 9-LITH. This sampling method assured that representative samples of the various lithologies, in proportion similar to their abundance in the entire core, were analyzed.

The second core sampling method, which was used on all three cores, consisted of collecting a one-foot increment within each ten-foot interval of the core. These samples are referred to as increment samples, indicated as USGS 9-10-ft, USGS 11-10-ft, and USGS 12-10-ft for the three cores. This method assured randomness of sampling of each core without bias toward any parameter except depth from surface.

The third sampling method involved selection of roof samples (generally six-inch increments of strata above coal beds), parting samples (variable thicknesses of rock within coal beds), and floor samples (generally six-inch increments of strata below coal beds) from core USGS 9. These samples, collectively referred to as RPF and indicated as USGS 9-RPF, were intentionally biased toward the strata that immediately overlie, are contained within, and underlie coal beds. The RPF samples were analyzed in order to evaluate the common perception that coal bed roof, parting, and floor strata tend to be relatively enriched in Se.

The fourth sampling method selected additional samples close to coal beds in core USGS 9. Some of these samples were one foot thick (indicated as 1-ft) and some were less than one foot thick (indicated as $\mathrm{p}$-ft, for 'partial-foot'). Throughout this report the 1-ft samples selected close to coal beds, as well as the interval samples (one-foot thick sample collected in each ten-foot interval 
of the core) are included in USGS 9-10-ft. Occasionally in this report the p-ft samples are also included in USGS 9-10-ft data analyses.

\section{Selenium Analyses of Core Samples}

Each one-foot increment of core was cut longitudinally with a saw so that about one quarter of the core was removed. These quarter-core splits were reduced in size to $1 / 4$ to $1 / 2$ inch pieces with a jaw crusher. The resulting material was quartered and three parts archived in plastic sample bags. The remaining quarter was further reduced to about $1 / 8$ inch pieces with a mortar and pestle and then ground in a shatterbox pulverizer for no more than 5 minutes to a size that passed through a 60 mesh screen.

The prepared samples were submitted to the analytical laboratory in the West Virginia University, College of Agriculture, Division of Plant and Soil Sciences, where they were analyzed for Se using the graphite furnace-atomic absorption (GFAA) method, modified ASTM 3052 [D1] (ASTM Method 3052). One quarter gram (0.25 g) of sample was weighed and placed in a fluorocarbon reaction vessel with a pressure relief valve fitted with a fluorocarbon membrane. The reaction vessel could withstand a pressure of 500 PSI. The sample was then digested in 3 milliliters $(\mathrm{ml})$ of hydrofluoric acid (HF) and $9 \mathrm{ml}$ of nitric acid $\left(\mathrm{HNO}_{3}\right)$ for 10 minutes in a microwave until all material appeared to be in solution. Subsequently, the digestion liquors were treated with $25 \mathrm{ml}$ of saturated boric acid solution and then brought to $50 \mathrm{ml}$ total volume by adding distilled water. The resultant solution was then filtered through Whatman \#42 filter paper and analyzed for Se using the graphite furnace-atomic absorption spectrometer equipped with a Zeeman background correction system.

Results of the Se analyses of rock samples from all three cores are shown for USGS 9-LITH (Appendix B1), USGS 9-10-ft (Appendix B2), USGS 11-10-ft (Appendix B3), and USGS 12-10-ft (Appendix B4). Selenium determinations that were below the limits of detection $(10 \mu \mathrm{g} / \mathrm{kg}) \mathrm{were}$ reported as ND (not detected). It is a common statistical practice to assign a value equal to half the detection limit to samples with analyses below the detection limit. In this report, however, for statistical analyses of data sets and graphical illustration, ND data were assigned a value of zero (0). A third of the samples have a Se concentration greater than $1,000 \mu \mathrm{g} / \mathrm{kg}$, which is two orders of magnitude greater than the lower detection limit. Thus, whether a value of zero or a value equal to half the detection limit $(5 \mu \mathrm{g} / \mathrm{kg})$ is assigned to samples with Se concentration below the detection limit will make little difference in statistical calculations and comparisons. The difference is discussed further under the heading "Results - Frequency Distribution of Selenium Concentrations in All Cores."

\section{Analyses of Core Samples for Mineralogy and Major Element Oxides}

A semi-quantitative estimate of the major-phase mineralogy was determined by X-ray diffraction (XRD) on all one-foot increment samples at WVU laboratories. The XRD method is semi-quantitative. Low values, less than approximately 5 percent, should be used with caution. The major mineralogical phases include chlorite, kaolinite, quartz, orthoclase (feldspar), calcite, pyrite, siderite, dolomite, illite, and albite (feldspar). In addition to mineralogy, the major element oxides were determined by X-ray fluorescence (XRF) at WVU laboratories. XRF is a semiquantitative method. The major oxides include $\mathrm{MnO}, \mathrm{K} 2 \mathrm{O}, \mathrm{SiO} 2, \mathrm{Al} 2 \mathrm{O} 3, \mathrm{SO} 2, \mathrm{Fe} 2 \mathrm{O} 3, \mathrm{Na} 2 \mathrm{O}$, $\mathrm{MgO}, \mathrm{TiO} 2, \mathrm{CaO}$, and P2O5. Results for XRD mineralogy and XRF major element oxides are 
reported for USGS 9-LITH (Appendix B5), USGS 9-10-ft (Appendix B6), USGS 11-10-ft (Appendix B7), and USGS 12-10-ft (Appendix B8).

\section{Analyses of Total Sulfur and Loss on Ignition in Coal-Bed Roof, Parting, and Floor Samples}

In addition to standard coal analyses, which include total sulfur (dry basis) and ash $\left(750^{\circ} \mathrm{C}\right.$, dry basis), the roof, parting, and floor samples from USGS 9 were analyzed for Se content. Loss on ignition (LOI) was calculated from percent ash, LOI $=(100-$ percent ash $)$. Results of the analyses of roof, parting and floor samples from USGS 9 are shown in Appendix B9. Coal analyses are not considered in this report because coal is removed as part of the mining process, and should not represent a significant source of Se in disturbed areas.

\section{Leach Tests: Saturated Paste Extract (SPE) and Sequential Water Extraction (SWE)}

In addition to the analysis of total Se in selected core samples, some of the ground rock samples were analyzed for soluble Se by an adaptation of a method used in analyses of soluble salts in soils, a method known as saturated paste extract (SPE) (Rhoades, 1982). The SPE analyses were used to estimate the amount of Se that might be available for relatively rapid dissolution following land disturbance and reclamation.

The SPE Se determinations were conducted as follows on samples from USGS 9-10-ft, USGS 11-10-ft, and USGS 12-10-ft. A saturation paste of the sample was prepared by adding 11 $\mathrm{ml}$ deionized water to a 50-ml fluorocarbon centrifuge tube and then adding $30 \mathrm{~g}$ of sample. The mixture was allowed to set overnight, and then shaken for two (2) hours on a wrist-action shaker at a speed of 10. After shaking, the mixture was centrifuged at $5000 \mathrm{rpm}$ for 25 minutes in an IESCentram $\mathrm{p} 4 \mathrm{r}$ centrifuge. The liquid obtained after centrifugation was filtered through a $0.45 \mu \mathrm{m}$ cellulose nitrate membrane filter. The filtrate was analyzed for Se using the standard GFAA method on a Perkin-Elmer 4000 atomic absorption spectrophotometer. Results for the SPE leach tests are presented for USGS 9-10-ft (Appendix B10), USGS 11-10-ft (Appendix B11), and USGS 12-10-ft (Appendix B12).

A second SPE extraction was conducted on 7 of the 87 samples from USGS 11-10-ft. Following the initial saturated paste extract, the residual material was extracted a second time. The first extract (SPE) was labeled "A" (SPE-A) and the second extract was labeled "B" (SPE-B) (Appendix B11).

Selected samples from USGS 11-10-ft were subjected to sequential water extraction (SWE) of Se. Sequential water extractions were run on 44 fresh samples, designated A, some of which were splits derived from samples that were subjected to SPE. For the SWE samples, $10 \mathrm{ml}$ of deionized water was added to $5 \mathrm{~g}$ of sample. The mixture was allowed to set overnight, and then shaken for two hours at a speed of 10 on a wrist-action shaker. The mixture was centrifuged at $5000 \mathrm{rpm}$ for 25 minutes in an IES-Centram p4r centrifuge, and then filtered through a $0.45 \mu \mathrm{m}$ cellulose nitrate membrane filter. The filtrate was then analyzed. Subsequent sequential extractions were conducted by adding an additional $10 \mathrm{ml}$ of water to the solid residue, followed by repetition of all other steps, for up to six sequential extractions $\left(2^{\text {nd }}\right.$ through $7^{\text {th }}$ extracts $)$. For 15 of the 44 samples, a second split was leached, resulting in analyses of duplicate samples, labeled "B." Results for all SWE analyses for USGS 11-10-ft are presented in Appendix B13. 


\section{Results}

\section{Estimates of Analytical Precision}

The American Society for Testing and Materials (ASTM) standard method for the determination of Se in rock samples (ASTM 3052 D1) was used in this study. ASTM evaluated the 95 percent confidence interval (CI 95\%) for the method by conducting replicate analyses of National Institute of Standards and Testing (NIST) standard reference material (SRM) 2704, Buffalo River Sediment. NIST reports a Se concentration of $1.1 \mu \mathrm{g} / \mathrm{g}(\mathrm{ppm})$ in SRM 2704 but does not certify this value, possibly because only one analytical method was used to determine Se. ASTM analyzed SRM 2704 a number of times for 13 elements, including Se $(n=4)$, and reported a mean Se concentration of $1.13 \mu \mathrm{g} / \mathrm{g}(\mathrm{ppm})$ with a CI $95 \%$ of $0.9 \mu \mathrm{g} / \mathrm{g}$ (table 1). Thus, the determination of Se by the ASTM 3052 standard method may be relatively imprecise at the $1 \mu \mathrm{g} / \mathrm{g}$ (ppm) concentration level and below.

In the present study, the precision of the ASTM 3052 method for the determination of Se was estimated on the basis of analyses of replicate samples from USGS 9. Each of 12 one-foot increment samples from USGS 9 was analyzed twice, once as part of the lithology sampling, USGS 9-LITH (Appendix B1), and once as part of the 10-foot increment sampling, USGS 9-10-ft (Appendix B2). Inspection of the two sets of analyses indicate that the Se values from USGS 9LITH samples are, in general, lower than the Se values for the USGS 9-10-ft samples (table 2).

As a result of the apparent differences in the duplicate analyses for Se in the twelve coincident samples from USGS 9, the twelve coincident samples were used to estimate the precision of the analytical method. In order to develop a data set that could be evaluated statistically, each of the twelve USGS 9-10-ft samples that was a duplicate of a USGS 9-LITH sample was sub-sampled two additional times. These sub-samples were then digested, and each digestion was analyzed three times. Thus, each of the twelve USGS 9-10-ft samples was subsampled a total of three times, designated as A, B, and C. The sub-samples were digested and each of the digestion liquors was analyzed in triplicate (identified as 1,2, and 3). The data are shown in Appendix B14.

An estimate of the precision of the ASTM 3052 analytical method was based on statistical evaluation of the Se concentration data from three sub-samples and 3 replicate analyses of each sub-sample for 12 USGS 9-10-ft samples, which are coincident with 12 samples from USGS 9LITH. The mean, standard deviation, number of analyses $(\mathrm{N}=9)$, and the 95 percent confidence interval (CI 95\%) for the mean are shown in table 3 for the 12 coincident samples. A normalized metric was calculated in order to compare the 95 percent confidence intervals for mean Se concentrations among the 12 coincident samples in USGS 9, where replicate analyses may vary by two orders of magnitude (Appendix B14) and mean Se concentrations (table 3) are less than 1000 $\mu \mathrm{g} / \mathrm{kg}(1 \mathrm{ppm})$, with the 95 percent confidence interval reported by ASTM, where the mean Se concentration (table 1) is greater than $1 \mu \mathrm{g} / \mathrm{kg}(1 \mathrm{ppm})$. The normalized metric, used here to indicate precision of results, is the CI 95\% divided by the mean Se concentration, for each sample. The CI 95\% reported by ASTM was divided by the mean reported by ASTM yielding a value of 0.80 (table 1). In the present study, for each sample, the CI 95\% was divided by the mean and the 12 resultant values were averaged giving the lab's precision of the ASTM 3052 method as 0.80 (table 3). Thus, the precision of analyses by the ASTM 3052 method, estimated by the metric CI 
95\% / mean in the present study is similar to the precision reported by ASTM, even though the Se concentrations are lower in the present study (table 3) compared to the ASTM study (table 1).

\section{Core Comparisons: a Test for Spatial Variation in Selenium Concentrations in Middle Pennsylvanian Coal-Bearing Strata}

A principal objective of the present study was to evaluate spatial variation of Se concentrations in coal-bearing strata in the central Appalachian basin. Spatial variation in Se concentrations, as used in this report, refers to both stratigraphic variation (vertical trends) and regional variation (lateral trends).

\section{Stratigraphic Variation}

An analysis of stratigraphic variation of Se in Middle Pennsylvanian strata included the lower part of the Allegheny Formation down through the middle of the Kanawha Formation (Appendices A1, A2, A3). A stratigraphic comparison of Se concentration data was made within each of the three cores that were evaluated in the present study. The stratigraphic comparisons were based on the mean and $95 \%$ confidence interval of two specific stratigraphic intervals in each of the three cores. The two stratigraphic intervals were selected on the basis of a visual inspection of the data derived from analyses of samples from the first core that was analyzed, USGS 9-LITH (fig. 2). Visual inspection of the Se concentration values in USGS 9-LITH indicated that Se concentrations were commonly above the limits of detection from the Stockton A coal bed down to the Chilton A coal bed, whereas Se concentrations were commonly below the limits of detection from the Chilton A coal bed down to the Fire Clay coal bed. Thus, the two stratigraphic intervals consist of an upper interval from the base of the Stockton A coal bed down to the top of the Chilton A coal bed, and a lower interval from the base of the Chilton A coal bed down to the top of the Fire Clay coal bed. The plots of Se concentrations versus depth for the other core data sets are presented for USGS 9-10-ft (fig. 3), USGS 11-10-ft (fig. 4), and USGS 12-10-ft (fig. 5).

The univariate statistics for the two stratigraphic intervals for each core are presented in table 4. Comparisons of mean Se concentrations and their respective CI 95\% for each stratigraphic interval are shown in figure 6 for each core. The rank order of the means of Se concentrations is always greater in the upper stratigraphic interval relative to the lower stratigraphic interval (table 4). However, only in USGS 9 is the mean value for Se concentration in the upper stratigraphic interval (from the bottom of the Stockton A coal bed down to the top of the Chilton A coal bed) statistically greater than that for the lower stratigraphic interval (from the bottom of the Chilton A coal bed down to the top of the Fire Clay coal bed). Statistical analyses of both samplings of USGS 9 (-LITH and -10-ft) indicate that the mean Se values in strata overlying the Chilton A Coal bed (553 and $666 \mu \mathrm{g} / \mathrm{kg}$ Se, respectively) are greater than the mean Se values in strata that underlie the Chilton A coal bed (64 and $329 \mu \mathrm{g} / \mathrm{kg}$ Se, respectively) (table 4). In contrast, based on t-tests, there are no statistical differences between the means of Se concentrations in the two stratigraphic intervals in either USGS 11-10-ft or USGS 12-10-ft (table 4). The apparent stratigraphic trend in Se concentrations in coal-bearing strata, exclusive of coal, in USGS 9 is consistent with stratigraphic trends in Se in coal beds as reported by WVGES (2002) for West Virginia and Neuzil and others (2005) for the Appalachian Plateau region. Although the rank-order of Se values in the upper and lower stratigraphic interval is consistent among the three cores, stratigraphic trends in Se concentrations cannot be verified statistically in either USGS 11 or USGS 12 for the stratigraphic intervals considered. Thus, a stratigraphic trend in Se concentrations in rock in the Middle Pennsylvanian coal-bearing strata cannot be stated with certainty on the basis of the present study. 


\section{Regional Variation}

Regional variation was tested on the basis of three cores, USGS 9, USGS 11, and USGS 12 spaced approximately $50 \mathrm{~km}$ apart (fig.1). Regional variation among cores was evaluated by a statistical t-test comparison of mean Se concentrations $(\mu \mathrm{g} / \mathrm{kg})$ for each of the two stratigraphic intervals. The results are summarized in table 5. The rank order of the mean Se concentrations in the upper stratigraphic interval is USGS 9-10-ft > USGS 9-LITH > USGS 12-10-ft > USGS 11-10$\mathrm{ft}$. Statistical t-tests show that USGS 9-10-ft is greater than both USGS 12-10 ft and USGS 11-10 $\mathrm{ft}$ and that USGS 9-LITH is greater than USGS 11-10-ft. Otherwise, mean Se concentrations are statistically equal. For the lower stratigraphic interval, the rank order of the mean Se concentrations is USGS 9-10-ft > USGS 12-10-ft > USGS 11-10-ft > USGS 9-LITH. Statistical ttests show that mean Se concentration in USGS 9-10-ft samples is greater than mean Se concentration in USGS 9-LITH samples. All other mean Se concentrations are equal for the lower stratigraphic interval. There are no differences in mean Se concentration between any two cores that hold for both the upper and lower stratigraphic interval. On the basis of data derived from analyses of samples obtained from the three cores that were tested in this study, there are no apparent regional variations (trends) in Se concentrations.

\section{Frequency Distribution of Selenium Concentrations in Three Cores}

The univariate statistics and frequency distribution information for Se concentrations in all 1-foot increment samples collected at 10-foot intervals (USGS 9-10-ft, USGS 11-10-ft, and USGS 12-10-ft), are shown in table 6. The Se values for USGS 9-LITH were not used for this analysis because of the different sampling method. The two highest Se values, 6820 and $3300 \mu \mathrm{g} / \mathrm{kg}$, are considered high outlier values because they are each approximately twice the value of the next highest Se concentration (table 6). These samples were dropped in order to examine the frequency distribution of Se concentrations in the remaining 234 samples collected at 10-foot intervals (fig.

7). Concentrations below the limit of detection (ND) account for 33 percent of all Se concentration values. Sixty eight percent of the values are less than $500 \mu \mathrm{g} / \mathrm{kg}$, and eighty nine percent of the values are below $1000 \mu \mathrm{g} / \mathrm{kg}$. Therefore, the Se data appear to have a log normal distribution, which is typical for trace element geochemical data. Whether Se concentrations below the detection limit are assigned a value of zero or $5 \mu \mathrm{g} / \mathrm{kg}$ (half the limit of detection), the mean and standard deviation change by $2 \mu \mathrm{g} / \mathrm{kg}$, which is less than 1 percent of the value of the mean and standard deviation (table 6). In this study a value of zero was assigned to samples below the detection limit, which made little overall difference to the statistics.

\section{Selenium Concentrations and Dominant Lithologies (Rock Types)}

Four dominant rock types in USGS 9 were sampled for USGS 9-LITH in proportions similar to their total thickness in the entire USGS 9 core (Appendix A5). The proportions of the four dominant rock types in core USGS 9 and the two sample sets taken from the core are as follows: claystone and mudstone, shale, siltstone, and sandstone each represent $6,14,14$, and 65 percent of core USGS 9; 9, 20, 23, and 48 percent of samples in USGS 9-LITH; and 14, 5, 10, and 71 percent of samples in USGS 9-10-ft. The mean Se concentrations and 95 percent confidence intervals $(\mu \mathrm{g} / \mathrm{kg})$ within each of the four lithologies were used to evaluate the relation, if any, between rock-type and Se concentrations. Univariate statistics and comparisons among dominant lithologies were conducted on the two data sets from USGS 9, USGS 9-LITH samples selected by lithology and USGS 9-10-ft samples collected every ten feet, and are summarized in table 7. 
The mean Se concentration \pm the 95 percent confidence interval for the four dominant lithologies from USGS 9-LITH and USGS 9-10-ft are shown in figure 8 and figure 9. Among the four dominant rock types in the two samplings of USGS 9, the rank order of the mean Se concentrations are higher in siltstone than in claystone, shale, or sandstone. However, t-test statistical analyses show that only mean Se concentrations in siltstone are higher than in claystone for both samplings (table 7).

\section{Selenium Concentrations in Roof, Parting, and Floor samples}

T-test analyses of the Se concentration data derived from roof (rock immediately above coal beds), parting (rock within coal beds), and floor (rock immediately below coal beds) samples from USGS 9 indicate that the mean Se concentrations in coal-bed roof, parting, and floor samples are statistically equal (table 8). Because the mean Se concentrations in roof, parting, and floor samples are equal, the three data sets can be combined and referred to as RPF. The univariate statistics for USGS 9-RPF samples are shown in table 9. The mean Se concentration for all USGS 9-RPF samples was compared to the mean Se concentrations of the four dominant lithologies data sets derived from each of two samplings of USGS 9 (figs. 10 and 11). The statistical t-test comparisons of RPF samples with samples of four dominant lithologies in USGS 9-LITH and USGS 9-10-ft are summarized in table 10 .

Results show that RPF samples are likely to have Se concentrations that are similar to siltstones, but greater than claystones, shales, and sandstones. The statistical similarity between RPF samples and shale samples from USGS 9-10-ft is due to the large dispersion of the mean, indicated by the large 95 percent confidence interval, for the few $(\mathrm{N}=4)$ shale samples (table 7).

The statistical t-test evaluation comparing mean Se concentrations separately in each of the roof, parting and floor sample data sets with each of the four dominant rock types (lithologies) from USGS 9-LITH samples (fig. 8) and USGS 9-10-ft (fig. 9) are summarized in table 10. The results are similar to those comparing RPF samples to the four dominant lithologies. Roof and floor samples have Se concentrations similar to siltstone samples whereas roof, parting, and floor samples have Se concentrations greater than claystone, shale, and sandstone samples for USGS 9LITH (fig. 8; table 10). The rank-order of the means for roof, parting, and floor samples and the four dominant lithology types of samples from USGS 9-LITH is as follows: parting $>$ floor $>$ roof $>$ siltstone $>$ sandstone $>$ shale $>$ claystone (tables 7 and 8). For USGS 9-10-ft, differences in the mean Se concentration are not discernible between roof samples and the four dominant lithologies, whereas parting and floor samples tend to have Se concentrations greater than claystone and sandstone samples and similar to shale and siltstone samples (fig. 9; table 10). The rank order of the means for roof, parting, and floor samples and the four dominant lithologies in USGS 9-10-ft is as follows: parting $>$ siltstone $>$ floor $>$ roof $>$ sandstone $>$ claystone $>$ shale (tables 7 and 8 ).

\section{Relation Between Selenium, Mineralogy, and Major Element Oxides Concentrations}

Pearson's product moment correlation coefficients were calculated between Se and each mineral and major element oxide concentration in each core sampling. Few significant correlations (at the 5 percent level of significance) were found. There are no significant correlations of Se with pyrite or $\mathrm{Fe}_{2} \mathrm{O}_{3}$ in any of the four core samplings. More than half of the samples in each of the four core sample sets have zero values (below detection limit) for calcite, pyrite, and sulfur (Appendices B5, B6, B7, B8). 
Selenium concentration is significantly correlated with siderite in samples from USGS 9LITH (fig. 12). Selenium concentrations for samples from USGS 9-10-ft are not significantly correlated with any mineral or major element.

Se concentrations in samples from USGS 11-10-ft include one point with high Se, calcite, and $\mathrm{CaO}$ concentrations (Appendices B3 and B7; fig.13). When this high value sample is included in the data set, the correlations between Se and calcite and between $\mathrm{Se}$ and $\mathrm{CaO}$ appear to be significant (fig. 13). Upon removal of the data point with high $\mathrm{Se}$, calcite, and $\mathrm{CaO}$, and given that most of the samples have calcite concentrations that are below the limit of detection, there is no significant correlation between Se and calcite or CaO in USGS 11-10-ft (fig. 13).

For samples from USGS 12-10-ft, Se is significantly correlated with clay minerals (chlorite, kaolinite, and illite), calcite, and $\mathrm{K}_{2} \mathrm{O}$ (fig. 14). The correlation between Se and chlorite is weak as there are many points without detectable Se or measurable amounts of chlorite, and the remainder of the points are distributed above and below the trend line. The correlations between Se and kaolinite, illite, calcite, and $\mathrm{K}_{2} \mathrm{O}$ are also weak and thus the concentration of these minerals or $\mathrm{K}_{2} \mathrm{O}$ is not a good predictor of the Se concentration.

\section{Sulfur, Loss on Ignition, and Selenium in Roof, Parting, and Floor Samples}

The data for coal-bed roof, parting, and floor samples from USGS 9 (Appendix B9) were analyzed to determine if there is a significant correlation between Se and total sulfur. The Se concentration has a range from below detection to $3340 \mu \mathrm{g} / \mathrm{kg}$ and total sulfur has a range of 0.01 2.22 percent for 26 samples. The results indicate that Se concentrations in the selected roof, parting and floor samples do not statistically correlate with total sulfur concentrations (a proxy for the mineral pyrite, $\mathrm{FeS}_{2}$ ) (fig. 15). Therefore, it is unlikely that a significant portion of Se is associated with pyrite in these samples.

The data for coal-bed roof, parting, and floor samples from USGS 9 were also analyzed to determine if there is a significant correlation between Se and organic matter. The loss on ignition data, calculated from ash analyses, were used as a proxy for the amount of organic matter. The range of loss on ignition is $6-48$ percent (Appendix B9). Statistical evaluation of the data indicate that the Se concentrations in the roof, parting, and floor samples are correlated with the loss on ignition at the 5 percent level of significance $\left(R=0.480\right.$, which exceeds the critical value for $R_{(0.05)}=$ 0.388) (fig. 16). The positive correlation between Se and loss on ignition suggests that Se may occur as organically bound Se.

The statistical comparisons conducted in the present study do not provide an unequivocal indication of any relation between Se concentrations and sample mineralogy or sample chemistry. The positive correlations that were noted between Se concentrations and sample mineralogy cannot be applied with certainty on the basis of the data derived in the present study. Therefore, further investigation is needed to determine the mode of occurrence of Se in coal-bearing strata and its association with both inorganic and organic material.

\section{Aqueous Extraction of Soluble Selenium}

There is no generally accepted standard method for the determination of soluble Se in rock samples. Therefore, in order to estimate soluble Se in the present study, both the saturated paste 
extract (SPE) and sequential water extraction (SWE) methods described above were used to evaluate the amount of Se extracted by water.

The concentration of Se extracted into water from rock, was compared to the total amount of Se in the rock. The Se concentration ( $\mu \mathrm{g} / \mathrm{L}$ or $\mathrm{ppb})$ extracted from rock samples by the SPE method was compared to the total Se concentration ( $\mu \mathrm{g} / \mathrm{kg}$ or $\mathrm{ppb})$ in rock samples from USGS 910-ft (fig. 17), USGS 11-10-ft (fig. 18), and USGS 12-10-ft (fig. 19). The Se concentration ( $\mu \mathrm{g} / \mathrm{L})$ extracted from rock samples by the SWE method also was compared to the total Se concentration $(\mu \mathrm{g} / \mathrm{kg})$ in rock samples from USGS 11-10-ft (fig. 20). In several rock samples, the Se concentration is below the detection limit of the GFAA method, yet detectable concentrations of Se are leached by SPE or SWE methods. In other cases, high concentrations of Se are measured in rock samples yet low concentrations of Se are leached from the rock (figs. 17, 18, 19, 20). Se concentrations in SPE leachates from rock do not correlate with Se concentration in the rock in any of the three cores (figs. 17, 18, and 19). Furthermore, the Se concentration in leachates from either the SPE or the SWE leaching method do not correlate with the Se concentration in the rock in core USGS 11 (figs. 18 and 20).

The reproducibility of water extraction of soluble Se from freshly ground rock samples was examined in core USGS 11. Comparison of Se concentration in leachates of duplicate subsamples, SWE-A and SWE-B, give consistent results (fig. 21). It is not clear why Se concentrations are higher in SWE-B than in SWE-A in 13 of 15 samples leached in duplicate (Appendix B13). In the SWE extractions, two times as much mass of water $(10 \mathrm{ml})$ as rock $(5 \mathrm{~g})$ was used and each sub-sample was processed in the same way. The correlation coefficient is high with an $\mathrm{R}=0.9709$ for 15 samples (fig. 21). Although SWE leaching is not a standard method to determine soluble Se, it appears to give reliable results, and the scatter of data points suggests that soluble Se concentrations appear to be reproducible within a factor of two.

The two methods of extracting soluble Se from rock were compared to determine whether the water to rock mass ratio used in the extraction influences either the concentration of Se in the water-extract leachate or the amount of Se extracted from the rock. The SPE method used $0.011 \mathrm{~L}$ water / $0.030 \mathrm{~kg}$ rock whereas the SWE method used $0.010 \mathrm{~L}$ water $/ 0.005 \mathrm{~kg}$ rock. Thus the SWE leach method used 5.4 times more water per kg of rock than the SPE method. The SPE-A and the SWE-A extractions, both first extraction leachates, were conducted on 44 duplicate rock samples from USGS 11-10-ft. Two observations were made. First, the concentration of Se is higher in SPE-A leachates than in SWE-A leachates in 38 of 44 samples (fig. 22) with a high correlation coefficient $\mathrm{R}=0.8340$ that suggests each method gives internally consistent results. The lower $\mathrm{Se}$ concentrations in SWE-A leachates compared to SPE-A leachates may be a result of dilution by more water used per mass of rock leached in the SWE method compared to the SPE method.

Second, in order to compare the amount of Se leached from rock by the two methods, the Se concentrations in SPE-A and SWE-A were normalized to account for the mass of water and rock used and is hereafter referred to as "absolute Se" with units of $\mu \mathrm{g}$ Se in solution / kg of rock leached. For SPE, the absolute Se is calculated by multiplying the Se concentration in leachate $(\mu \mathrm{g}$ $\mathrm{Se} / \mathrm{kg}$ leachate) by $0.011 \mathrm{~kg}$ leachate $/ 0.030 \mathrm{~kg}$ rock and for SWE the absolute Se is calculated by multiplying the Se concentration in leachate ( $\mu \mathrm{g} \mathrm{Se} / \mathrm{kg}$ leachate) by $0.010 \mathrm{~kg}$ leachate $/ 0.005 \mathrm{~kg}$ rock. Comparison of the absolute Se determined for the SWE and SPE methods for USGS 11 shows that the absolute Se extracted by SWE method is greater than the absolute Se extracted by the SPE method in 33 of 44 samples (fig. 23). The slope of the line in figure 23 indicates that the 
SWE method extracts twice as much Se from rock as the SPE method. This suggests that the more water that comes in contact with rock, the more Se may be leached from the rock.

Sequential water extractions of Se by the SWE method were conducted in this study to determine whether the concentration of Se in leachates changes over time as successive amounts of water come into contact with the rock (Appendix B13; fig. 24). The results show that in cases where the initial leachate Se concentrations are high, approximately $30 \mu \mathrm{g} / \mathrm{L}$ or higher, there is a generally rapid decrease in Se concentrations in successive leachates. After several leaches, approximately four, the concentration of Se is lower, generally less than $15 \mu \mathrm{g} / \mathrm{L}$, and fairly constant (fig. 24).

\section{Discussion}

\section{Selenium Concentration, Lithology, and Mineralogy}

The average Se concentrations in dominant rock types (lithologies) in this study were compared with the average Se concentrations in upper continental crust (Wedepohl, 1995; Rudnick and Gao, 2003) and sedimentary rocks (Horn and Adams, 1966; Baedecker and others, 1998). The average Se concentration in upper continental crust is estimated as $0.083 \mathrm{ppm}$ by Wedepohl (1995) and 0.09 ppm by Rudnick and Gao (2003). However, sedimentary rocks only represent a small portion, approximately 14 percent, of the upper continental crust (Wedepohl, 1995). Horn and Adams (1966) estimated Se concentrations in six sedimentary and marine domains, including shale and sandstone, based on iterative geochemical mass balance calculations, starting with a range of Se concentrations reported in the literature. Se could not be brought into an internally consistent mass balance in the model, probably as a result of significant volcanic input, and should be considered as an order of magnitude estimate (Horn and Adams, 1966). The range and calculated average Se concentrations for shale and sandstone reported by Horn and Adams (1966) are similar to those for the central Appalachian basin shale and sandstone samples analyzed in this study (table 11). Se concentrations in shale, siltstone, and sandstone samples from the western U.S. are reported in the PLUTO data base (Baedecker and others, 1998). Average Se concentrations calculated for these western U.S. samples are approximately 5 to 7 times the average $\mathrm{Se}$ concentrations in shale, siltstone, and sandstone in the central Appalachian basin samples in this study (table 11). These comparisons suggest that the Se concentrations in central Appalachian sedimentary rocks associated with coal beds are not anomalously high when compared to upper continental crust, global estimated average sedimentary rocks, or western U.S sedimentary rocks.

Several recent studies have examined Se concentrations in various lithologies collected from cores drilled in coal-bearing strata in southern West Virginia (Jenkins and Schaer, 2005; Mullennex, 2005; Roy, 2005; Vesper and Roy, 2006). Samples in those studies were collected from different stratigraphic intervals, selected using different criteria, and categorized into different lithologic groups compared to this report. Also, data were presented with different emphases than in this report, for example, contrasting samples that were located close to or far from coal beds using either $5 \mathrm{ft}$ (Mullennex, 2005) or $2 \mathrm{ft}$ (Vesper and Roy, 2006) as the operational cutoff distance. Nevertheless, some general comparisons can be made to data presented in this report. Mullennex (2005) sampled 5 cores in one mine in southwestern West Virginia in the stratigraphic interval from the No. 6 Block coal, lower Allegheny Formation, down to the Coalburg coal, upper Kamawha Formation. This interval partially overlaps the upper part of the "upper stratigraphic interval" in this report. Mullennex (2005) presents mean Se concentrations for all shale and all 
sandstone, regardless of proximity to coal beds. The mean Se concentrations for all shale and all sandstone in USGS 9-10-ft, USGS 11-10-ft, and USGS 12-10-ft core samples (table 11) are within a factor of three of those found by Mullennex (2005). Given the differences in sampling protocol and stratigraphic interval of Mullennex (2005) and this report, these results are fairly similar.

The present study evaluated Se concentrations in four rock types (claystone, shale, siltstone, and sandstone) in one core, USGS 9, to determine relations, if any, among rock-type and Se concentrations. For both USGS 9-LITH and USGS 9-10-ft samples, mean Se concentrations were equal in shale and claystone whereas mean Se concentrations in siltstone were greater than claystone (table 7). Other comparisons of mean Se concentrations among the lithologies were inconsistent from USGS 9-LITH samples to USGS 9-10-ft samples (table 7).

Mineralogy was determined by X-ray diffraction on all samples in four core sample sets. In one core, a correlation was found between siderite and Se whereas in another core, clay minerals (chlorite, kaolinite, and illite) correlated with Se. Calcite is below detection in most of the samples. In the few samples where calcite is present at high concentrations, the data suggest it may be associated with high Se content. There is no correlation between Se and any mineral that holds for all cores. Thus, if statistically significant correlations between Se concentrations and mineralogy exist, they are below the level of detection by the combined sampling, analytical, and statistical methods used in the present study.

\section{Comparison of Se Concentration in Roof, Parting, Floor, and Four Dominant Lithologies}

Coal-bed roof, parting, and floor samples from core USGS 9 were evaluated to determine the relation, if any, between these organic-rich samples that are adjacent to coal beds and their Se concentrations. The equality of the mean values and variances for each type of sample were used in the comparison. The variances and means are statistically equal among Se concentration for roof, parting, and floor samples as shown in table 8.

Collectively RPF (roof, parting, and floor) samples have mean Se concentrations equal to siltstone and greater than claystone and sandstone in core USGS 9 (figs. 10, 11; table 10). Another way of stating this is that organic-rich RPF samples located adjacent to coal beds have higher Se concentrations than sandstone samples with a distance from coal beds unspecified, for one core analysed. Jenkins and Schaer (2005) sampled 7 cores from 3 areas in southern West Virginia in the stratigraphic interval from the No. 5 Block coal, lower Allegheny Formation, to the Winifrede coal, upper Kanawha Formation. They found higher concentrations of Se in dark organic-rich rock close to coal beds compared to sandstone farther from coal beds. Roy (2005) and Vesper and Roy (2006) examined one core in the Coalburg through the Winifrede interval in the upper Kanawha Formation. Vesper and Roy (2006) and Mullennex (2005) found a trend of more Se in organic-rich rock ('carbolith' or 'coal and shale') than shale than sandstone. The rank order for mean Se concentration for USGS 9-LITH was RPF (organic-rich rock close to coal) $>$ sandstone $>$ shale and for USGS 9-10-ft RPF > sandstone = shale (tables 7, 10). The difference in the rank order of the mean Se concentration of various lithologies (organic-rich rock, shale, and sandstone) compared between results found in this report and those published in the literature may be a result of different sampling protocols and different stratigraphic intervals examined.

In this report, the Se concentrations in RPF samples do not correlate with sulfur (a proxy for pyrite) but do correlate with loss on ignition (a proxy for organic matter). Similarly, Mullennex 
(2005) found no correlation between Se and total, pyritic, or organic sulfur in samples from the No. 6 Block coal bed through the Coalburg coal bed stratigraphic interval. Roy (2005) and Vesper and Roy (2006) did not find any strong correlation between Se and sulfur content or organic matter in rock samples.

\section{Mobilization of Soluble Selenium}

The results of the saturated paste extract (SPE) and sequential water extraction (SWE) studies reported herein should be used with caution because standard leaching methods have not been developed, nor have definitive Se laboratory leaching studies been conducted. The SPE results of this study suggest that total Se in rock is not a predictor for soluble Se. Roy (2005) and Vesper and Roy (2006) also noted that soluble Se was not correlated to total Se in rock. SPE or some other leaching procedure, rather than total Se values determined on whole-rock samples, may provide a more accurate indication of the potential for Se mobilization to streams following land disturbance.

The sequential water extraction (SWE) leaching method used in this study gives results that appear to be reproducible within a factor of approximately two (Appendix B13; fig. 21). Given the potential for differences in particle sizes, mineralogy, and modes of occurrence of Se in the duplicate sub-samples, this reproducibility is fairly good.

Comparison of the two leaching methods (SPE and SWE) used in this study suggest that the more water that comes into contact with rock, such as groundwater flow through rock, (1) the lower the concentration of resultant dissolved Se and (2) the more Se will be leached from the rock. In disturbed strata, the surface area of rock exposed per mass of rock is almost certainly less than in the $<60$ mesh rock samples used for SPE and SWE leaching in this study. Therefore, one would expect less efficient leaching of Se in disturbed rock strata than in these laboratory studies.

The sequential leaching studies presented here suggest that Se concentrations of water passing through disturbed rock strata may have an initial increase in Se followed by a decrease in Se concentrations. Thus, soluble Se may be removed rapidly from disturbed rock strata with freshly exposed surfaces. Bonta and Dick (2003) observed an increase in Se concentration in streams below coal mining, at three of three mines studied during mining in the northern Appalachian basin in Ohio. They found that at one of two coal mines with data after mining, Se concentrations decreased to pre-mining levels within 6 years. The sequential leaching studies presented here indicate that the "half life" of dissolution of Se from coal-bearing lithologies may be relatively short; suggesting that the relative enrichment of Se in streams draining disturbed areas may decrease to baseline levels within a relatively few years.

\section{Summary and Conclusions}

The results and conclusions of the present study are summarized as follows:

- The precision of the analytical results for total Se in rock samples presented herein are consistent with the precision of the analytical method, ASTM 3052, that was used.

- The average Se concentrations in the four dominant lithologies in coal-bearing strata in the central Appalachian basin, as determined in the present study, are similar to the global average 
Se concentrations reported for equivalent lithologies (Horn and Adams, 1966) and therefore are not anomalous.

- Rank order of the mean Se concentrations in all coal-bearing lithologies shows that mean Se concentrations are higher in upper strata (Stockton A coal bed to Chilton A coal bed) than in lower strata (Chilton A coal bed to Fire Clay coal bed) in three widely spaced cores in the central Appalachian basin in southern West Virginia. This stratigraphic trend is similar to the stratigraphic trend in Se concentrations in coal beds in the central Appalachian basin reported by Neuzil and others (2005).

- On the basis of data derived from analyses of samples obtained from three cores in this study, there is no demonstrable regional variation (trend) in Se concentrations.

- The present study evaluated Se concentrations in a variety of lithologies, rock types, to determine relations, if any, among rock-type and Se concentrations. The results indicate that average Se concentrations tend to be higher in siltstone compared to claystone, shale, and sandstone. When the means and variances of Se concentration are compared in claystone, shale, and sandstone, there are no statistically demonstrable differences. If differences exist, they are below the limits of verification by the methods used in the present study.

- Although Se concentrations correlate with some minerals (siderite, chlorite, kaolinite, and illite as determined by XRD) in some cores, Se does not consistently correlate with any mineral in all cores.

- Se concentrations were determined in selected coal-bed roof, parting, and floor samples from one core. When the data are evaluated statistically, taking into account the mean and variances, there are no demonstrable differences in mean Se concentrations among roof, parting, and floor samples.

- Se concentrations do not statistically correlate with total sulfur concentrations suggesting that there is not a correlation with pyrite in the selected coal-bed roof, parting, and floor samples. However, Se concentrations in the selected coal-bed roof, parting, and floor samples do correlate with the loss on ignition, which suggests an association of Se with organic matter. If so, rates of mobilization of Se from these organic-rich materials are expected to be controlled by relatively slow rates of chemical oxidation of the host organic matter. General principles of chemistry suggest that oxidation and dissolution of refractory organic compounds are typically quite slow at ambient conditions.

- The uncertainties associated with the analyses of low concentrations of Se in whole-rock samples and the lack of correlation between total Se in rock and susceptibility of Se to dissolution suggest that leaching tests, rather than whole-rock analyses, may provide a more useful estimation of the potential for Se dissolution and mobilization from coal-bearing strata and the potential for increased Se concentrations in surface streams as a result of land disturbances.

- The readily soluble fraction of total Se in coal-bearing strata is not known. However, the cursory study of sequential leaching conducted in the present investigation indicates that readily soluble Se may be rapidly removed from rock debris following disturbance of strata. It appears that the "half life" of dissolution is relatively short, suggesting that any relative enrichment of Se in streams draining disturbed areas may decrease to baseline levels within a relatively few years after disturbance. Substantiation of the conclusion that Se leaching from disturbed strata will have a short half life will require further testing at reclaimed sites. 
On the basis of the present study, the average concentrations of Se in Middle Pennsylvanian coal-bearing strata in the central Appalachian basin are not anomalous when compared to published values of similar rock types. In addition, the average and spread (mean and dispersion) of Se concentrations indicate that if either stratigraphic or regional trends exist, such trends can not be verified statistically by the methods used herein. Also, there is no apparent association of Se with a specific rock type (claystone, shale, siltstone, or sandstone) with the possible exception of Se enrichment in certain siltstones. Leaching test methods, rather than total Se content of rocks, may more accurately represent the potential for Se mobilization by land disturbance.

\section{References Cited:}

American Society for Testing and Materials (ASTM), Method 3052, Microwave assisted acid digestion of siliceous and organically based matrices, available on the web at:

http://www.epa.gov/sw-846/pdfs/3052.pdf.

Baedecker, P.A., Grossman, J.N., and Buttleman, K., 1998, National geochemical data base, PLUTO geochemical data base for the United States: U.S. Geological Survey, Digital Data Series, DDS 47 (CD-Rom).

Bonta, J.V., and Dick, W.A., 2003, Impact of coal surface mining and reclamation on surface water chemical concentrations and load rates in three Ohio watersheds: Journal of the American Water Resources Association, v. 39, no. 4, p. 793-816.

Bryant, G., McPhilliamy, S., and Childers, H., 2002, A survey of the water quality of streams in the primary region of mountaintop / valley fill coal mining, October 1999 to January 2001, in U.S. Environmental Protection Agency, Mid Atlantic Region, Mountaintop Mining Environmental Impact Statement, Appendix D, Stream chemistry final report, 102 p, available on the web at: http://www.epa.gov/region3/mtntop/appendix.htm\#appd.

Coleman, L., Bragg, L.J., and Finkelman, R.B., 1993, Distribution and mode of occurrence of selenium in US coals: Environmental Geochemistry and Health, v. 15, p. 215-226.

Dulong, F.T., Fedorko, N., Renton, J.J., and Cecil, C.B., 2002, Chemical and mineralogical analyses of coal-bearing strata in the Appalachian basin. U.S. Geological Survey Open-File Report 02-489, available on the web at: http://pubs.usgs.gov/of/2002/of02-489/.

Eble, C.F., and Hower, J.C., 1997, Coal quality trends and distribution of potentially hazardous trace elements in Eastern Kentucky coal: Fuel, v. 76, n. 8, p. 711-715.

Gluskoter, H.J., Ruch, R.R., Miller, W.G., Cahill, R.A., Dreher, G.B., and Kuhn, J.K., 1977, Trace elements in coal; occurrence and distribution: Illinois State Geological Survey Circular, no. 499, $154 \mathrm{pp}$.

Horn, M.K., and Adams, J.A.S., 1966, Computer-derived geochemical balances and element abundances: Geochimica et Cosmochimica Acta, v. 30, p. 279-297. 
Jenkins, G., and Schaer, N., 2005, The occurrence of selenium in the Upper Kanawha formation of the Pennsylvanian system in the southern West Virginia coalfields: West Virginia Department of Environmental Protection, available on the web at:

http://wvmdtaskforce.com/proceedings/05/Jenkins.pdf

Mullenex, R., 2005, Stratigraphic distribution of selenium in upper Kanawha-lower Allagheny formation strata at a location in southwestern West Virginia, presented at the 22nd Annual International Pittsburgh Coal Conference, Sept 12-15, 2005, Pittsburgh, Pennsylvania, USA, available on the web at:

http://www.mmal.com/company/pdf/papers/Winter\%2005_White\%20Paper\%20SC.pdf\#search= $\% 22$ mullennex\%20coal\%22

National Institute of Standards and Technology (NIST), Standard Reference Material 2704, Buffalo River Sediment, National Bureau of Standards Certificate of Analysis, available on the web at: http://ts.nist.gov/ts/htdocs/230/232/ARCHIVED_CERTIFICATES/2704.pdf.

Neuzil, S.G., Dulong, F.T., and Cecil, C.B., 2005, Spatial trends in ash yield, sulfur, selenium and other selected trace element concentrations in coal beds in the Appalachian Plateau region, U.S.A., U.S. Geological Survey Open-File Report 05-1330, available on the web at: http://pubs.usgs.gov/of/2005/1330/.

Rhoades, J. D., 1982, Soluble salts: in: A. L. Page, R. H. Miller, and D. R. Keeney (editors), Methods of soil analysis: Part 2: Chemical and microbiological properties. Monograph Number 9 (Second Edition). ASA, Madison, Wis., p. 167-179.

Roy, M., 2005, A detailed sequential extraction study of selenium in coal and coal-associated strata from a coal mine in West Virginia: Masters Thesis, West Virginia University, 93 pp.

Rudnick, R.L., and Gao, S., 2003, The composition of the continental crust: in R.L. Rudnick (editor), The Crust: Treatise on Geochemistry (Holland H.D., and Turekian, K.K., eds.), Elsevier, Amsterdam, v. 3, p. 1-64, available on the web at:

http://www.geol.umd.edu/ rudnick/Webpage/Rudnick_Gao_Treatise.pdf\#search=\%22rudnick\%2 Oand $\% 20$ gao $\% 22$

Vesper, D.J., and Roy, M., 2006, Selenium location and mode of occurrence in the Kanawha Formation rocks in West Virginia: West Virginia Mine Drainage Task Force Symposium, April 18-19, 2006, Morgantown, West Virginia.

Wedepohl, K.H., 1995, The composition of the continental crust: Geochimica et Cosmochimica Acta, v. 59, n. 7, p. 1217-1232.

West Virginia Geologic and Economic Survey (WVGES), 2002, Trace elements in West Virginia coals - Selenium: available on the web at:

http://www.wvgs.wvnet.edu/www/datastat/te/SeHome.htm

Yudovich, Y.E., and Ketris, M.P., 2006, Selenium in coal: a review: International Journal of Coal Geology, v. 67, p. 112-126. 


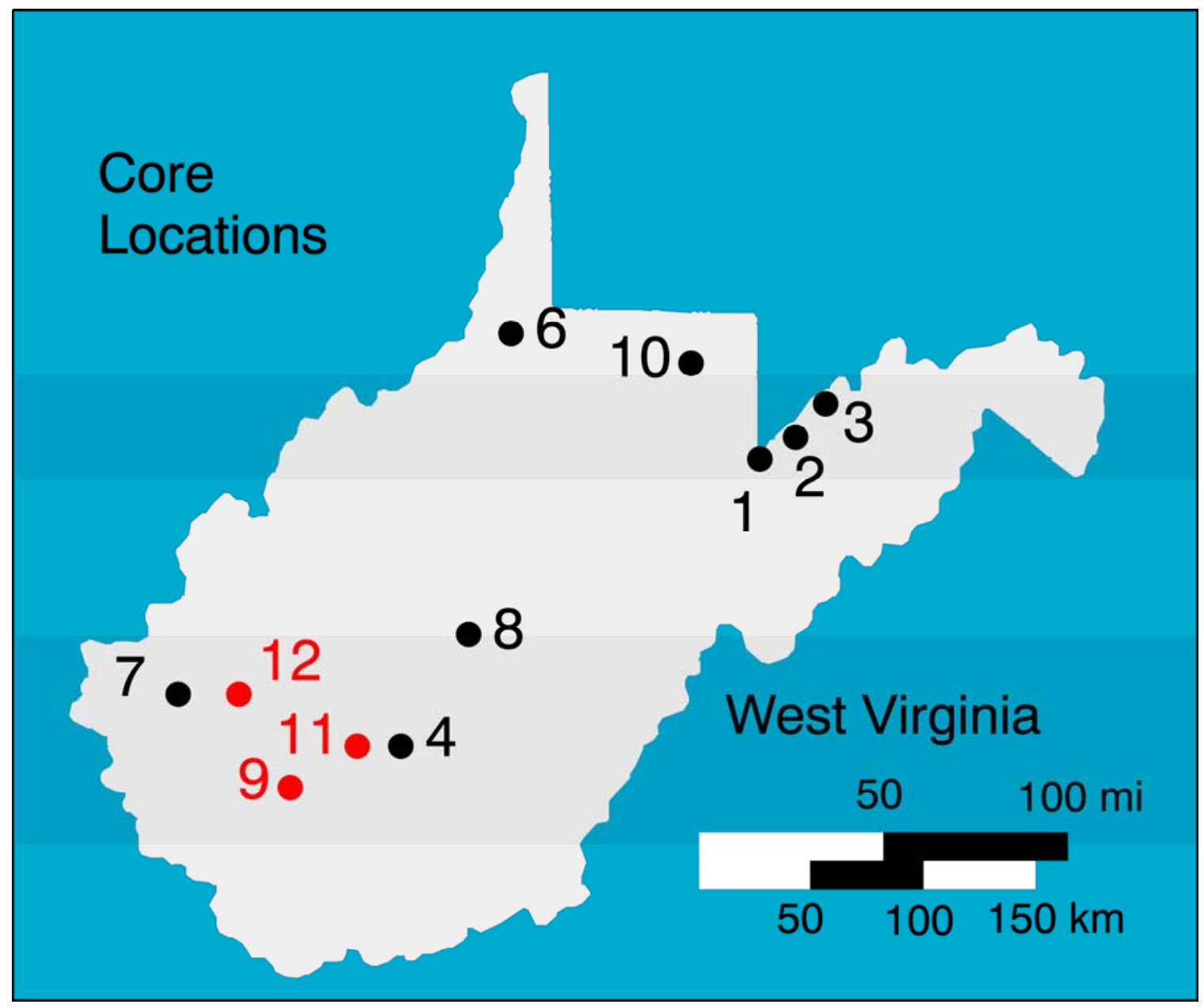

Figure 1. Map showing the location of three widely spaced cores (USGS 9, USGS 11, and USGS 12, indicated by red dots) in West Virginia, used in this study as part of a regional study of geochemical variation in the central Appalachian basin. 


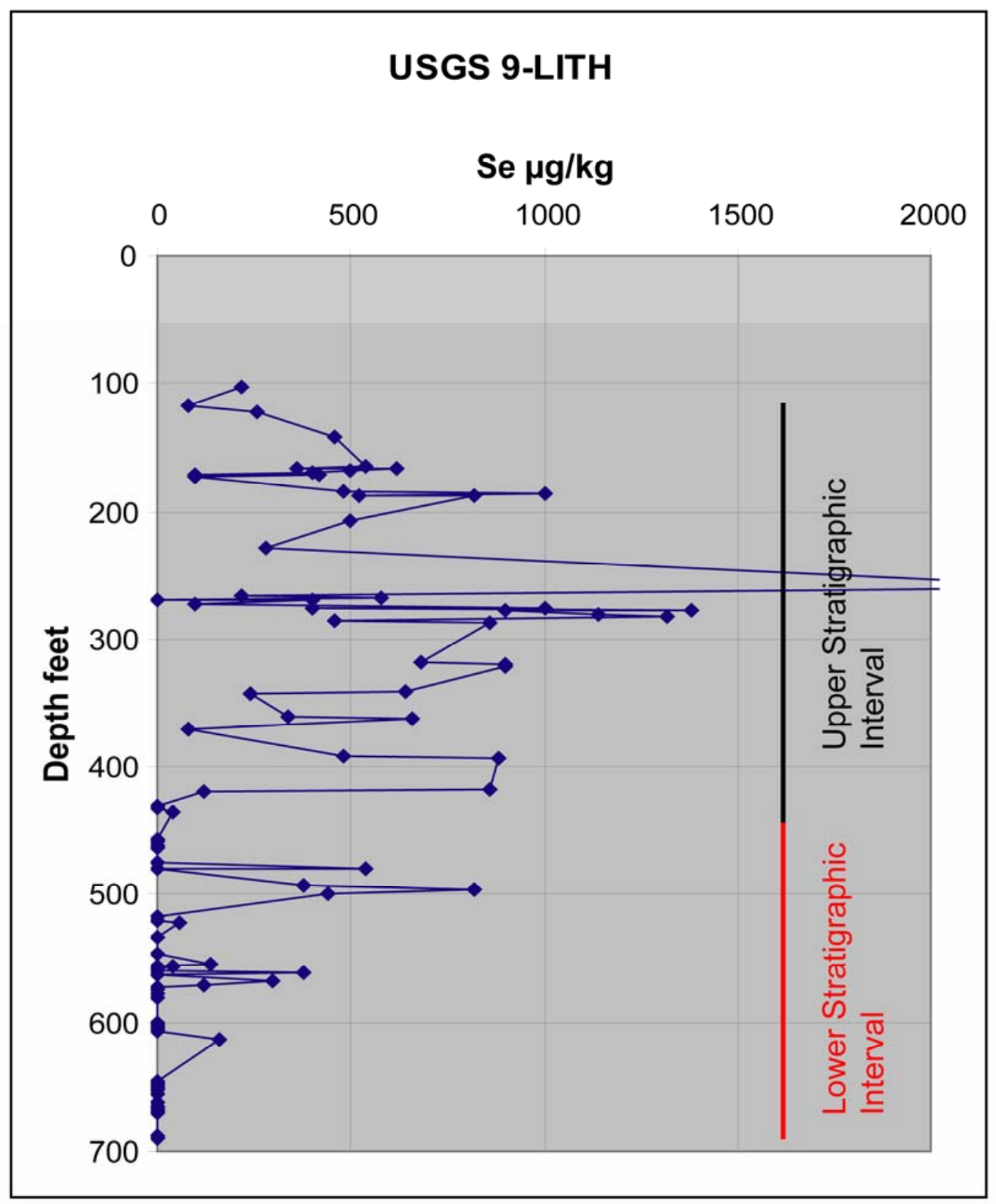

Figure 2. Se concentration $(\mu \mathrm{g} / \mathrm{kg})$ versus depth (ft) in core USGS 9-LITH samples, 1-foot increment samples selected by lithology.

The interval from the base of the Stockton A coal bed (114 feet) down to the top of the Chilton A coal bed (446 feet) is referred to as the upper stratigraphic interval. The interval from the base of the Chilton A coal bed ( 448 feet) down to the top of the Fire Clay coal bed (690 feet) is referred to as the lower stratigraphic interval. One Se value of 2440 $\mu \mathrm{g} / \mathrm{kg}$ at $258-259$ feet is larger than the maximum $\mathrm{x}$-scale of $2000 \mu \mathrm{g} / \mathrm{kg} \mathrm{Se}$.

Data are from Appendix B1. [symbols indicate depth in core and Se concentration of rock samples analyzed; lines connecting symbols are for illustration purposes only and do not indicate Se concentrations of rock] 


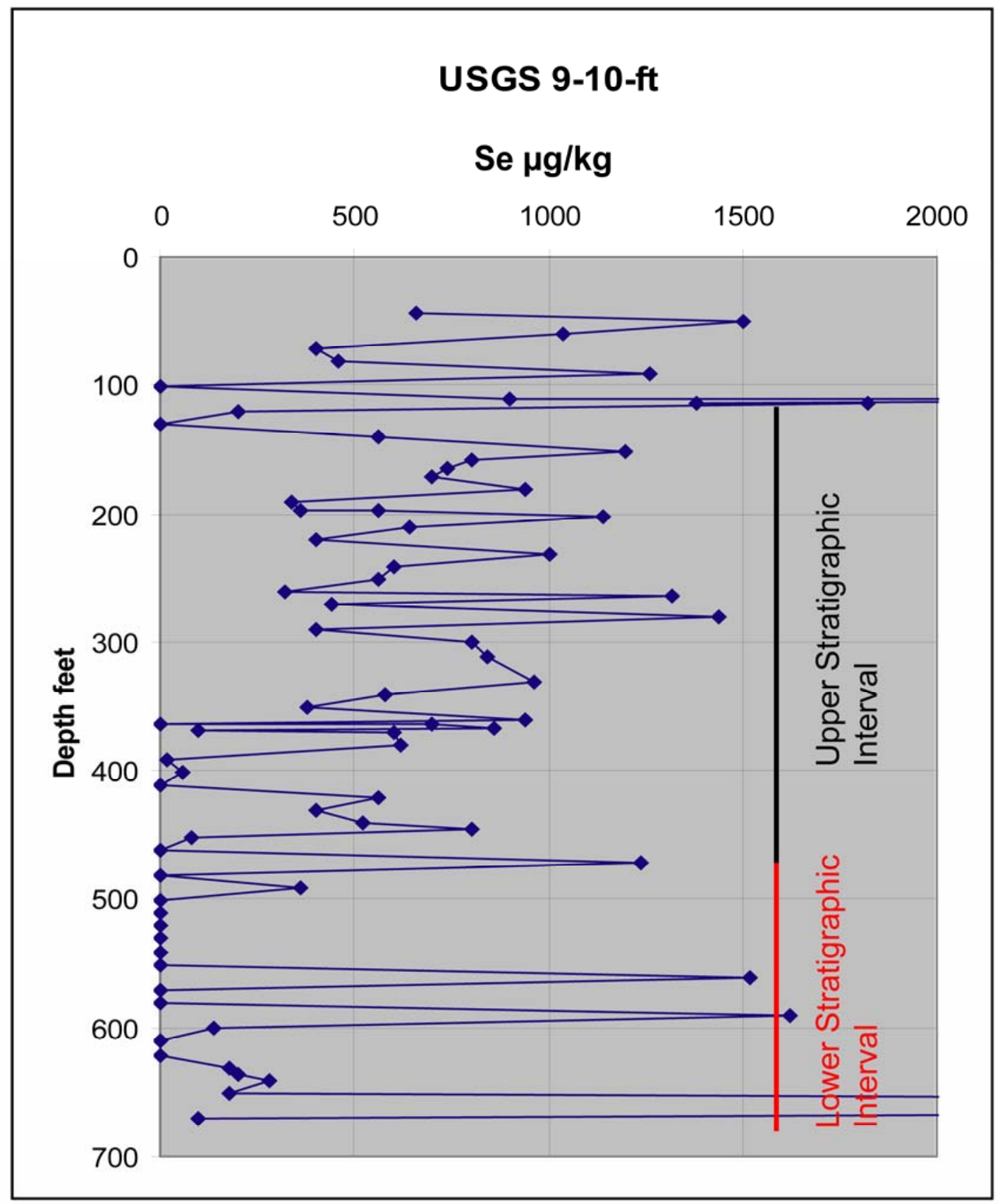

Figure 3. Se concentration $(\mu \mathrm{g} / \mathrm{kg}$ ) versus depth (ft) in core USGS 9-10-ft samples, 1-foot increment samples collected at 10 -foot intervals.

The interval from the base of the Stockton A coal bed (114 feet) down to the top of the Chilton A coal bed (446 feet) is referred to as the upper stratigraphic interval. The interval from the base of the Chilton A coal bed (448 feet) down to the top of the Fire Clay coal bed (690 feet) is referred to as the lower stratigraphic interval. Two Se values of 3300 $\mu \mathrm{g} / \mathrm{kg}$ at $110.42-110.90 \mathrm{feet}$, and $6820 \mu \mathrm{g} / \mathrm{kg}$ at $660-661$ feet are larger than the maximum $\mathrm{x}-\mathrm{scale}$ of $2000 \mu \mathrm{g} / \mathrm{kg}$.

Data are from Appendix B2. [symbols indicate depth in core and Se concentration of rock samples analyzed; lines connecting symbols are for illustration purposes only and do not indicate Se concentrations of rock] 


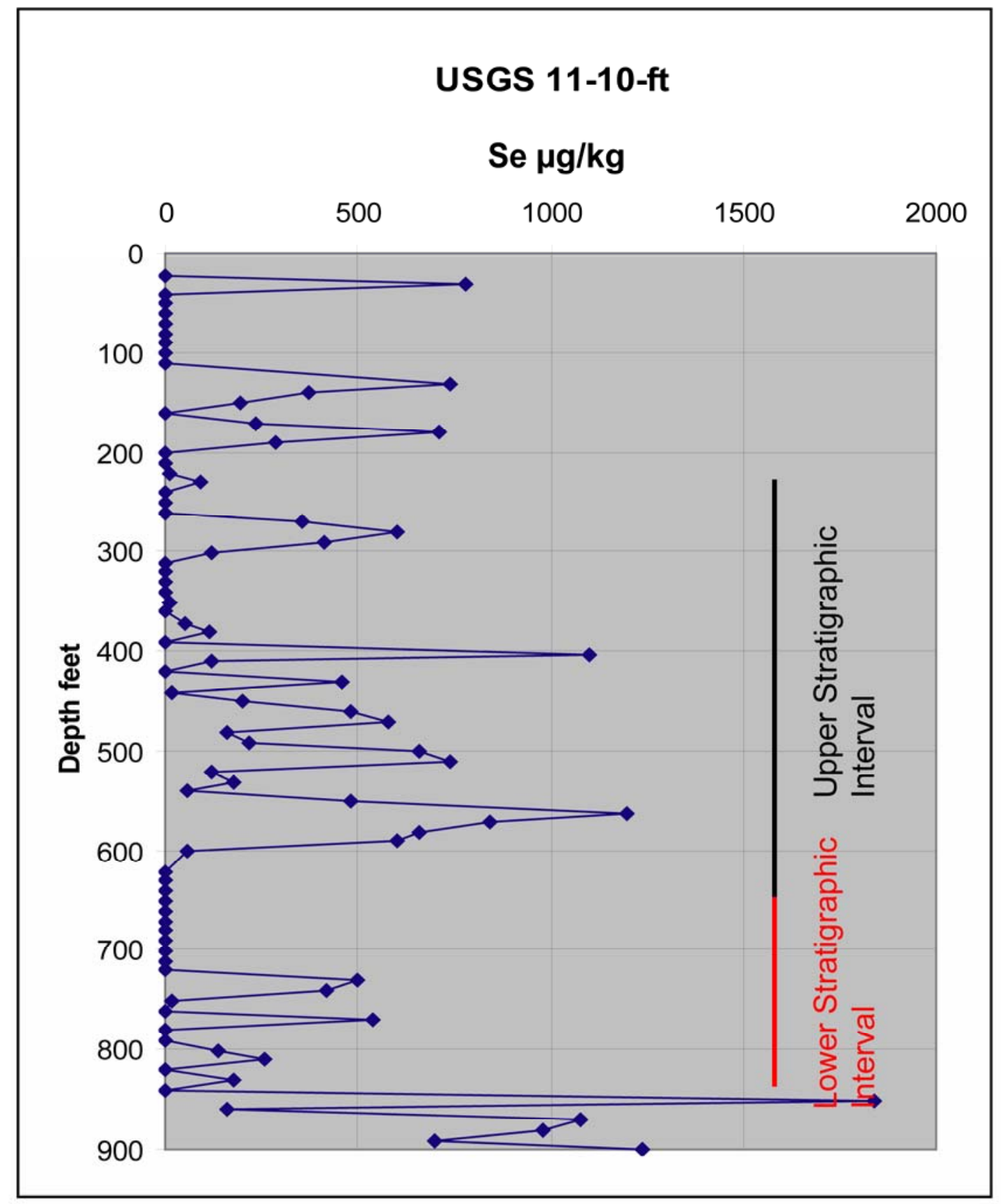

Figure 4. Se concentration $(\mu \mathrm{g} / \mathrm{kg}$ ) versus depth $(\mathrm{ft})$ in core USGS 11-10-ft samples, 1-foot increment samples collected at 10 -foot intervals.

The interval from the base of the Stockton A coal bed (239 feet) down to the top of the Chilton A coal bed (652 feet) is referred to as the upper stratigraphic interval. The interval from the base of the Chilton A coal bed (653 feet) down to the top of the Fire Clay coal bed ( 828 feet) is referred to as the lower stratigraphic interval.

Data are from Appendix B3. [symbols indicate depth in core and Se concentration of rock samples analyzed; lines connecting symbols are for illustration purposes only and do not indicate Se concentrations of rock] 


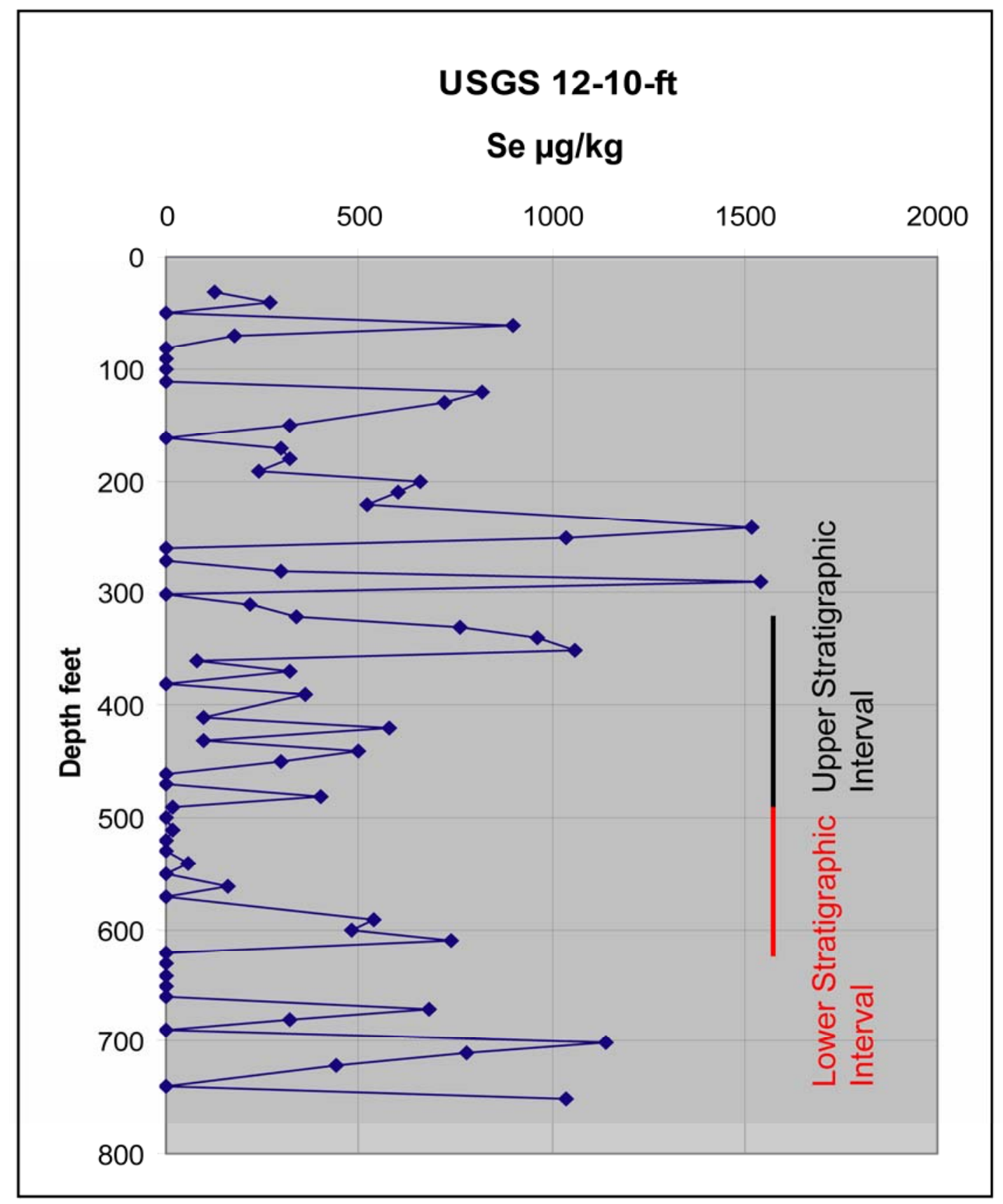

Figure 5. Se concentration $(\mu \mathrm{g} / \mathrm{kg}$ ) versus depth $(\mathrm{ft})$ in core USGS 12-10-ft samples, 1-foot increment samples collected at 10-foot intervals.

The interval from the base of the Stockton A coal bed (316 feet) down to the top of the Chilton A coal bed (492 feet) is referred to as the upper stratigraphic interval. The interval from the base of the Chilton A coal bed (493 feet) down to the top of the Fire Clay coal bed (625 feet) is referred to as the lower stratigraphic interval.

Data are from Appendix B4. [symbols indicate depth in core and Se concentration of rock samples analyzed; lines connecting symbols are for illustration purposes only and do not indicate Se concentrations of rock] 


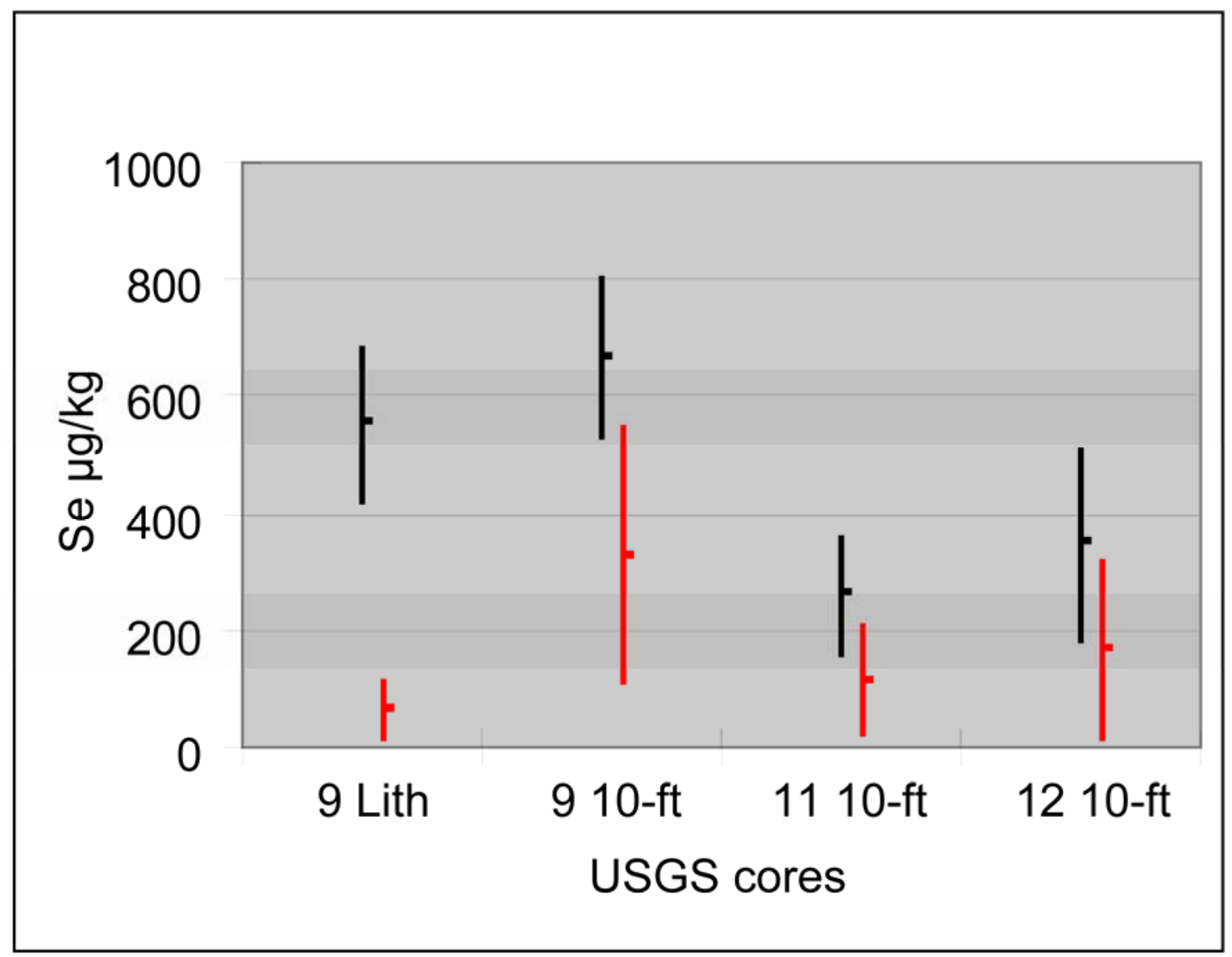

Figure 6. Mean Se concentration $(\mu \mathrm{g} / \mathrm{kg}) \pm 95$ percent confidence interval (CI 95\%) for upper and lower stratigraphic intervals in each core.

Data are from table 4. [upper stratigraphic interval (black), lower stratigraphic interval (red)] 


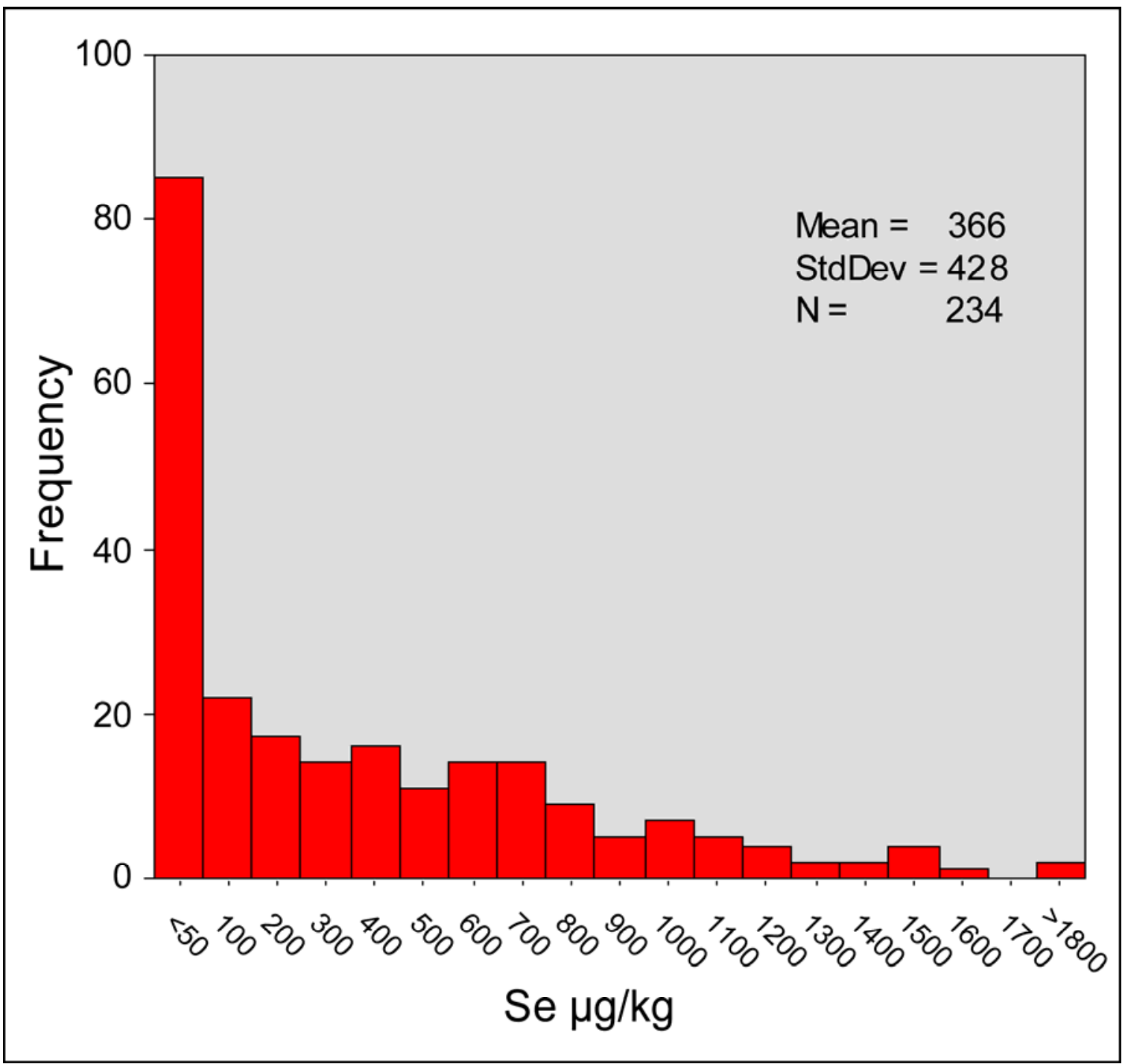

Figure 7. Frequency distribution of Se concentration $(\mu \mathrm{g} / \mathrm{kg})$ for all rock samples collected at 10-foot intervals from USGS 9-10-ft, USGS 11-10-ft, and USGS 12-10-ft.

Two high values for Se concentration (3300 and $6820 \mu \mathrm{g} / \mathrm{kg}$ in USGS 9-10-ft) are not included in mean and standard deviation calculations or shown on this figure. Bins are labeled by mid-point value, except for first bin (values $<50$ ) and last bin (values $>1800$ ).

Data are from Appendices B2, B3, and B4 and are summarized in table 6. [StdDev = standard deviation; $\mathrm{N}=$ number of samples] 


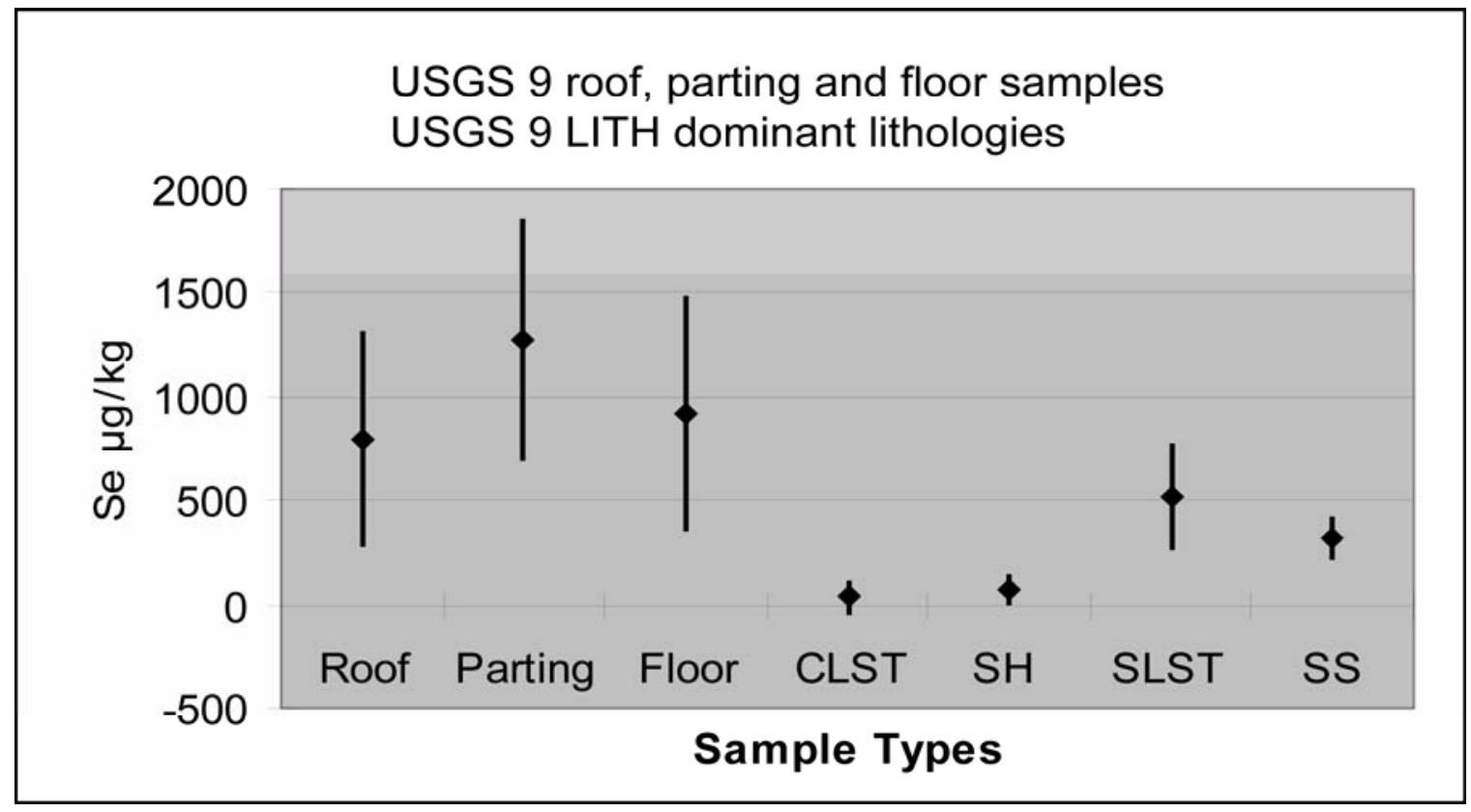

Figure 8. Mean Se concentration $(\mu \mathrm{g} / \mathrm{kg}) \pm 95$ percent confidence interval (Cl $95 \%$ ) for four dominant lithologies from USGS 9-LITH and roof, parting, and floor samples from core USGS 9.

The rank-order of the mean Se concentrations for the seven sample types is: parting $>$ floor $>$ roof $>$ siltstone $>$ sandstone $>$ shale $>$ claystone.

Data are from tables 7 and 8. [CLST $=$ claystone, $\mathrm{SH}=$ shale, $\mathrm{SLST}=$ siltstone, $\mathrm{SS}=$ sandstone] 


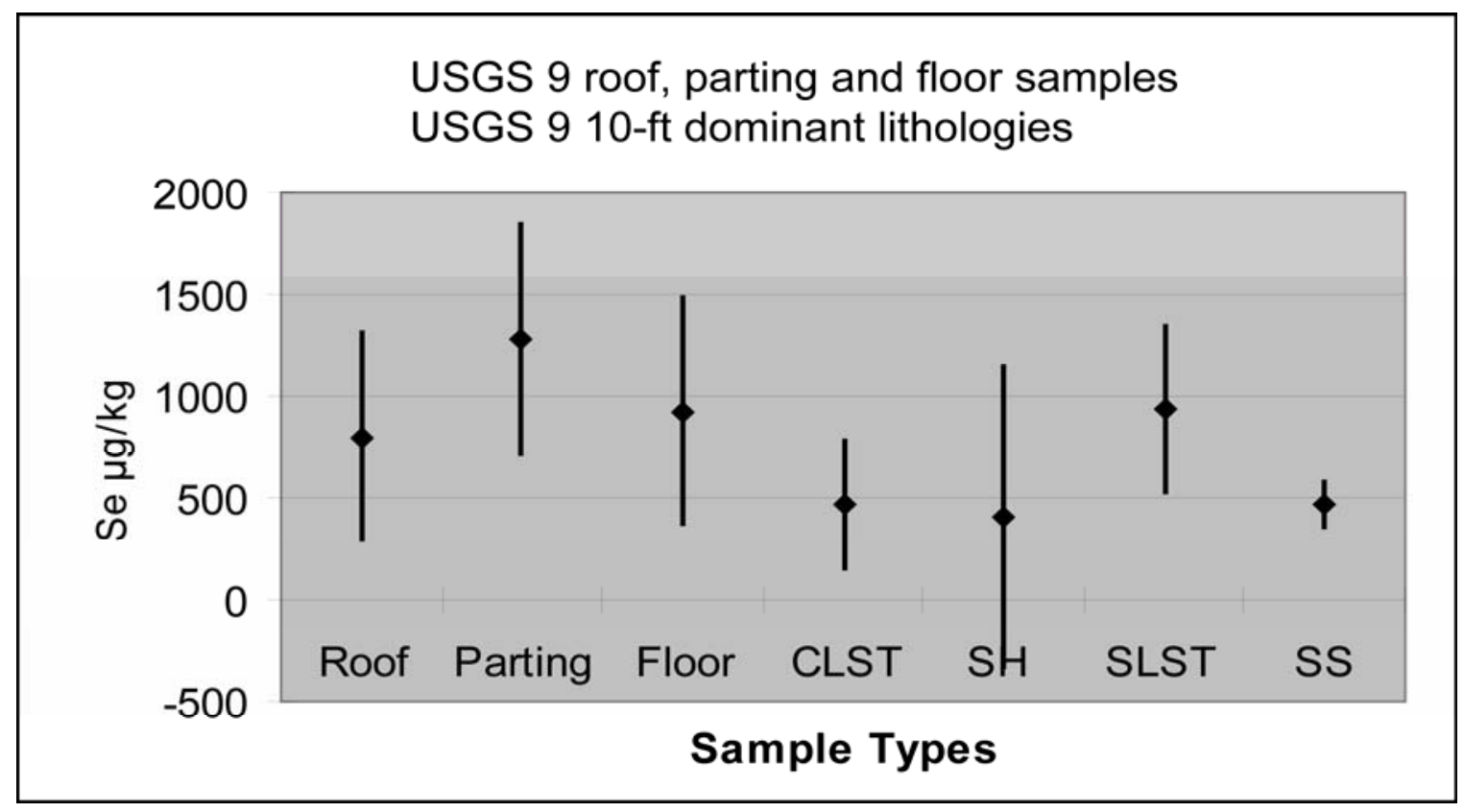

Figure 9. Mean Se concentration $(\mu \mathrm{g} / \mathrm{kg}) \pm 95$ percent confidence interval $(\mathrm{Cl} 95 \%)$ for four dominant lithologies from USGS 9-10-ft and roof, parting, and floor samples from core USGS 9.

The rank-order of the mean Se concentrations for the seven sample types is: parting $>$ siltstone $>$ floor $>$ roof $>$ sandstone $>$ claystone $>$ shale.

Data are from tables 7 and 8. [CLST $=$ claystone, $\mathrm{SH}=$ shale, $\mathrm{SLST}=$ siltstone, $\mathrm{SS}=$ sandstone] 


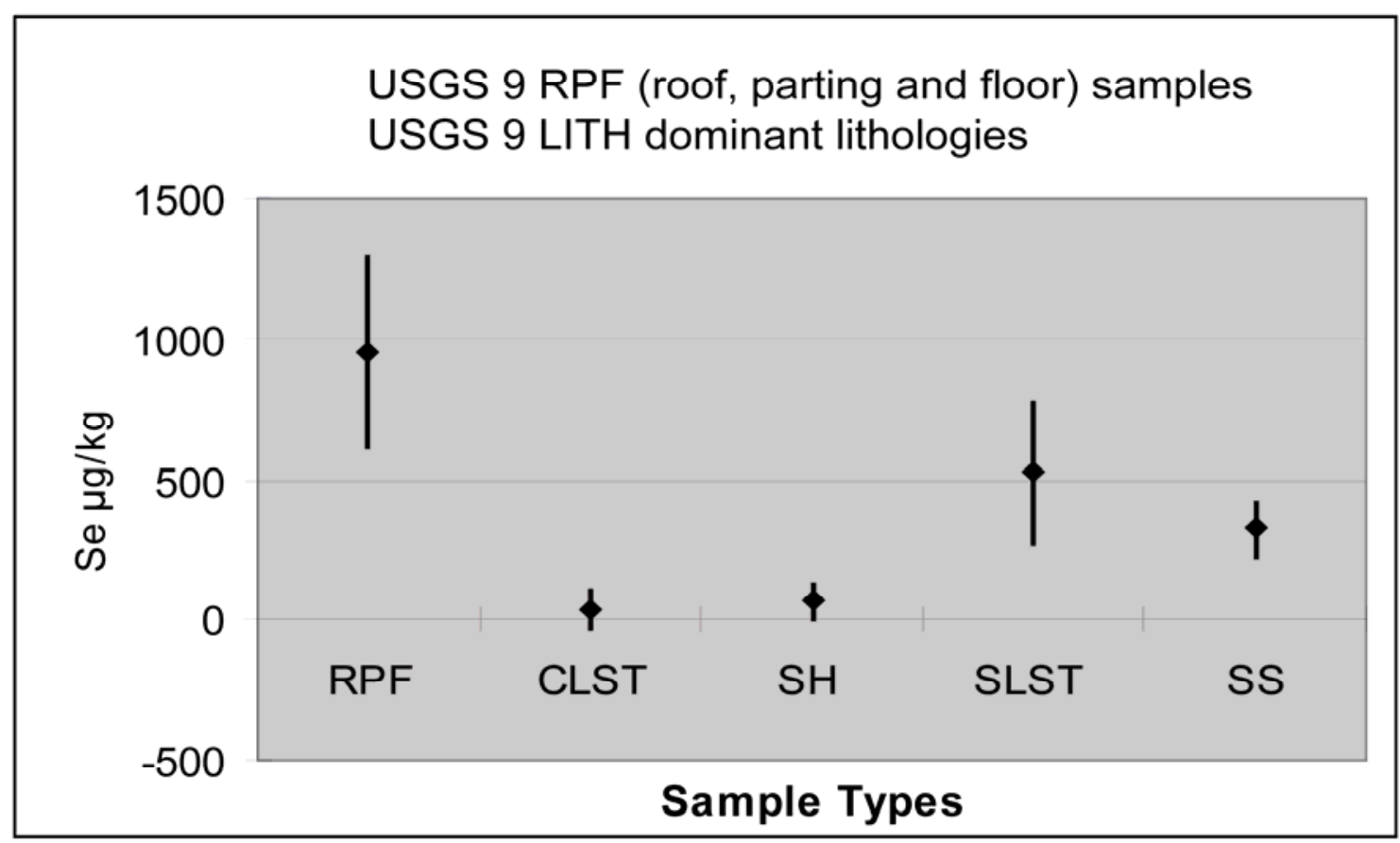

Figure 10. Mean Se concentration $(\mu \mathrm{g} / \mathrm{kg}) \pm 95$ percent confidence interval (CI 95\%) for four dominant lithologies from USGS 9-LITH and USGS 9-RPF (combined roof, parting, and floor samples from core USGS 9).

Statistical t-rests show that the mean Se concentration of RPF (952) is equal to the mean for siltstone (523) and greater than the means for claystone (33), shale (65), and sandstone (322).

Data are from tables 7, 9, and 10. [CLST = claystone, $\mathrm{SH}=$ shale, $\mathrm{SLST}=$ siltstone, $\mathrm{SS}=$ sandstone $]$ 


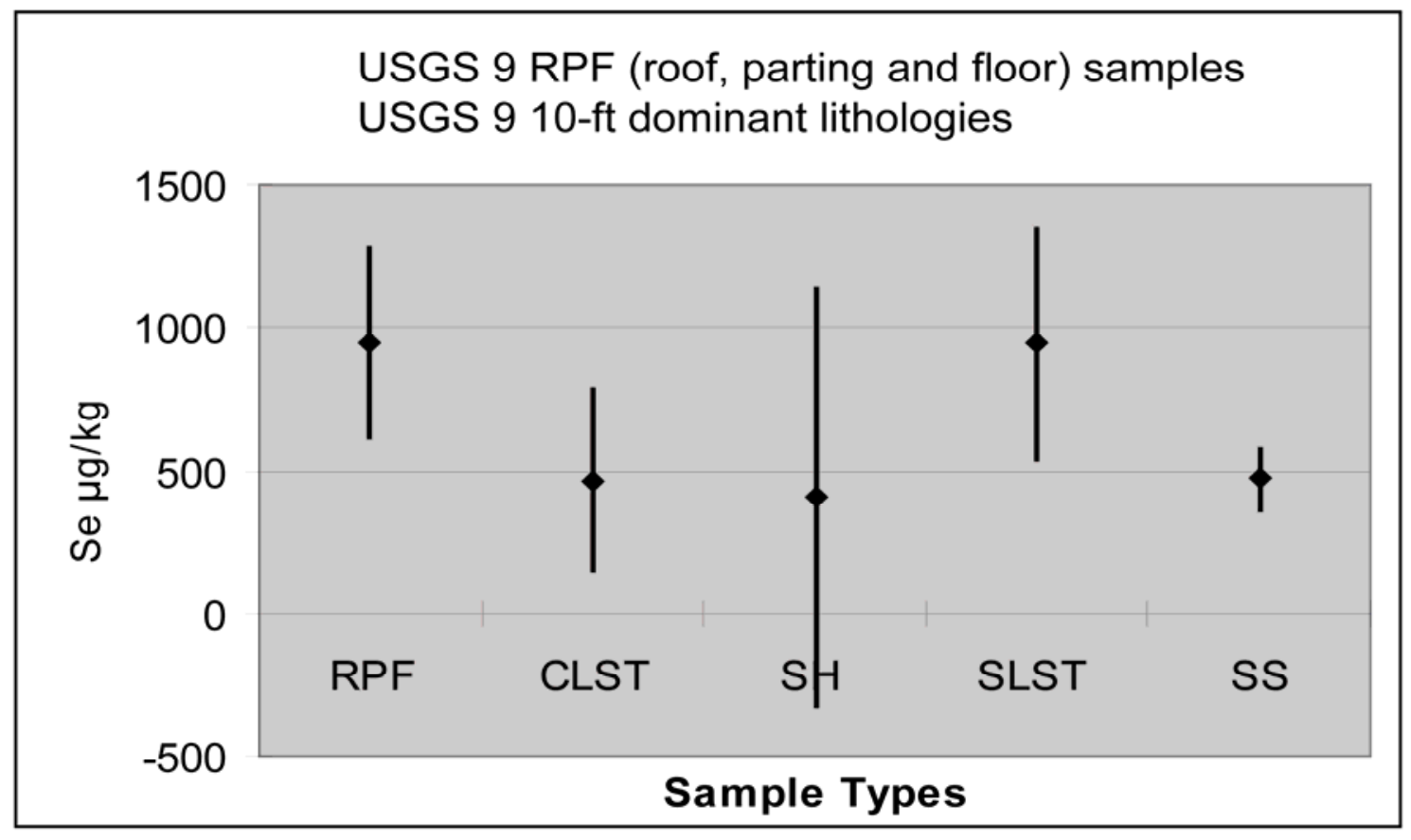

Figure 11. Mean Se concentration $(\mu \mathrm{g} / \mathrm{kg}) \pm 95$ percent confidence interval (CI 95\%) for four dominant lithologies from USGS 9-10-ft and USGS 9-RPF (combined roof, parting, and floor samples from core USGS 9).

Statistical t-tests show that the mean Se concentration of RPF (952) is equal to the means for shale (405) and siltstone (943) and greater than the means for claystone (464) and sandstone (467).

Data are from tables 7, 9, and 10. [CLST = claystone, $\mathrm{SH}=$ shale, $\mathrm{SLST}=$ siltstone, $\mathrm{SS}=$ sandstone $]$ 


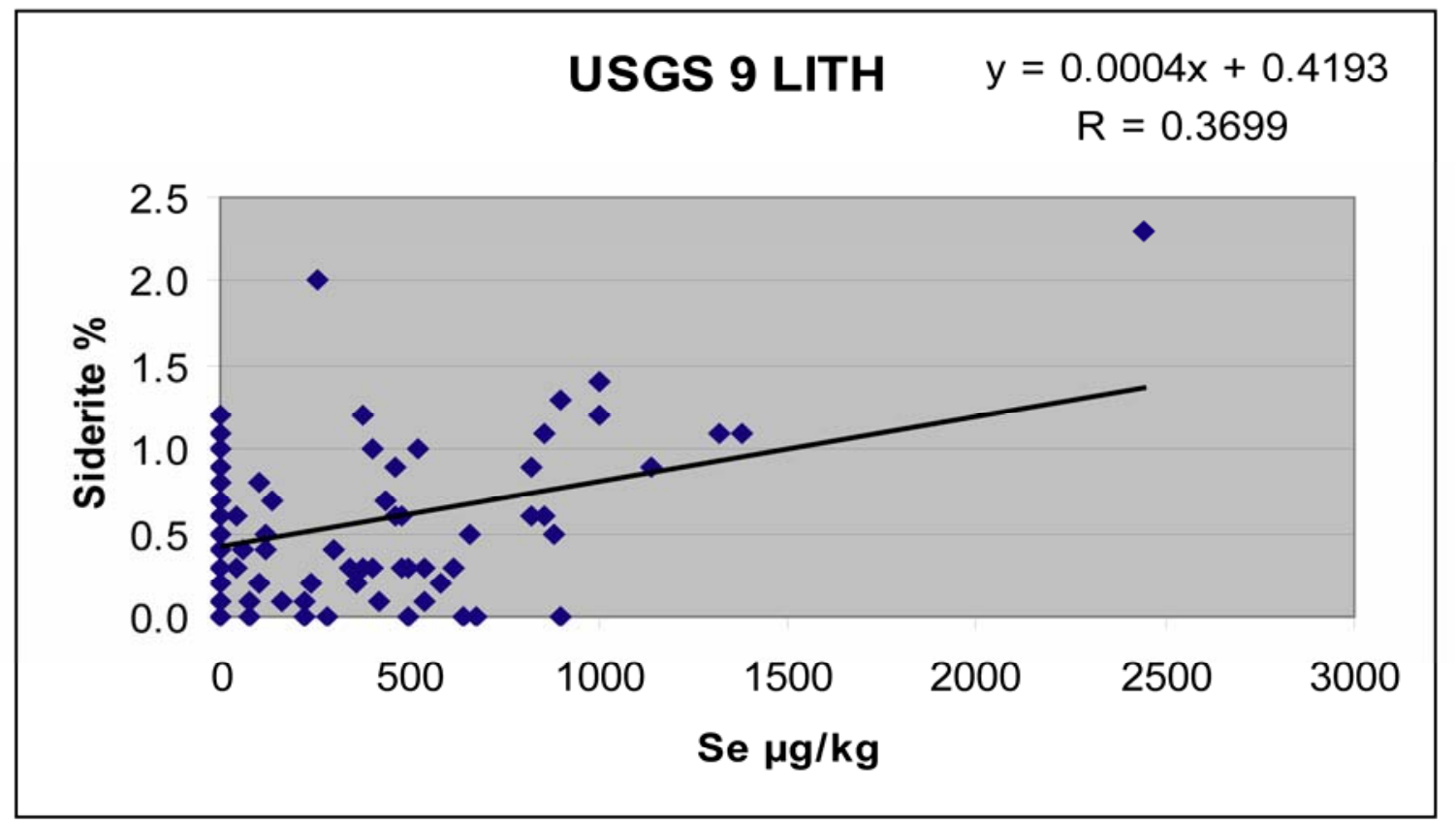

Figure 12. Se concentration $(\mu \mathrm{g} / \mathrm{kg}$ ) versus siderite (percent) in USGS 9-LITH.

Data are from Appendices B1 and B5. 

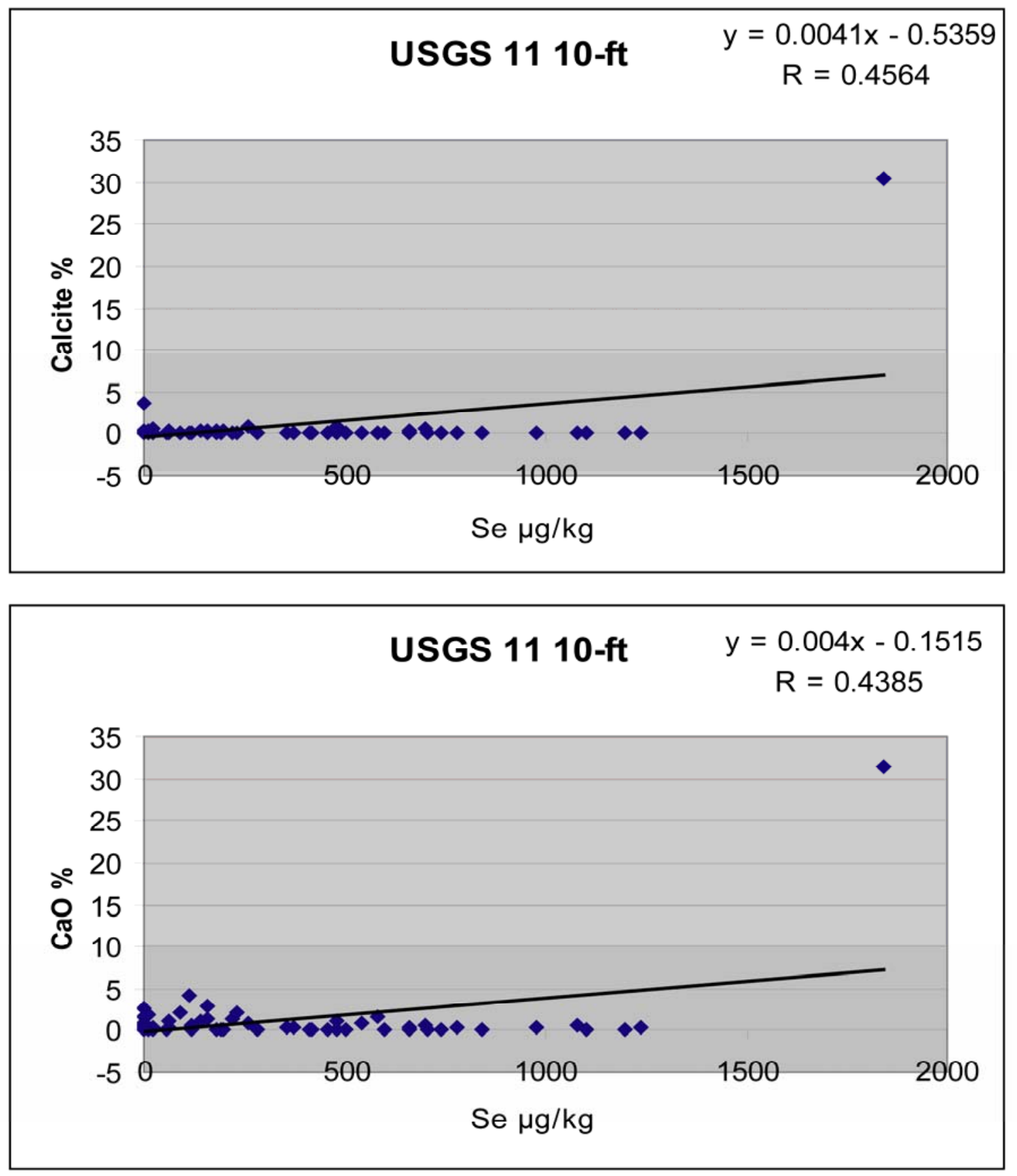

Figure 13. Se concentration ( $\mu \mathrm{g} / \mathrm{kg}$ ) versus calcite and $\mathrm{CaO}$ (percent) in USGS 11-10-ft.

Upon removal of the point with high Se and high calcite the $\mathrm{R}$ value becomes 0.0762 and the correlation is no longer significant. Upon removal of the point with high $\mathrm{Se}$ and high $\mathrm{CaO}$ the $\mathrm{R}$ value becomes 0.10 and the correlation is no longer significant.

Data are from Appendices B3 and B7. 

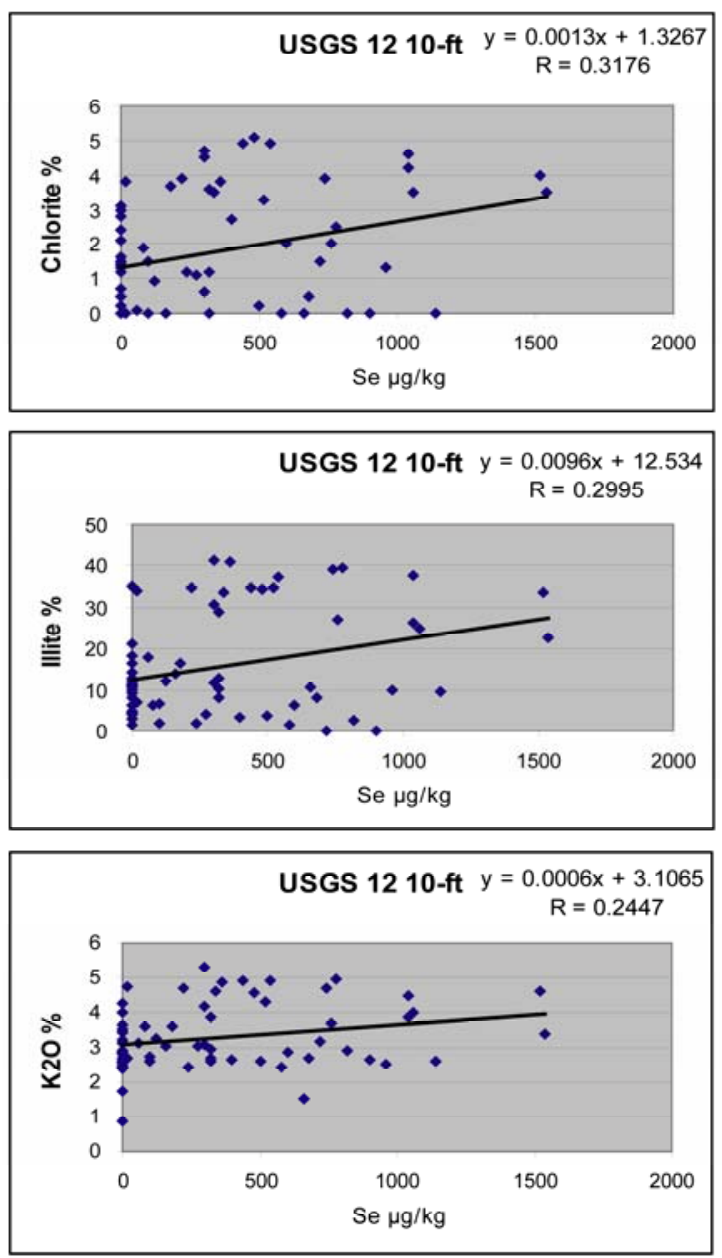

Figure 14. Se concentration $\left(\mu \mathrm{g} / \mathrm{kg}\right.$ ) versus chlorite, kaolinite, illite, calcite, and $\mathrm{K}_{2} \mathrm{O}$ (percent) in USGS 12-10-ft.

Data are from Appendices B4 and B8.
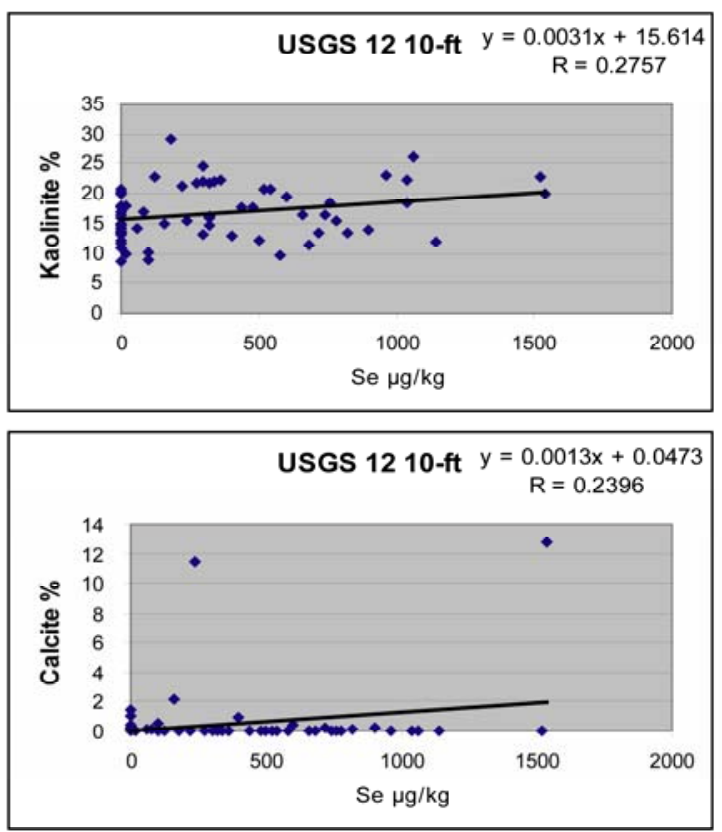


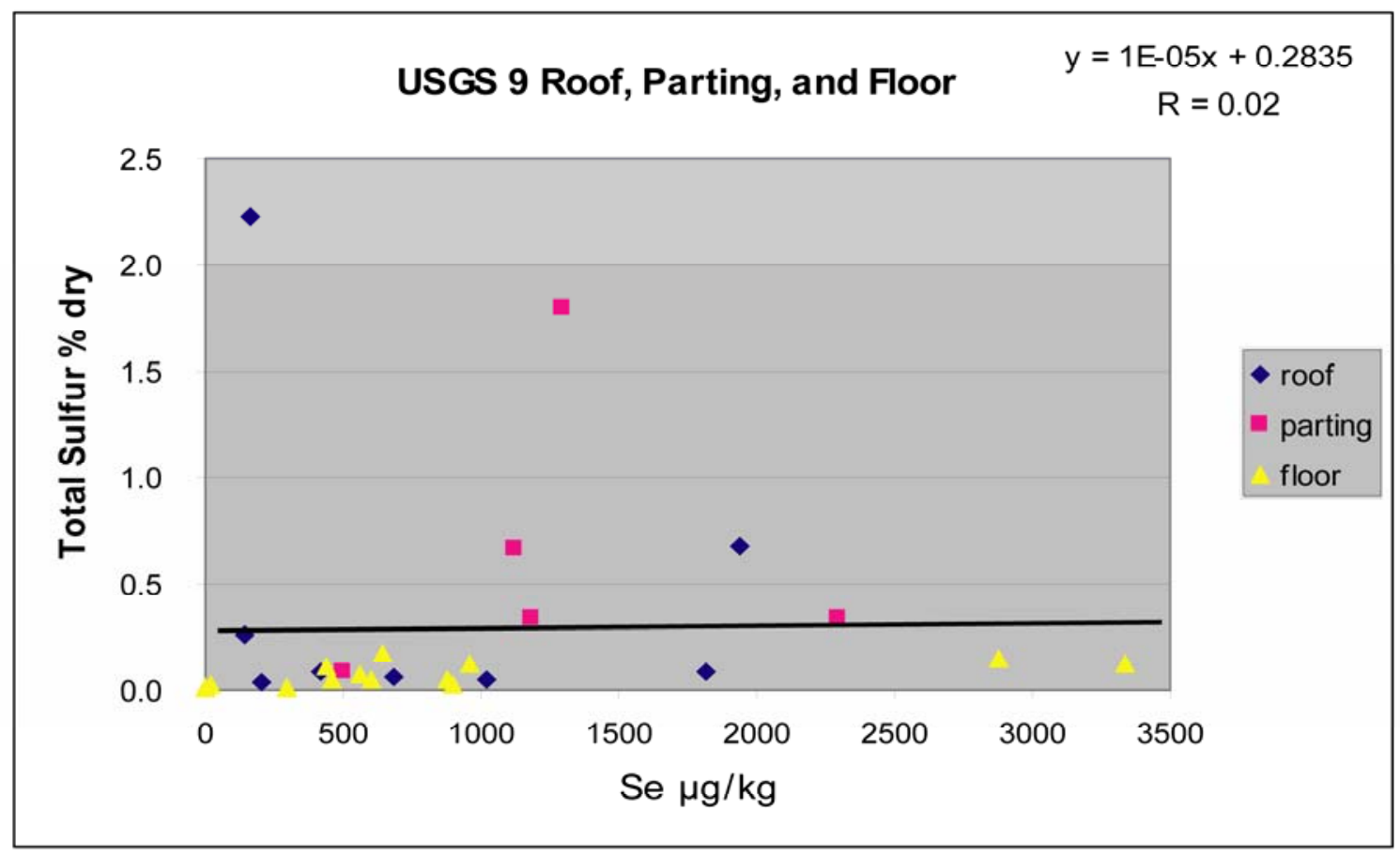

Figure 15. Se concentration ( $\mu \mathrm{g} / \mathrm{kg}$ ) versus total sulfur (percent, dry basis) in roof, parting, and floor samples from USGS 9.

Data are from Appendix B9. 


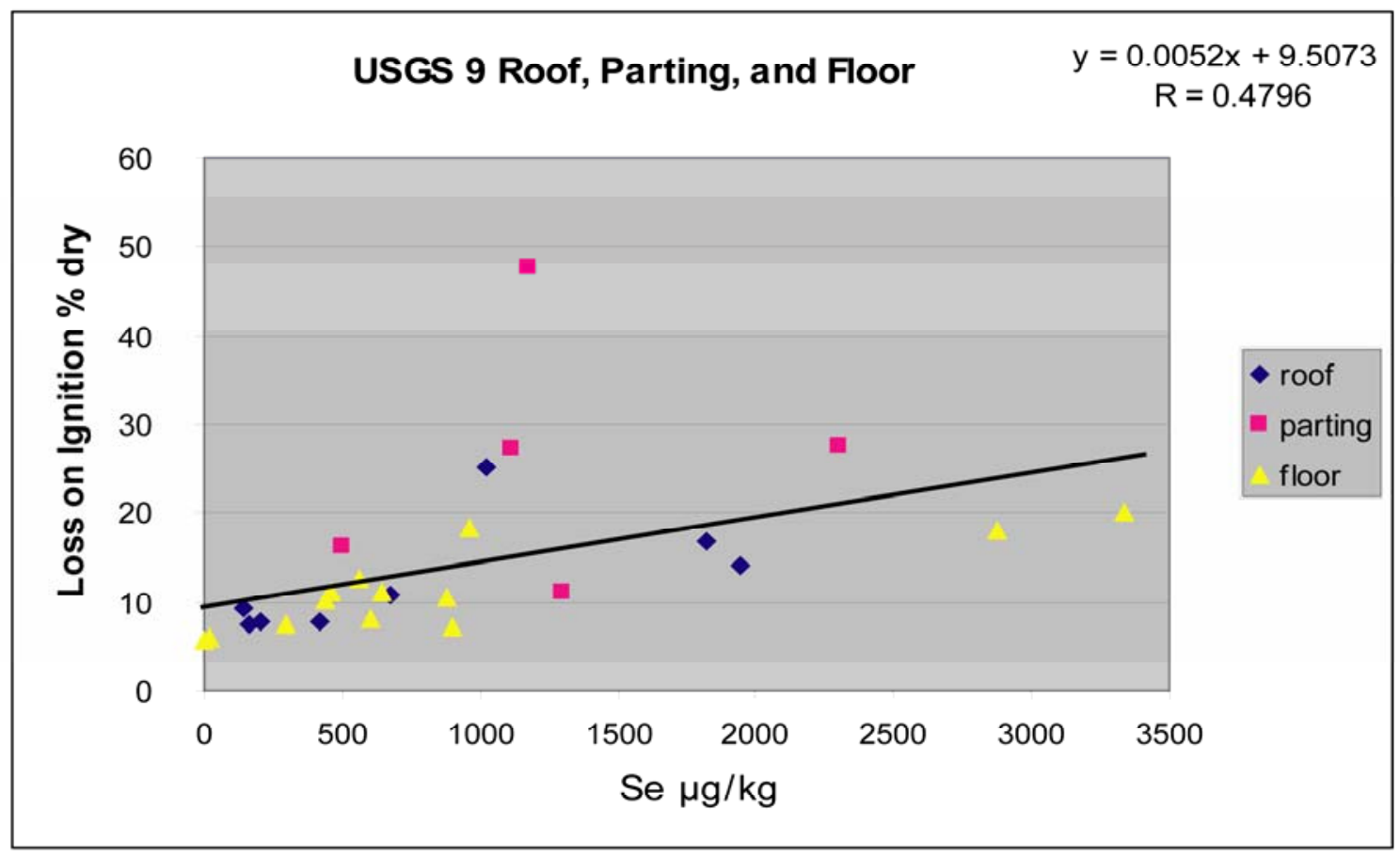

Figure 16. Se concentration $(\mu \mathrm{g} / \mathrm{kg}$ ) versus loss on ignition (percent, dry basis) in roof, parting, and floor samples from USGS 9.

Data are from Appendix B9. 


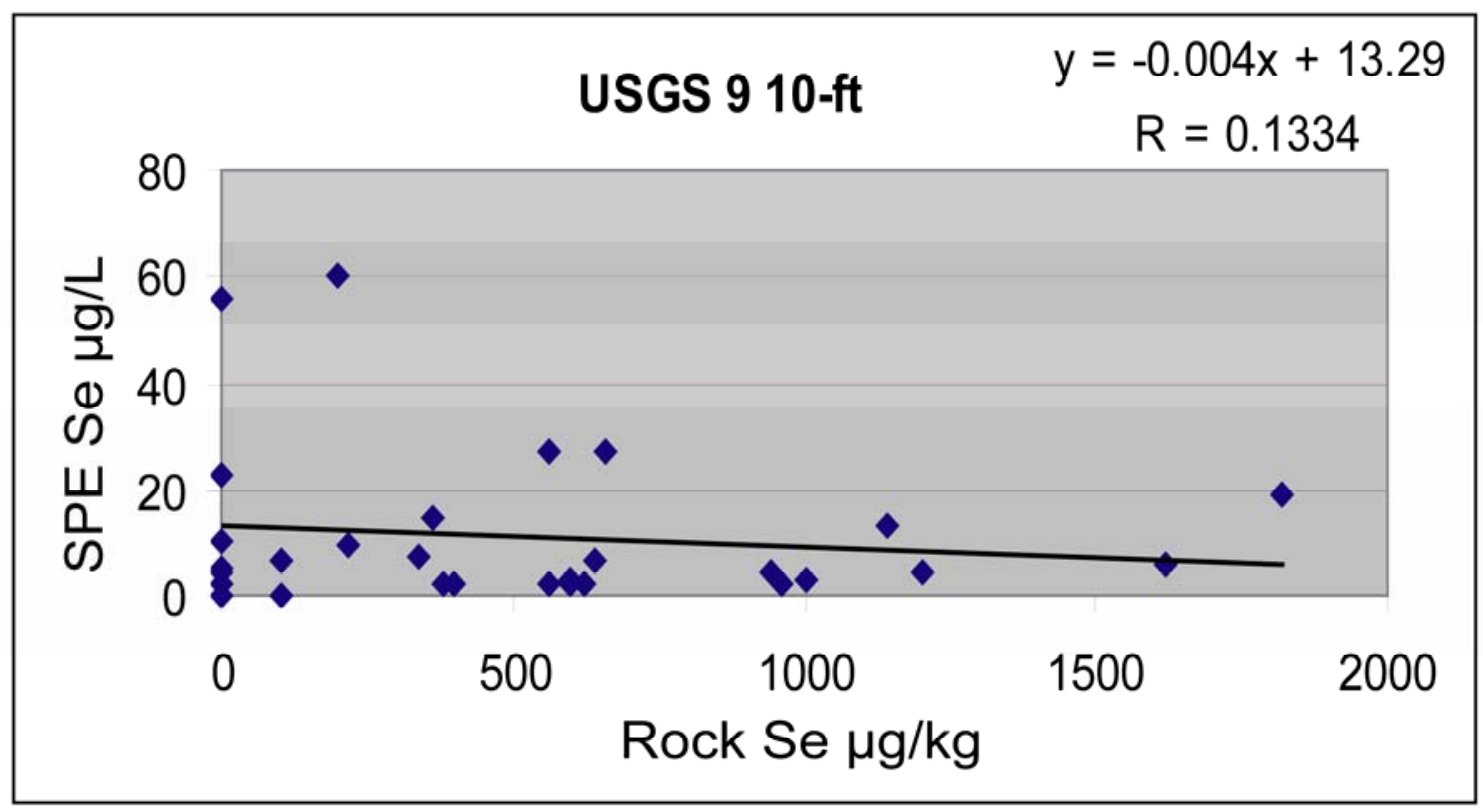

Figure 17. Se concentration $(\mu \mathrm{g} / \mathrm{L})$ in saturated paste extract $(\mathrm{SPE})$ versus Se concentration $(\mu \mathrm{g} / \mathrm{kg})$ in rock samples from USGS 9-10-ft.

Two high Se values in rock (3300 and $6820 \mu \mathrm{g} / \mathrm{kg}$ ) are not plotted and the correlation coefficient $(\mathrm{R}=0.1334)$ is not significant. If the two high Se values are included, the correlation coefficient is not significant either.

Data are from Appendices B2 and B10.

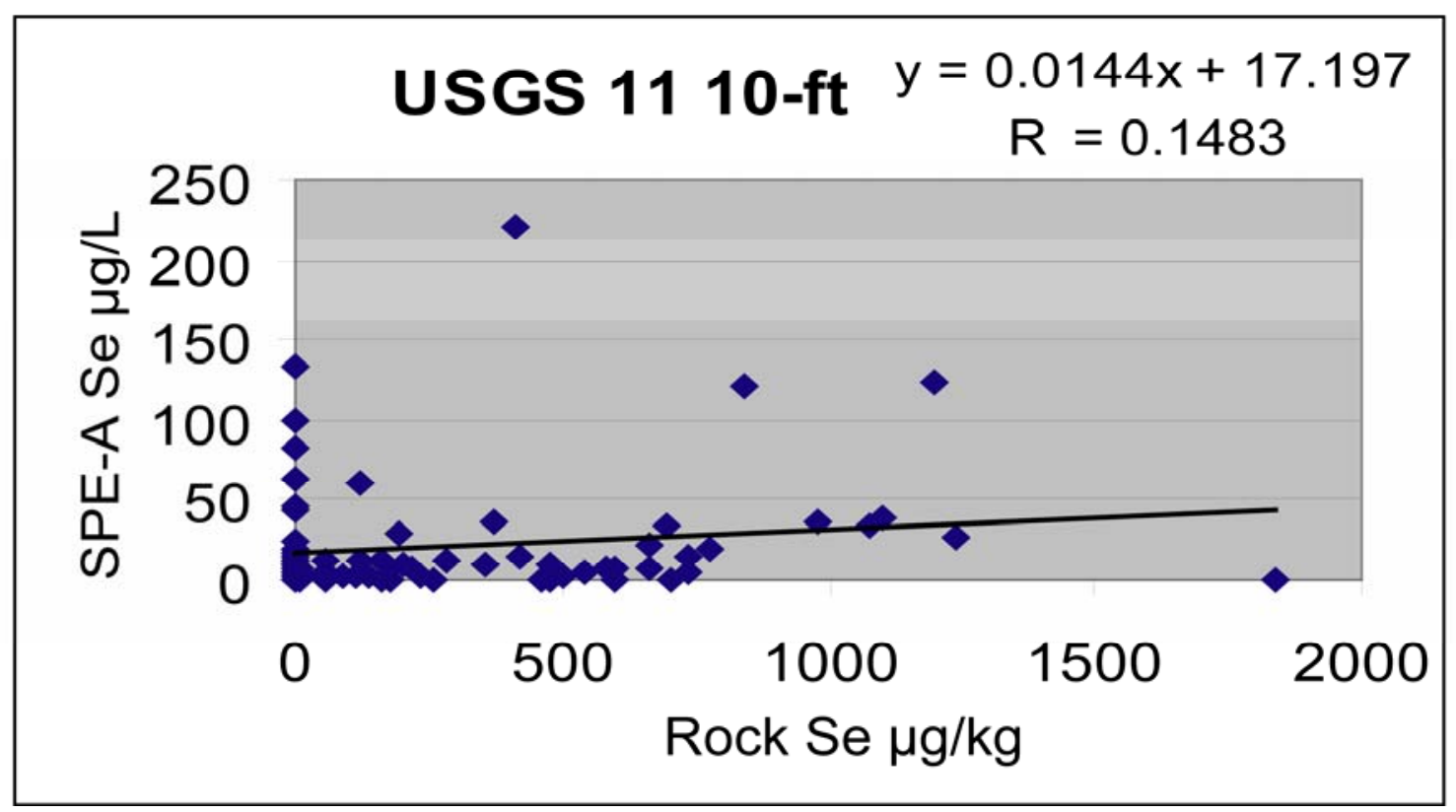

Figure 18. Se concentration $(\mu \mathrm{g} / \mathrm{L})$ in saturated paste extract $(S P E-A)$ versus Se concentration $(\mu \mathrm{g} / \mathrm{kg})$ in rock samples from USGS 11-10-ft.

Data are from Appendices B3 and B11. 


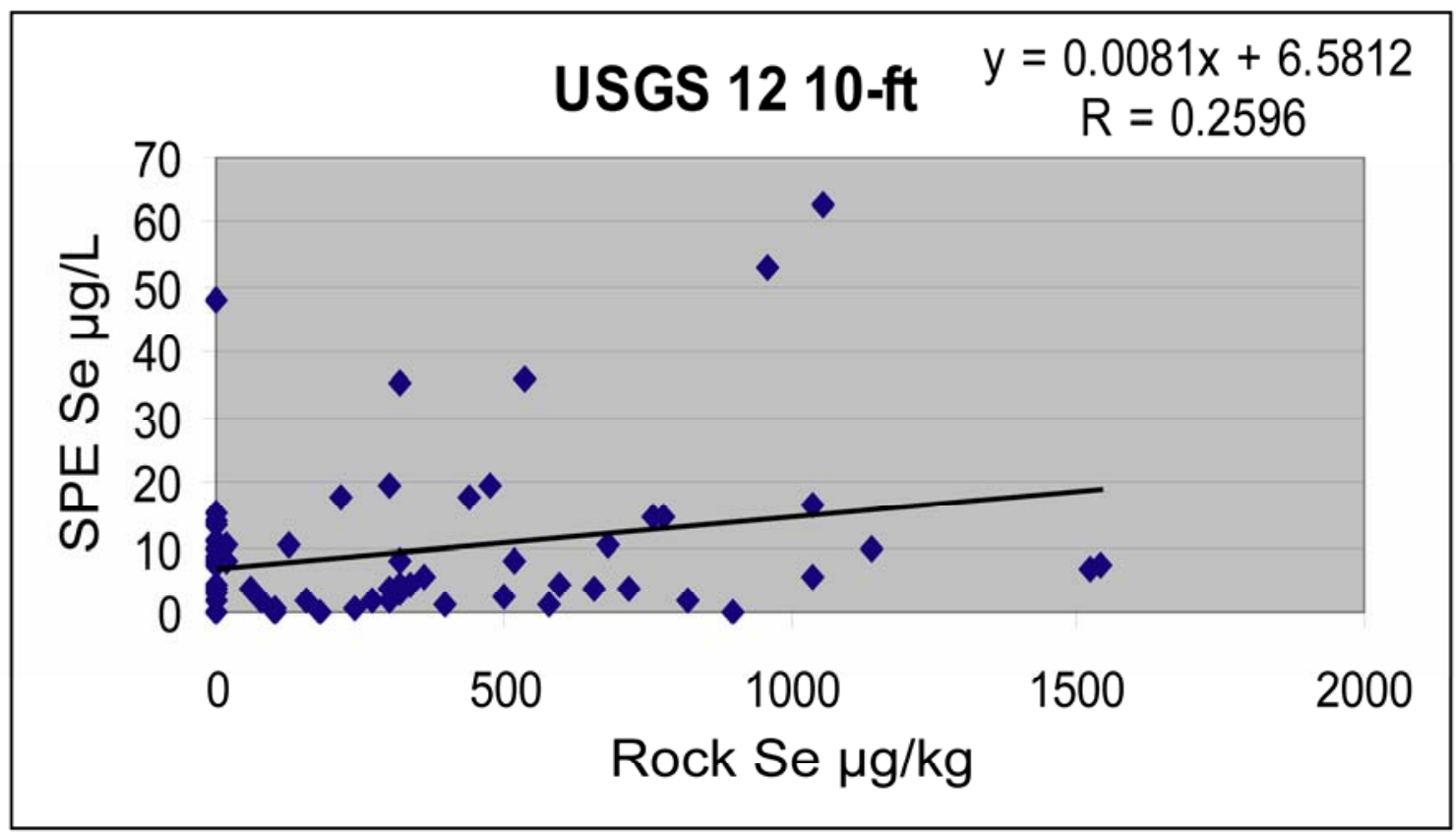

Figure 19. Se concentration $(\mu \mathrm{g} / \mathrm{L})$ in saturated paste extract (SPE) versus Se concentration $(\mu \mathrm{g} / \mathrm{kg})$ in rock samples from USGS 12-10-ft.

Data are from Appendices B4 and B12.

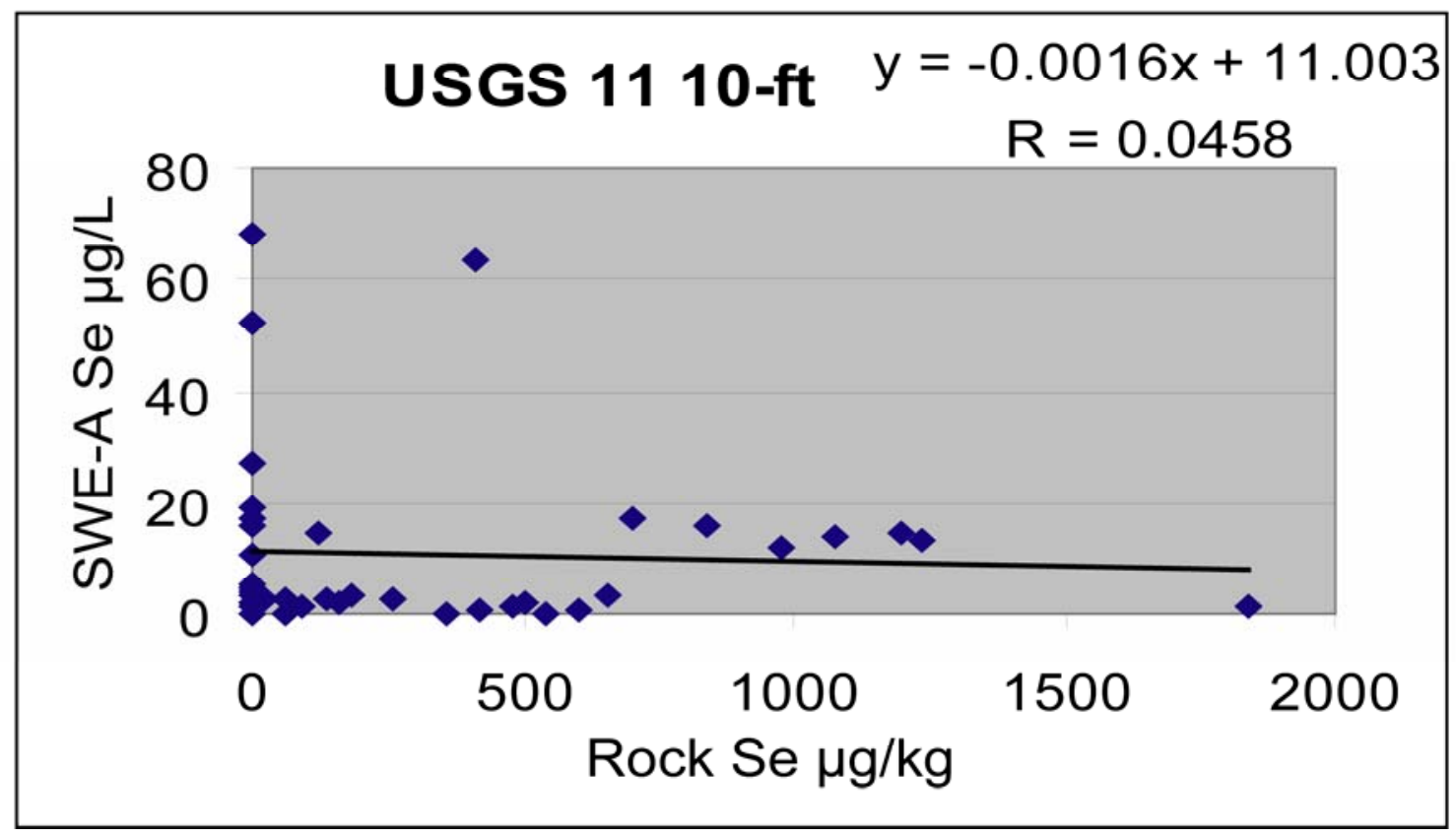

Figure 20. Se concentration $(\mu \mathrm{g} / \mathrm{L})$ in sequential water extraction first extract (SWE-A) versus Se concentration $(\mu \mathrm{g} / \mathrm{kg})$ in rock samples from USGS 11-10-ft.

Data are from Appendices B3 and B13. 


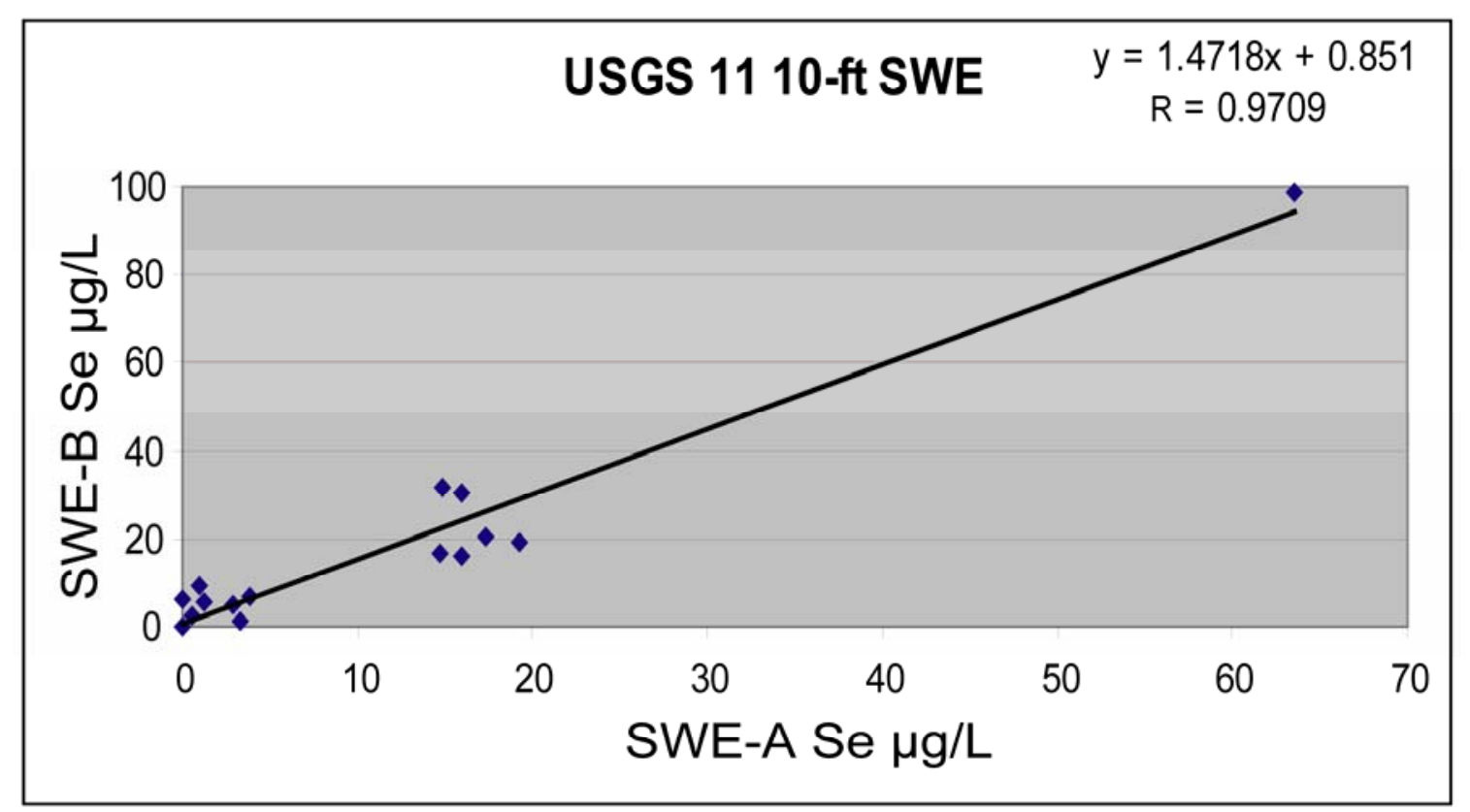

Figure 21. Se concentration $(\mu \mathrm{g} / \mathrm{L})$ in sequential water extraction first extract of rock sub-sample $A$ (SWE-A) versus Se concentration ( $\mu \mathrm{g} / \mathrm{L})$ in sequential water extraction first extract of rock subsample B (SWE-B) for USGS 11-10-ft samples.

Data are from Appendix B13.

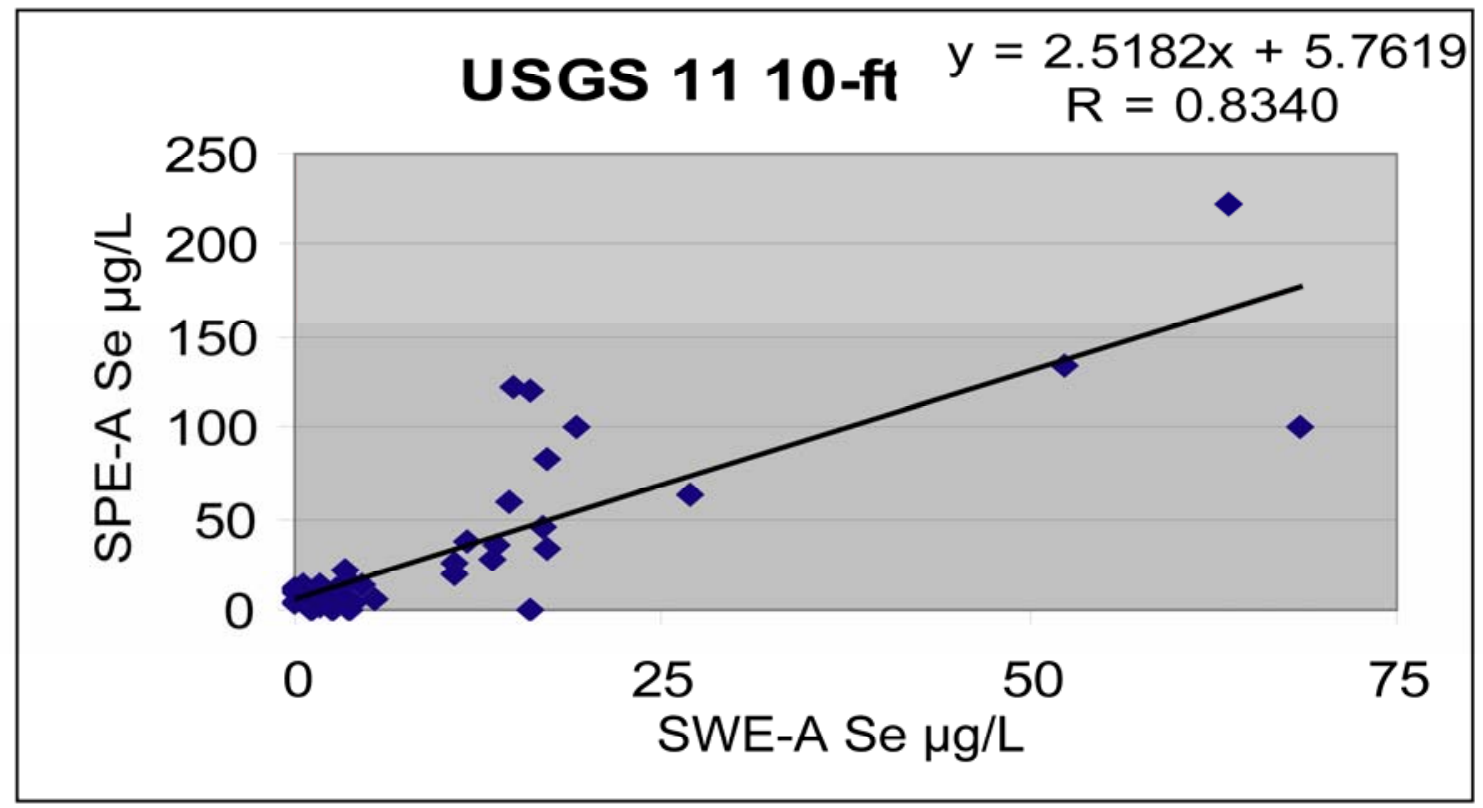

Figure 22. Se concentration $(\mu \mathrm{g} / \mathrm{L})$ in saturated paste extract (SPE-A) versus Se concentration $(\mu \mathrm{g} / \mathrm{L})$ in sequential water extraction first extract (SWE-A) for duplicate sub-samples of rock from USGS 11-10-ft.

Data are from Appendices B11 and B13. 


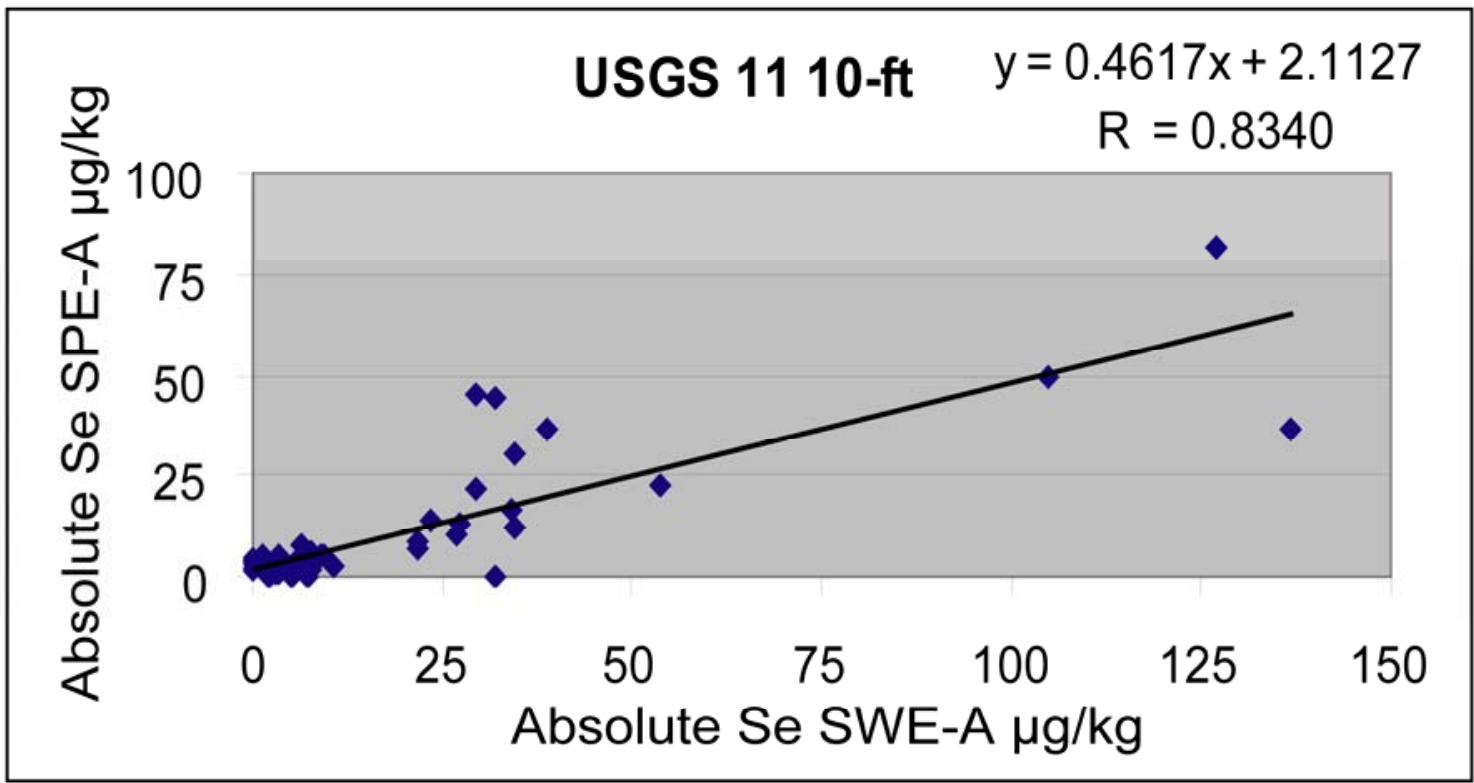

Figure 23. Absolute Se ( $\mu \mathrm{g}$ Se in solution / $\mathrm{kg}$ of rock leached) in saturated paste extract (SPE-A) versus absolute $\mathrm{Se}$ ( $\mu \mathrm{g} \mathrm{Se}$ in solution / $\mathrm{kg}$ of rock leached) in sequential water extraction first extract (SWE-A) for duplicate sub-samples of rock from USGS 11-10-ft.

Data are calculated from Appendices B11 and B13. 


\section{USGS 11 10-ft SWE}

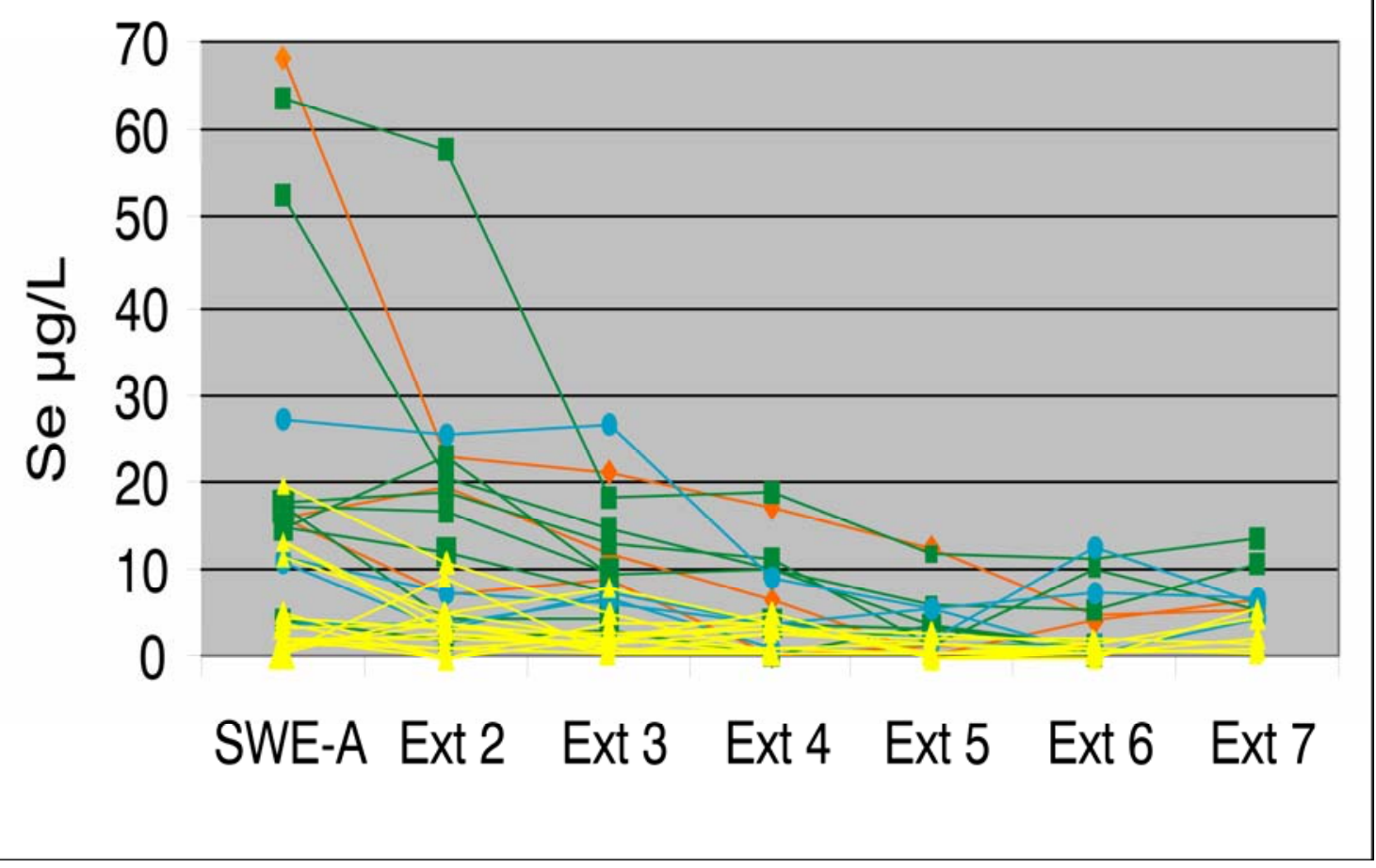

Figure 24. Se concentration ( $\mu \mathrm{g} / \mathrm{L}$ ) in sequential water extractions (SWE-) for up to 7 sequential extractions of a rock sample, for samples from USGS 11-10-ft.

SWE-A is the first extract followed by 2nd, 3rd, 4th, 5th, 6th, and 7th extracts of the same rock material.

Data are from Appendix B13. $[$ claystone $=$ orange, shale $=$ green, siltstone $=$ blue , and sandstone $=$ yellow $]$ 
Table 1. Trace element concentrations for 13 elements, including Se, reported in ASTM 3052 with certification by National Institute of Standards and Technology (NIST) for standard reference material (SRM) 2704

ASTM and NIST report the mean concentration and the 95 percent confidence interval (CI 95\%) for each element. A normalized metric that is used in this study to indicate precision of results, is the CI 95\% divided by the mean concentration. Data are from ASTM 3052 (1996), also available on the web at $h t t p ; / / w w w . e p a . g o v / s w-846 / p d f s / 3052 . p d f$.

[values in parens ( ) are not certified; --- = not analyzed or not reported]

\begin{tabular}{|c|c|c|c|c|c|c|c|}
\hline \multirow[b]{2}{*}{ Element } & \multirow[b]{2}{*}{ Count } & \multicolumn{2}{|c|}{ ASTM Analyzed } & \multicolumn{2}{|c|}{ NIST Analyzed } & \multirow{2}{*}{$\begin{array}{c}\text { ASTM } \\
\text { Cl:Mean }\end{array}$} & \multirow{2}{*}{$\begin{array}{c}\text { NIST } \\
\text { Cl } \div \text { Mean }\end{array}$} \\
\hline & & Mean $\mu \mathrm{g} / \mathrm{g}$ & CI $95 \%$ & Mean $\mu \mathrm{g} / \mathrm{g}$ & CI 95\% & & \\
\hline As & 4 & 23.4 & 2.6 & 23.4 & 0.8 & 0.11 & 0.03 \\
\hline $\mathrm{Cd}$ & 6 & 3.5 & 1.2 & 3.45 & 0.22 & 0.34 & 0.06 \\
\hline $\mathrm{Cr}$ & 6 & 132.9 & 1.3 & 135 & 5 & 0.01 & 0.04 \\
\hline $\mathrm{Cu}$ & 6 & 98.0 & 4.2 & 98.6 & 5.0 & 0.04 & 0.05 \\
\hline $\mathrm{Pb}$ & 6 & 155 & 9.2 & 161 & 17 & 0.06 & 0.11 \\
\hline $\mathrm{Hg}$ & 4 & 1.49 & 0.14 & 1.44 & 0.07 & 0.09 & 0.05 \\
\hline $\mathrm{Ni}$ & 6 & 43.6 & 3.9 & 44.1 & 3.0 & 0.09 & 0.07 \\
\hline $\mathrm{P}$ & 4 & 1016 & 16 & 998 & 28 & 0.02 & 0.03 \\
\hline $\mathrm{Se}$ & 4 & 1.13 & 0.9 & (1.1) & -- & 0.80 & --- \\
\hline$S$ & 4 & 3.56 & 0.16 & -- & --- & 0.04 & --- \\
\hline $\mathrm{Tl}$ & 4 & 1.15 & 0.22 & 1.2 & 0.2 & 0.19 & 0.17 \\
\hline $\mathrm{U}$ & 4 & 2.97 & 0.04 & 3.13 & 0.13 & 0.01 & 0.04 \\
\hline $\mathrm{Zn}$ & 6 & 441.9 & 0.8 & 438 & 12 & 0.002 & 0.03 \\
\hline
\end{tabular}


Table 2. Comparison of Se concentration in 12 samples coincident to both USGS 9-LITH and USGS 9-10-ft

The table indicates that the Se concentrations for samples selected by lithology (USGS 9-LITH) tend to be lower than the Se concentrations for samples collected at 10-foot intervals (USGS 9-10-ft). The correlation coefficient $(\mathrm{R}=0.6712)$ is significant at the 0.05 level. However, the correlation is not significant at the 0.01 level. In order to test the equality of the means (mean Se concentration in USGS 9-LITH and mean Se concentration in USGS 9-10-ft), the variances must first be evaluated for equality with an F-test. Depending on the outcome of the F-test, either the variances are equal (E) or they are unequal (UE). Then a t-test tests for equality of the means (using the appropriate $t$-value for either equal or unequal variances) to determine if the means are equal (E) or unequal (UE). The variance of Se concentrations in USGS 9-LITH samples is equal to the variance of Se concentrations in USGS 9-10-ft samples. The mean Se concentration of USGS 9-LITH samples is equal to the mean Se concentration of USGS 9-10-ft samples.

[data are from Appendices B1 and B2; StdDev = standard deviation; ND = not detected and a value of 0 was used in calculations]

\begin{tabular}{ccccl}
\hline $\begin{array}{c}\text { Sample ID } \\
\text { interval ft }\end{array}$ & $\begin{array}{c}\text { USGS 9 } \\
\text {-LITH } \\
\text { Se } \boldsymbol{\mu g} / \mathbf{k g}\end{array}$ & $\begin{array}{c}\text { USGS 9 } \\
\mathbf{- 1 0 - f t} \\
\mathbf{S e ~} \boldsymbol{\mu g} / \mathbf{k g}\end{array}$ & $\begin{array}{c}\text { USGS 9 } \\
\text {-LITH vs } \\
\mathbf{9 - 1 0 - f t}\end{array}$ & Lithology \\
\hline $163-163$ & 540 & 740 & Lower & Siltstone \\
$170-171$ & 100 & 700 & Lower & Siltstone \\
$280-281$ & 1140 & 1440 & Lower & Siltstone \\
$340-341$ & 640 & 580 & Higher & Sandstone \\
$390-391$ & 480 & 20 & Higher & Sandstone \\
$430-431$ & ND & 400 & Lower & Sandstone \\
$460-461$ & ND & ND & ND & Mudstone \\
$560-561$ & 380 & 1520 & Lower & Shale \\
$570-571$ & 120 & ND & Higher & Shale \\
$580-581$ & ND & ND & ND & Sandstone \\
$600-601$ & ND & 140 & Lower & Claystone \\
$650-651$ & ND & 180 & Lower & Sandstone \\
& & & & \\
\hline
\end{tabular}

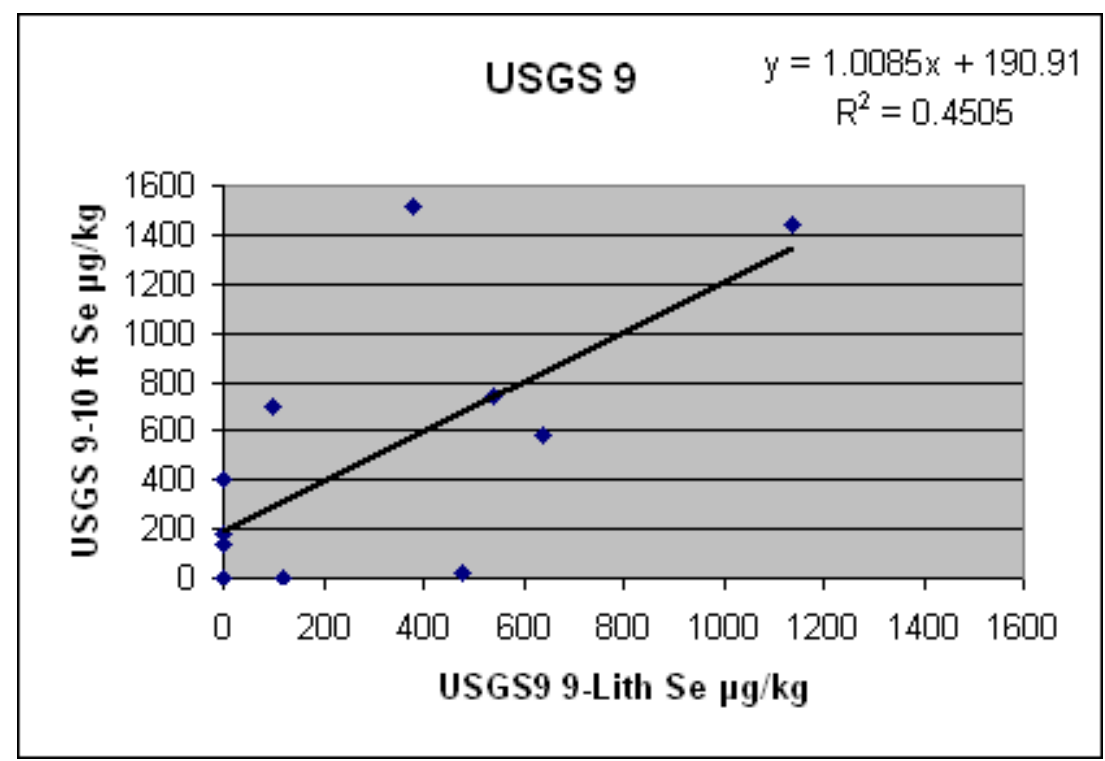


Table 2. cont.

\begin{tabular}{lcc}
\hline & $\begin{array}{c}\text { USGS 9 } \\
\text {-LITH } \\
\text { Se } \boldsymbol{\mu g} / \mathbf{k g}\end{array}$ & $\begin{array}{c}\text { USGS 9 } \\
\mathbf{- 1 0}-\mathbf{f t} \\
\mathbf{S e} \boldsymbol{\mu g} / \mathbf{k g}\end{array}$ \\
\cline { 2 - 3 } Mean & 283 & 477 \\
StdDev & 361 & 543 \\
Median & 110 & 290 \\
Minimum & 0 & 0 \\
Maximum & 1140 & 1520 \\
Count & 12 & 12 \\
CI 95\% & 204 & 307 \\
& & \\
\hline
\end{tabular}

Compare

\section{USGS 9-LITH vs USGS 9 10-ft}

Variance / Mean

$\mathrm{E} / \mathrm{E}$

Critical Values: F $0.05(11,11)=3.47$ and T $0.05(22)=2.074$

Calculated Values: $\mathrm{F}=2.262$ and $\mathrm{T}=1.031$

Calculated values are $<$ critical values

Therefore variances are equal $(\mathrm{E})$ to one another, as are the means 
Table 3. Se concentrations in duplicate samples and replicate analyses of 12 samples coincident to both USGS 9-LITH and USGS 9-10-ft

Three replicate analyses (designated 1,2, and 3) were conducted on each of 3 sub-samples (designated A, B, and C) of 12 samples. The 95 percent confidence interval (CI 95\%) is an estimate of the precision of the mean Se concentration for the analytical method. The CI 95\% divided by the mean is a normalized metric that can be used to compare relative dispersion of the mean, which can be used to compare the precision of Se concentration measurements for samples with differing Se concentrations.

[calculations use data in Appendix B14; StdDev = standard deviation; count $=$ number of analyses; CI 95\% $=95$ percent confidence interval; CI 95\% $\div$ Mean $=$ normalized metric used in this study]

\begin{tabular}{|c|c|c|c|c|c|}
\hline $\begin{array}{l}\text { Sample ID } \\
\text { Interval ft }\end{array}$ & $\begin{array}{c}\text { Mean } \\
\text { Se } \mu \mathrm{g} / \mathrm{kg}\end{array}$ & StdDev & Count & CI 95\% & $\mathrm{Cl} \div$ Mean \\
\hline 163-164 & 453 & 461 & 9 & 301 & 0.66 \\
\hline $170-171$ & 524 & 613 & 9 & 400 & 0.76 \\
\hline $280-281$ & 631 & 515 & 9 & 337 & 0.53 \\
\hline $340-341$ & 149 & 270 & 9 & 176 & 1.18 \\
\hline $390-391$ & 196 & 344 & 9 & 225 & 1.15 \\
\hline $430-431$ & 433 & 628 & 9 & 410 & 0.95 \\
\hline $460-461$ & 269 & 335 & 9 & 219 & 0.81 \\
\hline $560-561$ & 600 & 657 & 9 & 429 & 0.72 \\
\hline $570-571$ & 373 & 437 & 9 & 286 & 0.77 \\
\hline $580-581$ & 329 & 325 & 9 & 212 & 0.65 \\
\hline $600-601$ & 267 & 280 & 9 & 183 & 0.69 \\
\hline \multirow[t]{2}{*}{$650-651$} & 273 & 288 & 9 & 188 & 0.69 \\
\hline & & & & & 0.80 \\
\hline
\end{tabular}


Table 4. A test for stratigraphic variation of Se concentration, comparing the upper stratigraphic interval to the lower stratigraphic interval in each core (USGS 9-LITH, USGS 9-10-ft, USGS 11-10-ft, and USGS 12-10-ft), using univariate statistics and t-test comparisons

In order to compare the equality of the mean Se concentration in two stratigraphic intervals in each core, the variances must first be evaluated for equality with an F-test. Depending on the outcome of the F-test, either the variances are equal (E) or they are unequal (UE). Then a t-test is used to test for equality of the means (using the appropriate t-value for either equal or unequal variances) and determines if the mean Se concentrations in upper and lower stratigraphic intervals are equal (E) or unequal (UE).

For USGS 9-LITH, the mean Se concentration in the upper interval is greater than in the lower interval (variances are unequal to one another and the means are unequal).

For USGS 9-10-ft, the mean Se concentration in the upper interval is greater than in the lower interval (variances are equal to one another whereas the means are unequal).

For USGS 11-10-ft, the mean Se concentration in the upper interval is equal to the mean Se concentration in the lower interval (variances are equal to one another and the means are equal).

For USGS 12-10-ft, the mean Se concentration in the upper interval is equal to the mean Se concentration in the lower interval (variances are equal to one another and the means are equal).

[calculated from data in Appendices B1, B2, B3, and B4 (with Se values below detection limit set = 0); USGS 9-10-ft includes 1-ft samples selected close to coal beds; USGS 9-10-ft lower stratigraphic interval does not include high Se value $6820 \mu \mathrm{g} / \mathrm{kg} ;$ StdDev = standard deviation; CI 95\% = 95 percent confidence interval]

Upper Stratigraphic Interval (below Stockton A to above Chilton A)

\begin{tabular}{|c|c|c|c|c|}
\hline $\begin{array}{c}\text { Core } \\
\text { Interval }\end{array}$ & $\begin{array}{c}\text { USGS 9-LITH } \\
114-446 \mathrm{ft} \\
\text { Se } \mu \mathrm{g} / \mathrm{kg} \\
\end{array}$ & $\begin{array}{c}\text { USGS 9-10-ft } \\
114-446 \mathrm{ft} \\
\text { Se } \mu \mathrm{g} / \mathrm{kg} \\
\end{array}$ & $\begin{array}{c}\text { USGS 11-10-ft } \\
239-652 \mathrm{ft} \\
\text { Se } \mu \mathrm{g} / \mathrm{kg} \\
\end{array}$ & $\begin{array}{c}\text { USGS 12-10-ft } \\
316-492 \mathrm{ft} \\
\text { Se } \mu \mathrm{g} / \mathrm{kg} \\
\end{array}$ \\
\hline Mean & 553 & 666 & 259 & 346 \\
\hline StdDev & 456 & 425 & 327 & 335 \\
\hline Median & 480 & 610 & 119 & 320 \\
\hline Minimum & 0 & 0 & 0 & 0 \\
\hline Maximum & 2440 & 1820 & 1200 & 1060 \\
\hline Count & 46 & 38 & 41 & 17 \\
\hline CI $95 \%$ & 132 & 135 & 100 & 159 \\
\hline \multicolumn{5}{|c|}{ Lower Stratigraphic Interval (below Chilton A to above Fire Clay) } \\
\hline $\begin{array}{l}\text { Core } \\
\text { Interval }\end{array}$ & $\begin{array}{c}\text { USGS 9-LITH } \\
448-690 \mathrm{ft} \\
\text { Se } \mu \mathrm{g} / \mathrm{kg} \\
\end{array}$ & $\begin{array}{c}\text { USGS 9-10-ft } \\
448-690 \mathrm{ft} \\
\text { Se } \mu \mathrm{g} / \mathrm{kg}\end{array}$ & $\begin{array}{c}\text { USGS 11-10-ft } \\
653-828 \mathrm{ft} \\
\text { Se } \mu \mathrm{g} / \mathrm{kg} \\
\end{array}$ & $\begin{array}{c}\text { USGS 12-10-ft } \\
493-625 \mathrm{ft} \\
\text { Se } \mu \mathrm{g} / \mathrm{kg}\end{array}$ \\
\hline Mean & 64 & 329 & 114 & 167 \\
\hline StdDev & 163 & 518 & 203 & 264 \\
\hline Median & 0 & 0 & 0 & 10 \\
\hline Minimum & 0 & 0 & 0 & 0 \\
\hline Maximum & 820 & 1620 & 540 & 740 \\
\hline Count & 53 & 22 & 18 & 12 \\
\hline CI 95\% & 44 & 216 & 94 & 149 \\
\hline
\end{tabular}


Table 4. cont.

\begin{tabular}{cccc}
\hline \multicolumn{4}{c}{ Compare Upper Stratigraphic Interval versus Lower Stratigraphic Interval } \\
$\begin{array}{c}\text { USGS 9-LITH } \\
\text { Upper vs Lower } \\
\text { Variance / Mean }\end{array}$ & $\begin{array}{c}\text { USGS 9-10-ft } \\
\text { Upper vs Lower } \\
\text { Variance / Mean }\end{array}$ & $\begin{array}{c}\text { USGS 11-10-ft } \\
\text { Upper vs Lower } \\
\text { Variance / Mean }\end{array}$ & $\begin{array}{c}\text { USGS 12-10-ft } \\
\text { Upper vs Lower } \\
\text { Variance / Mean }\end{array}$ \\
\hline UE / UE & E / UE & E / E & E / E
\end{tabular}


Table 5. A test for regional variation of Se concentration in each stratigraphic interval (upper and lower) compared among cores, using univariate statistics and t-test comparisons

In order to compare the equality of the mean Se concentration in each stratigraphic interval, the variances must first be evaluated for equality with an F-test. Depending on the outcome of the F-test, either the variances are equal (E) or they are unequal (UE). Then a t-test tests for equality of the means (using the appropriate $t$-value for either equal or unequal variances) and determines if the mean Se concentrations are equal (E) or unequal (UE).

For the upper stratigraphic interval: 1) the mean Se concentration in USGS 9-LITH is equal to the mean Se concentration in USGS 9-10-ft and USGS 12-10-ft (for both comparisons variances are equal to one another and means are equal), and greater than in USGS 11-10-ft (variances are unequal and the means are unequal) 2) the mean Se concentration in USGS 9-10-ft is greater than in USGS 11-10-ft and USGS 12-10-ft (for both comparisons variances are equal to one another and the means are unequal); and 3) the mean Se concentration in USGS 11-10-ft is equal to USGS 12-10-ft (variances are equal to one another and the means are equal).

For the lower stratigraphic interval: 1) the mean Se concentration in USGS 9-LITH is greater than the mean Se concentration in USGS 9-10-ft (the variances are unequal, as well as the means), and is equal to the mean Se concentration in USGS 11-10-ft (variances are equal to one another and means are equal) and USGS 12-10-ft (variances are unequal and the means are equal); 2) the mean Se concentration in USGS 9-10-ft is equal to USGS 11-10-ft and USGS 12-10-ft (for both comparisons variances are unequal to one another and the means are equal); and 3) the mean Se concentration in USGS 11-10-ft is equal to USGS 12-10-ft (variances are equal to one another and the means are equal).

[calculated from data in Appendices B1, B2, B3, and B4 (with Se values below detection limit set = 0); USGS 9-10-ft includes 1-ft samples selected close to coal beds; USGS 9-10-ft lower stratigraphic interval does not include high Se value $6820 \mu \mathrm{g} / \mathrm{kg}$; StdDev = standard deviation; CI 95\% = 95 percent confidence interval]

\begin{tabular}{|c|c|c|c|c|}
\hline $\begin{array}{r}\text { Core } \\
\text { Interval }\end{array}$ & $\begin{array}{c}\text { USGS 9-LITH } \\
114-446 \text { ft } \\
\text { Se } \mu \mathrm{g} / \mathrm{kg} \\
\end{array}$ & $\begin{array}{c}\text { USGS 9-10-ft } \\
114-446 \mathrm{ft} \\
\text { Se } \mu \mathrm{g} / \mathrm{kg} \\
\end{array}$ & $\begin{array}{c}\text { USGS 11-10-ft } \\
239-652 \mathrm{ft} \\
\text { Se } \mu \mathrm{g} / \mathrm{kg} \\
\end{array}$ & $\begin{array}{c}\text { USGS 12-10-ft } \\
316-492 \mathrm{ft} \\
\text { Se } \mu \mathrm{g} / \mathrm{kg} \\
\end{array}$ \\
\hline Mean & 553 & 666 & 259 & 346 \\
\hline StdDev & 456 & 425 & 327 & 335 \\
\hline Median & 480 & 610 & 119 & 320 \\
\hline Minimum & 0 & 0 & 0 & 0 \\
\hline Maximum & 2440 & 1820 & 1200 & 1060 \\
\hline $\begin{array}{l}\text { Count } \\
\text { CI } 95 \%\end{array}$ & 46 & 38 & 41 & 17 \\
\hline Table 5 cont. & 132 & 135 & 100 & 159 \\
\hline
\end{tabular}




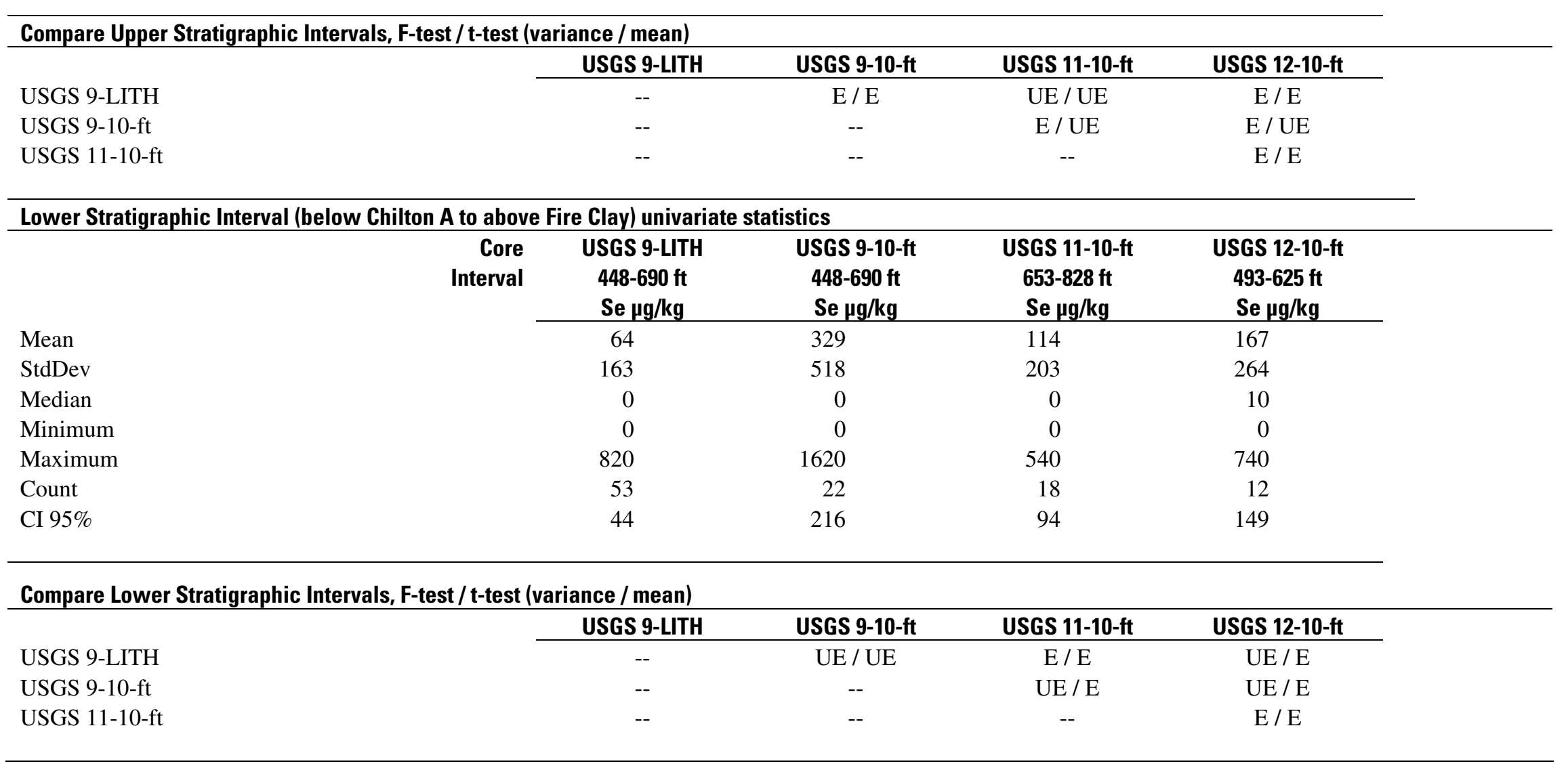


Table 6. Frequency distribution and univariate statistics for Se concentration data in all samples collected at 10-foot intervals in USGS 9-10-ft, USGS 11-10-ft, and USGS 12-10-ft

A. Univariate statistics are calculated for all Se concentrations.

B. Univariate statistics are calculated for Se concentrations without the two highest Se values.

C. Univariate statistics are calculated for Se concentrations without the two highest Se values and replacing 0 values (not detected) with 5 (half the detection limit).

[calculated from data in Appendices B2, B3, and B4 (with Se values below detection limit set $=0$ unless otherwise noted); USGS 9-10-ft includes 1-ft and p-ft samples (see Appendix B2); StdDev = standard deviation; CI 95\% = 95 percent confidence interval]

\begin{tabular}{|c|c|c|c|c|c|}
\hline $\begin{array}{c}\mathrm{Se} \\
\mu \mathrm{g} / \mathrm{kg}\end{array}$ & Frequency & Percent & $\begin{array}{c}\text { Cumulative } \\
\text { Percent }\end{array}$ & & \\
\hline 0 & 78 & 33.1 & 33.1 & & \\
\hline 10 & 2 & 0.8 & 33.9 & \multicolumn{2}{|l|}{ A. All Data } \\
\hline 20 & 5 & 2.1 & 36.0 & & Se $\mu \mathrm{g} / \mathrm{kg}$ \\
\hline 54 & 1 & 0.4 & 36.4 & Mean & 406 \\
\hline 60 & 4 & 1.7 & 38.1 & StdDev & 628 \\
\hline 80 & 2 & 0.8 & 39.0 & Median & 200 \\
\hline 90 & 1 & 0.4 & 39.4 & Minimum & 0 \\
\hline 100 & 6 & 2.5 & 41.9 & Maximum & 6820 \\
\hline 115 & 1 & 0.4 & 42.4 & Count & 236 \\
\hline 119 & 1 & 0.4 & 42.8 & CI $95 \%$ & 80 \\
\hline 120 & 2 & 0.8 & 43.6 & & \\
\hline 124 & 1 & 0.4 & 44.1 & \multicolumn{2}{|c|}{ B. Remove 2 high Se values (6820 and 3300 ) } \\
\hline 140 & 3 & 1.3 & 45.3 & & Se $\mu g / k g$ \\
\hline 160 & 3 & 1.3 & 46.6 & Mean & 366 \\
\hline 180 & 5 & 2.1 & 48.7 & StdDev & 428 \\
\hline 193 & 1 & 0.4 & 49.2 & Median & 200 \\
\hline 200 & 3 & 1.3 & 50.4 & Minimum & 0 \\
\hline 220 & 3 & 1.3 & 51.7 & Maximum & 1840 \\
\hline 233 & 1 & 0.4 & 52.1 & Count & 234 \\
\hline 240 & 1 & 0.4 & 52.5 & CI $95 \%$ & 55 \\
\hline 260 & 1 & 0.4 & 53.0 & & \\
\hline 272 & 1 & 0.4 & 53.4 & \multirow{2}{*}{\multicolumn{2}{|c|}{$\begin{array}{l}\text { C. Remove } 2 \text { high Se values ( } 6820 \text { and } 3300 \text { ) and } \\
\text { change } 0 \text { values to } 5\end{array}$}} \\
\hline 280 & 1 & 0.4 & 53.8 & & \\
\hline 285 & 1 & 0.4 & 54.2 & & Se $\mu \mathrm{g} / \mathrm{kg}$ \\
\hline 300 & 3 & 1.3 & 55.5 & Mean & 368 \\
\hline 320 & 5 & 2.1 & 57.6 & StdDev & 427 \\
\hline 340 & 2 & 0.8 & 58.5 & Median & 200 \\
\hline 355 & 1 & 0.4 & 58.9 & Minimum & 5 \\
\hline 360 & 3 & 1.3 & 60.2 & Maximum & 1840 \\
\hline 371 & 1 & 0.4 & 60.6 & Count & 234 \\
\hline 380 & 1 & 0.4 & 61.0 & CI $95 \%$ & 55 \\
\hline 400 & 6 & 2.5 & 63.6 & & \\
\hline 413 & 1 & 0.4 & 64.0 & & \\
\hline 420 & 1 & 0.4 & 64.4 & & \\
\hline 440 & 2 & 0.8 & 65.3 & & \\
\hline 460 & 2 & 0.8 & 66.1 & & \\
\hline 480 & 3 & 1.3 & 67.4 & & \\
\hline 500 & 2 & 0.8 & 68.2 & & \\
\hline
\end{tabular}




\begin{tabular}{|c|c|c|c|}
\hline 520 & 2 & 0.8 & 69.1 \\
\hline 540 & 2 & 0.8 & 69.9 \\
\hline 560 & 4 & 1.7 & 71.6 \\
\hline 580 & 3 & 1.3 & 72.9 \\
\hline 600 & 5 & 2.1 & 75.0 \\
\hline 620 & 1 & 0.4 & 75.4 \\
\hline 640 & 1 & 0.4 & 75.8 \\
\hline 660 & 4 & 1.7 & 77.5 \\
\hline 680 & 1 & 0.4 & 78.0 \\
\hline 700 & 3 & 1.3 & 79.2 \\
\hline 708 & 1 & 0.4 & 79.7 \\
\hline 720 & 1 & 0.4 & 80.1 \\
\hline 739 & 1 & 0.4 & 80.5 \\
\hline 740 & 3 & 1.3 & 81.8 \\
\hline 760 & 1 & 0.4 & 82.2 \\
\hline 777 & 1 & 0.4 & 82.6 \\
\hline 780 & 1 & 0.4 & 83.1 \\
\hline 800 & 3 & 1.3 & 84.3 \\
\hline 820 & 1 & 0.4 & 84.7 \\
\hline 840 & 2 & 0.8 & 85.6 \\
\hline 860 & 1 & 0.4 & 86.0 \\
\hline 900 & 2 & 0.8 & 86.9 \\
\hline 940 & 2 & 0.8 & 87.7 \\
\hline 960 & 2 & 0.8 & 88.6 \\
\hline 980 & 1 & 0.4 & 89.0 \\
\hline 1000 & 1 & 0.4 & 89.4 \\
\hline 1040 & 3 & 1.3 & 90.7 \\
\hline 1060 & 1 & 0.4 & 91.1 \\
\hline 1080 & 1 & 0.4 & 91.5 \\
\hline 1100 & 1 & 0.4 & 91.9 \\
\hline 1140 & 2 & 0.8 & 92.8 \\
\hline 1200 & 2 & 0.8 & 93.6 \\
\hline 1240 & 2 & 0.8 & 94.5 \\
\hline 1260 & 1 & 0.4 & 94.9 \\
\hline 1320 & 1 & 0.4 & 95.3 \\
\hline 1380 & 1 & 0.4 & 95.8 \\
\hline 1440 & 1 & 0.4 & 96.2 \\
\hline 1500 & 1 & 0.4 & 96.6 \\
\hline 1520 & 2 & 0.8 & 97.5 \\
\hline 1540 & 1 & 0.4 & 97.9 \\
\hline 1620 & 1 & 0.4 & 98.3 \\
\hline 1820 & 1 & 0.4 & 98.7 \\
\hline 1840 & 1 & 0.4 & 99.2 \\
\hline 3300 & 1 & 0.4 & 99.6 \\
\hline 6820 & 1 & 0.4 & 100.0 \\
\hline Total & 236 & 100.0 & \\
\hline
\end{tabular}


Table 7. A test for lithologic variation of Se concentration in four dominant lithologies in USGS 9LITH and USGS 9-10-ft samples, using univariate statistics and t-test comparison

The four dominant lithologies are claystone (CLST), shale (SH), siltstone (SLST), sandstone (SS).

Rank order of means in USGS 9-LITH is SLST $>$ SS $>$ SH $>$ CLST. T-test comparison of mean Se concentrations among lithologies in USGS 9-LITH is as follows: CLST $=\mathrm{SH}, \mathrm{CLST}<\mathrm{SLST}, \mathrm{CLST}<\mathrm{SS}, \mathrm{SH}<\mathrm{SLST}$, SH $<\mathrm{SS}$, $\mathrm{SLST}=$ SS .

Rank order of means in USGS 9-10- $\mathrm{ft}$ is SLST $>$ SS $>$ CLST $>$ SH. T-test comparison of mean Se concentration among lithologies in USGS 9-10-ft is as follows: CLST = SH, CLST < SLST, CLST = SS, SH = SLST, SH = SS, SLST $>$ SS.

[calculated from data in Appendices B1 and B2 (with Se values below detection set = 0); USGS 9-10-ft includes 1-ft samples and does not include high outlier $\mathrm{Se}=6820 \mu \mathrm{g} / \mathrm{kg}$ in a sandstone sample; StdDev = standard deviation; CI $95 \%=95$ percent confidence interval]

\begin{tabular}{|c|c|c|c|c|}
\hline \multicolumn{5}{|c|}{ USGS 9-LITH, univariate statistics } \\
\hline & $\begin{array}{c}\text { Claystone } \\
\text { Se } \mu \mathrm{g} / \mathrm{kg}\end{array}$ & $\begin{array}{c}\text { Shale } \\
\text { Se } \mu g / k g\end{array}$ & $\begin{array}{l}\text { Siltstone } \\
\text { Se } \mu g / k g\end{array}$ & $\begin{array}{c}\text { Sandstone } \\
\text { Se } \mu \mathrm{g} / \mathrm{kg}\end{array}$ \\
\hline Mean & 33 & 65 & 523 & 322 \\
\hline StdDev & 100 & 144 & 605 & 333 \\
\hline Median & 0 & 0 & 400 & 250 \\
\hline Minimum & 0 & 0 & 0 & 0 \\
\hline Maximum & 300 & 540 & 2440 & 1000 \\
\hline Count & 9 & 20 & 23 & 48 \\
\hline \multirow[t]{7}{*}{ CI $95 \%$} & 65 & 63 & 247 & 94 \\
\hline & \multicolumn{4}{|c|}{ USGS 9-LITH, F-test / t-test } \\
\hline & & \multicolumn{3}{|c|}{ Variance / Mean } \\
\hline & & Shale & Siltstone & Sandstone \\
\hline & Claystone & $\mathrm{E} / \mathrm{E}$ & UE / UE & UE / UE \\
\hline & Shale & -- & $\mathrm{UE} / \mathrm{UE}$ & $\mathrm{UE} / \mathrm{UE}$ \\
\hline & Siltstone & -- & -- & $\mathrm{UE} / \mathrm{E}$ \\
\hline
\end{tabular}


Table 7. cont.

USGS 9-10-ft, univariate statistics

\begin{tabular}{|c|c|c|c|c|}
\hline & $\begin{array}{l}\text { Claystone } \\
\text { Se } \mu \mathrm{g} / \mathrm{kg}\end{array}$ & $\begin{array}{c}\text { Shale } \\
\text { Se } \mu g / k g\end{array}$ & $\begin{array}{l}\text { Siltstone } \\
\text { Se } \mu g / k g\end{array}$ & $\begin{array}{c}\text { Sandstone } \\
\text { Se } \mu \mathrm{g} / \mathrm{kg}\end{array}$ \\
\hline Mean & 464 & 405 & 943 & 467 \\
\hline StdDev & 506 & 745 & 547 & 395 \\
\hline Median & 200 & 50 & 740 & 400 \\
\hline Minimum & 0 & 0 & 320 & 0 \\
\hline Maximum & 1320 & 1520 & 1820 & 1620 \\
\hline Count & 10 & 4 & 7 & 52 \\
\hline \multirow[t]{7}{*}{ CI $95 \%$} & 314 & 730 & 405 & 107 \\
\hline & \multicolumn{4}{|c|}{ USGS 9-10-ft, F-test / t-test } \\
\hline & & \multicolumn{3}{|c|}{ Variance / Mean } \\
\hline & & Shale & Siltstone & Sandstone \\
\hline & Claystone & $\mathrm{E} / \mathrm{E}$ & $\mathrm{E} / \mathrm{UE}$ & $\mathrm{E} / \mathrm{E}$ \\
\hline & Shale & -- & $\mathrm{E} / \mathrm{E}$ & $\mathrm{UE} / \mathrm{E}$ \\
\hline & Siltstone & -- & -- & $\mathrm{E} / \mathrm{UE}$ \\
\hline
\end{tabular}


Table 8. A test for lithologic variation of Se concentration in roof, parting, and floor samples from USGS 9, using univariate statistics and t-test comparisons

The means are equal to one another for the 3 sample groups: roof $=$ parting $=$ floor.

[calculated from data in Appendix B9; StdDev = standard deviation; CI 95\% $=95$ percent confidence interval $]$

\begin{tabular}{|c|c|c|c|}
\hline \multicolumn{4}{|c|}{ Univariate Statistics } \\
\hline & $\begin{array}{c}\text { Roof } \\
\text { Se } \mu \mathrm{g} / \mathrm{kg}\end{array}$ & $\begin{array}{l}\text { Parting } \\
\text { Se } \mu g / k g\end{array}$ & $\begin{array}{c}\text { Floor } \\
\text { Se } \mu g / k g\end{array}$ \\
\hline Mean & 798 & 1280 & 922 \\
\hline StdDev & 732 & 649 & 1020 \\
\hline Median & 550 & 1180 & 600 \\
\hline Minimum & 140 & 500 & 0 \\
\hline Maximum & 1940 & 2300 & 3340 \\
\hline Count & 8 & 5 & 13 \\
\hline \multirow[t]{6}{*}{ CI $95 \%$} & 507 & 569 & 555 \\
\hline & F-test / t-test & & \\
\hline & & \multicolumn{2}{|c|}{ Variance / Mean } \\
\hline & & Parting & Floor \\
\hline & Roof & $\mathrm{E} / \mathrm{E}$ & $\mathrm{E} / \mathrm{E}$ \\
\hline & Parting & -- & $\mathrm{E} / \mathrm{E}$ \\
\hline
\end{tabular}


Table 9. Se concentration in USGS 9-RPF (combined roof, parting and floor samples from USGS 9), univariate statistics

[calculated from data in Appendix B9; StdDev = standard deviation; CI $95 \%=95$ percent confidence interval]

\begin{tabular}{lc}
\hline Univariate Statistics & \\
\hline & $\mathbf{R P F}$ \\
& $\mathbf{S e ~} \boldsymbol{\mu g} / \mathbf{k g}$ \\
\cline { 2 - 2 } Mean & 952 \\
StdDev & 864 \\
Median & 660 \\
Minimum & 0 \\
Maximum & 3340 \\
Count & 26 \\
CI 95\% & 332 \\
& \\
\hline
\end{tabular}


Table 10. A test for lithologic variation in Se concentration between USGS 9-RPF, roof, parting, and floor samples and four dominant lithologies in USGS 9-LITH and USGS 9-10-ft samples, using univariate statistics and t-test comparisons

$\mathrm{RPF}=$ combined roof, parting, and floor samples. The four dominant lithologies are claystone $(=$ CLST), shale (= SH), siltstone (= SLST), and sandstone (= SS).

In USGS 9-PRF and USGS 9-LITH, rank order of the mean Se concentrations is RPF $>$ SLST $>$ SS $>$ SH $>$ CLST. T-test comparison of mean Se concentrations among RPF and dominant lithologies in USGS 9-LITH is as follows: RPF $>$ CLST, RPF $>$ SH, RPF $=$ SLST, RPF $>$ SS.

In USGS 9-PRF and USGS 9-10-ft, rank order of the mean Se concentrations is RPF $>$ SLST $>$ SS (without high Se value $=6820 \mu \mathrm{g} / \mathrm{kg}$ ) $>$ CLST $>$ SH. T-test comparison of mean Se concentrations among RPF and dominant lithologies in USGS 9-10-ft is as follows: RPF > CLST, RPF $=$ SH, RPF $=\mathrm{SLST}, \mathrm{RPF}>\mathrm{SS}$.

[calculated from data in tables 7,8 , and 9]

\begin{tabular}{lllll}
\hline \multicolumn{2}{l}{ USGS 9-LITH, F-test / t-test } & \multicolumn{4}{c}{ Variance / Mean } \\
\cline { 2 - 5 } & Claystone & Shale & Siltstone & Sandstone \\
\cline { 2 - 5 } RPF & $\mathrm{UE} / \mathrm{UE}$ & $\mathrm{UE} / \mathrm{UE}$ & $\mathrm{E} / \mathrm{E}$ & $\mathrm{UE} / \mathrm{UE}$ \\
roof & $\mathrm{UE} / \mathrm{UE}$ & $\mathrm{UE} / \mathrm{UE}$ & $\mathrm{E} / \mathrm{E}$ & $\mathrm{UE} / \mathrm{UE}$ \\
parting & $\mathrm{UE} / \mathrm{UE}$ & $\mathrm{UE} / \mathrm{UE}$ & $\mathrm{E} / \mathrm{UE}$ & $\mathrm{UE} / \mathrm{UE}$ \\
floor & $\mathrm{UE} / \mathrm{UE}$ & $\mathrm{UE} / \mathrm{UE}$ & $\mathrm{UE} / \mathrm{E}$ & $\mathrm{UE} / \mathrm{UE}$
\end{tabular}

\begin{tabular}{|c|c|c|c|c|}
\hline \multicolumn{5}{|c|}{ USGS 9-10-ft, F-test / t-test } \\
\hline & \multicolumn{4}{|c|}{ Variance / Mean } \\
\hline & Claystone & Shale & Siltstone & Sandstone \\
\hline RPF & UE / UE & $\mathrm{E} / \mathrm{E}$ & $\mathrm{E} / \mathrm{E}$ & UE / UE \\
\hline roof & $\mathrm{E} / \mathrm{E}$ & $\mathrm{E} / \mathrm{E}$ & $\mathrm{E} / \mathrm{E}$ & $\mathrm{UE} / \mathrm{E}$ \\
\hline parting & $\mathrm{E} / \mathrm{UE}$ & $\mathrm{E} / \mathrm{E}$ & $\mathrm{E} / \mathrm{E}$ & E / UE \\
\hline floor & $\mathrm{UE} / \mathrm{E}$ & $\mathrm{E} / \mathrm{E}$ & $\mathrm{E} / \mathrm{E}$ & UE / UE \\
\hline
\end{tabular}


Table 11. Comparison of Se concentrations $(\mu \mathrm{g} / \mathrm{g}$ or $\mathrm{ppm})$ in various lithologies for published data and data reported in this study

\begin{tabular}{|c|c|c|c|c|}
\hline & $\begin{array}{c}\text { Claystone } \\
\text { Se } \mu \mathrm{g} / \mathrm{g}\end{array}$ & $\begin{array}{c}\text { Shale } \\
\text { Se } \mu \mathrm{g} / \mathrm{g}\end{array}$ & $\begin{array}{c}\text { Siltstone } \\
\text { Se } \mu \mathrm{g} / \mathrm{g}\end{array}$ & $\begin{array}{c}\text { Sandstone } \\
\text { Se } \mu \mathrm{g} / \mathrm{g}\end{array}$ \\
\hline \multicolumn{5}{|c|}{ Horn and Adams (1966), modeled global average } \\
\hline Mean & & 0.60 & & 0.525 \\
\hline Minimum & & 0.3 & & 0.05 \\
\hline Maximum & & 0.9 & & 1.0 \\
\hline \multicolumn{5}{|c|}{ Baedecker and others (1998), western US (see notes below) } \\
\hline Mean & & 2.9 & 2.6 & 1.5 \\
\hline StdDev & & 5.7 & 5.9 & 7.3 \\
\hline Median & & 0.70 & 0.70 & 0.10 \\
\hline Minimum & & 0.05 & 0.10 & 0.05 \\
\hline Maximum & & 34 & 23 & 100 \\
\hline Count & & 247 & 23 & 672 \\
\hline CI $95 \%$ & & 0.72 & 2.4 & 0.56 \\
\hline \multicolumn{5}{|c|}{ Mullennex (2005), 5 cores at a mine site in southwest West Virginia } \\
\hline Mean & & 0.75 & & 0.09 \\
\hline StdDev & & 1.23 & & 0.11 \\
\hline Count & & 102 & & 211 \\
\hline CI $95 \%$ & & 0.24 & & 0.01 \\
\hline \multicolumn{5}{|c|}{$\begin{array}{l}\text { This Study (data from Appendices B2, B3, B4), } 3 \text { cores (USGS 9-10-ft, 11-10-ft, } 12-10-\mathrm{ft} \text { ) from southwest West } \\
\text { Virginia [USGS 9-10-ft includes 1-ft and p-ft samples; does not include two high Se values } 6.82 \text { and } 3.30 \text { ppm } \\
\text { in sandstone] }\end{array}$} \\
\hline Mean & 0.46 & 0.42 & 0.56 & 0.32 \\
\hline StdDev & 0.49 & 0.44 & 0.56 & 0.40 \\
\hline Median & 0.20 & 0.32 & 0.41 & 0.16 \\
\hline Minimum & 0.00 & 0.00 & 0.00 & 0.00 \\
\hline Maximum & 1.32 & 1.52 & 1.82 & 1.84 \\
\hline Count & 15 & 33 & 20 & 166 \\
\hline CI $95 \%$ & 0.25 & 0.15 & 0.25 & 0.06 \\
\hline
\end{tabular}

Data from Baedecker and others (1998):

1) 1439 data points, all shale and sandstone data with Se values

2) Samples are from western US, including Alaska

3) Use Geolex (http://ngmdb.usgs.gov/Geolex/geolex_home.html) to determine usage and age range for given information on Formations

4) Assign dominant lithology and lithologic modifier from Appendix A4.

5) Negative values are 'less than' values.

6) Assign the value $0.05 \mathrm{ppm}$ to all negative Se values (289). $0.05 \mathrm{ppm}$ is the absolute value of half the median value for all 'less than' values. 
Table 11. cont.

Remove 497 samples:

1) Samples with "no information" for Formation (16)

2) Samples with Pre Cambrian for age (217)

3) Samples with ROOF, PART (parting), and SEAT (floor) for lithology associated with coal beds (all 19 samples from Alaska)

4) Samples with ROCK (no specific lithology information), SURF MAT (surface material), PYR (pyrite), BREC (breccia), CGL (conglomerate), LS (limestone), and CLST (claystone) for lithology (87)

5) Samples with lithologic modifier of ORE (ore), U (uranium mineralization), MIN (mineralization, usually sulfate), FEST (ironstone - goethite mineralization), and PYR (pyrite) (158)

The resultant data set, used above, is 942 samples:

857 range in age from Tertiary to Mississippian

85 sandstone samples ( 75 are from Utah) have no age data (no Formation given) 